PLATE I

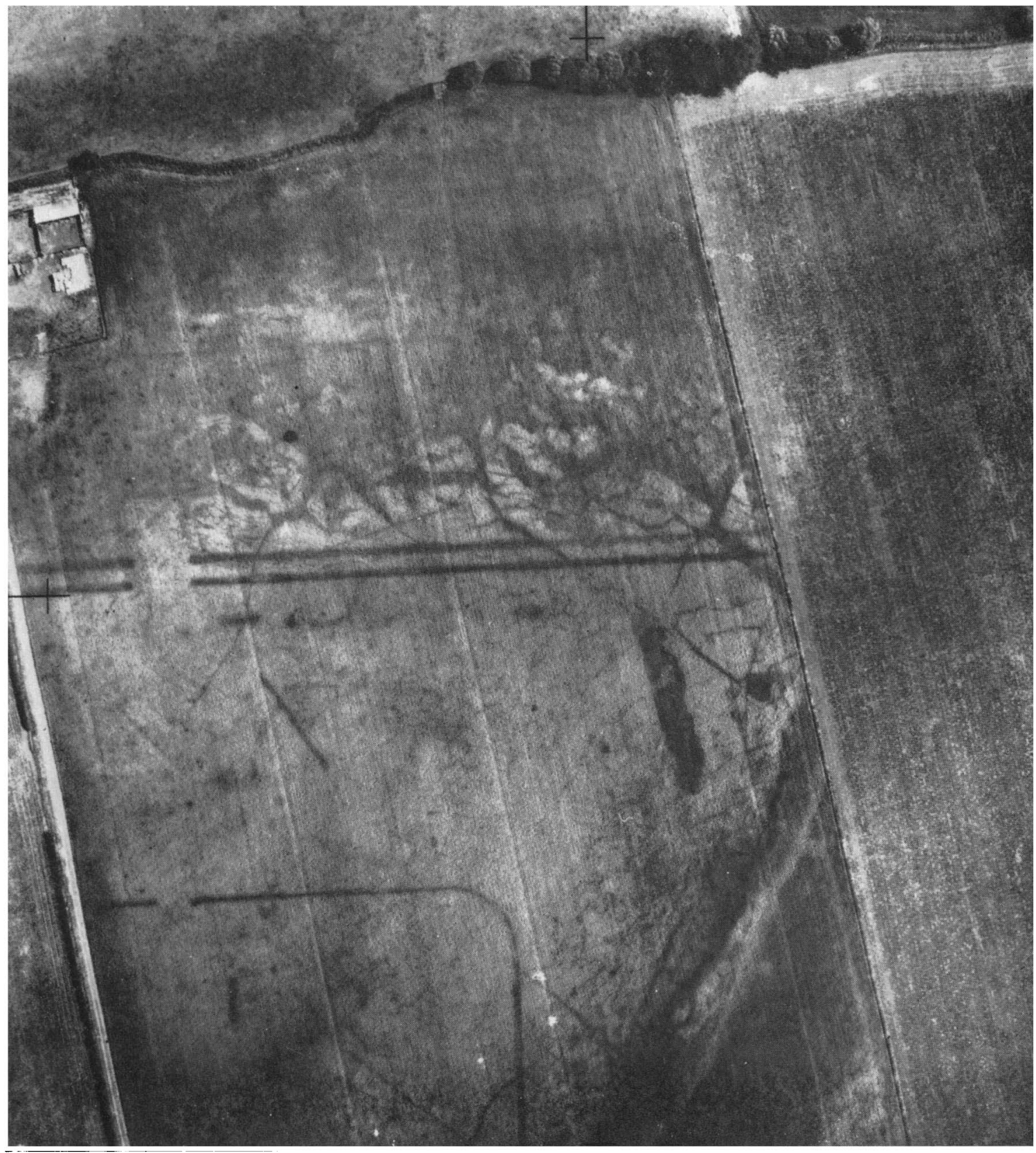

(Photo: Unizersity of Cambridge; copyright reserved)

Longthorpe: vertical photograph of the north-east quarter of the fortress. Scale $c$. $1: 173^{\circ}$ 


\section{PLATE II}

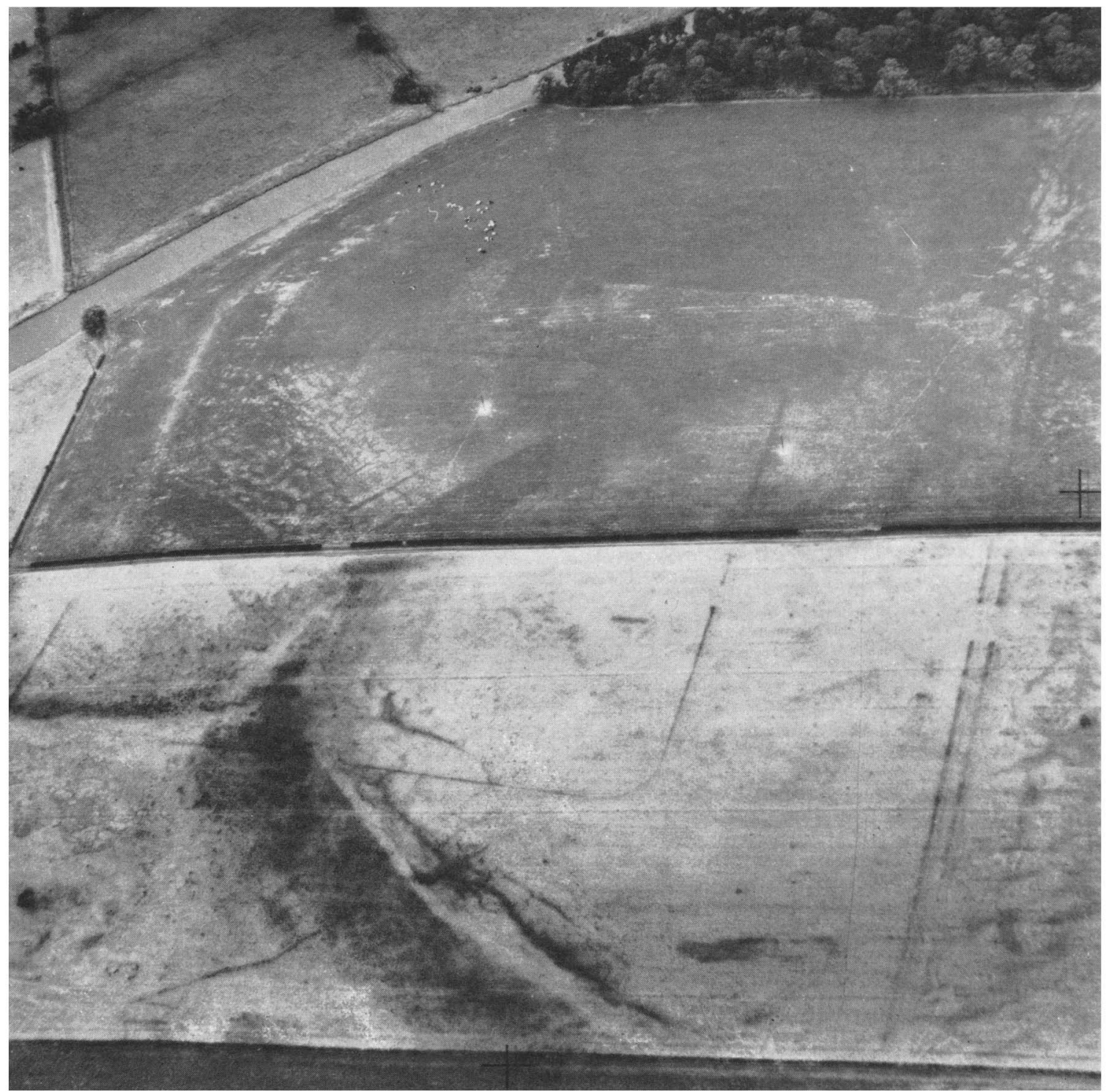

(Photo: University of Cambridge; copyright reserved)

Longthorpe, looking west. The River Nene crosses the top left of the picture, and the dark crop mark of the recent quarry can be seen interrupting the ditch system of Longthorpe I just south of the north-west corner (middle distance, right) (pp. 4, 6). 


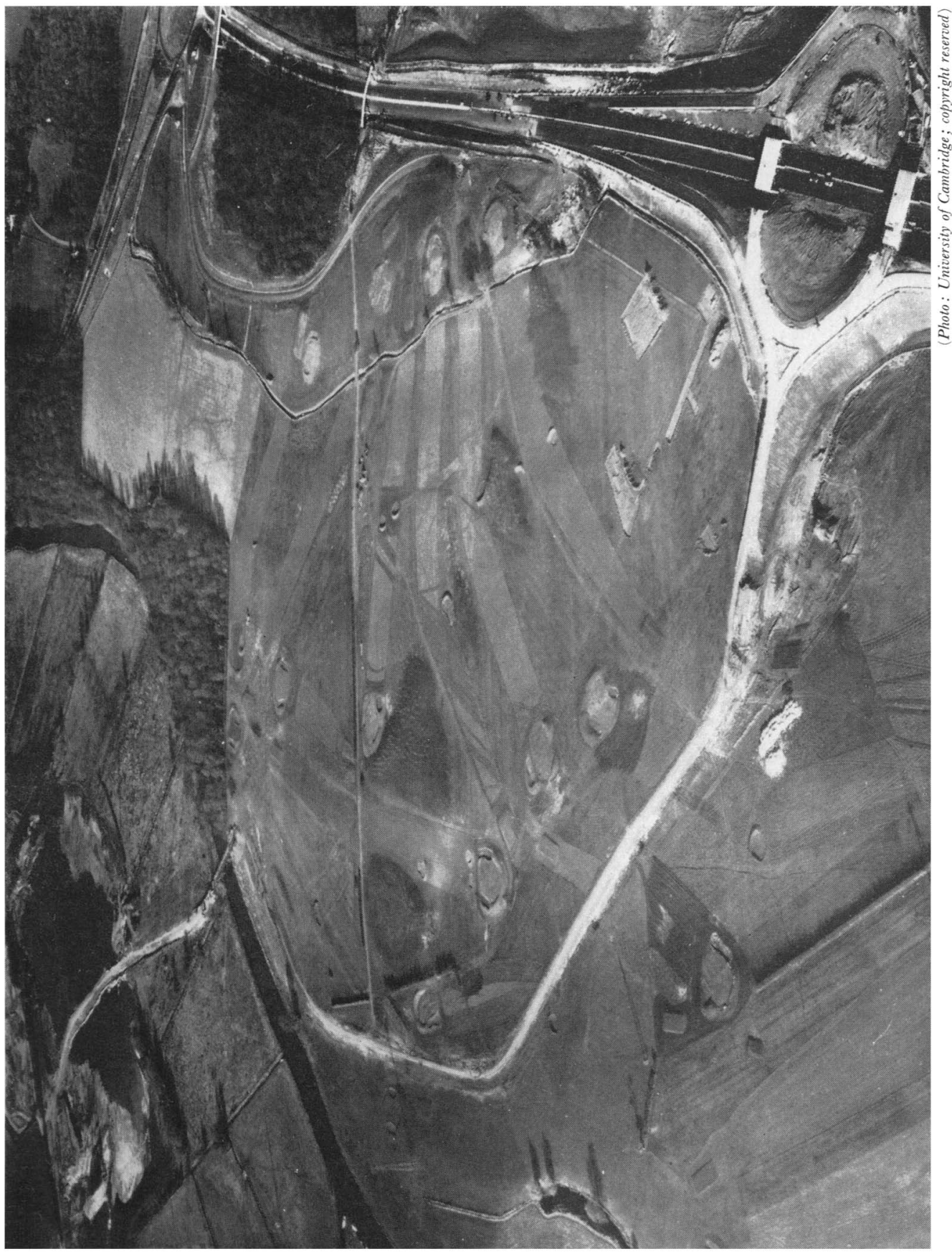

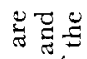

둥

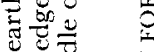

पद

胥

EF

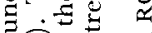

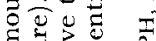

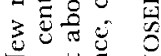

乙心量导?

i

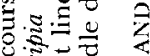

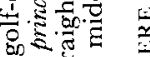

ธะ淧.

รับ

氜

을

$8=\frac{10}{8}$

吅.气

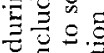

도

๙

동

의월

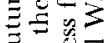

उप)

- क्ष

3 可

我范

청

$\bigcirc$ br.

㱐

융를

范 


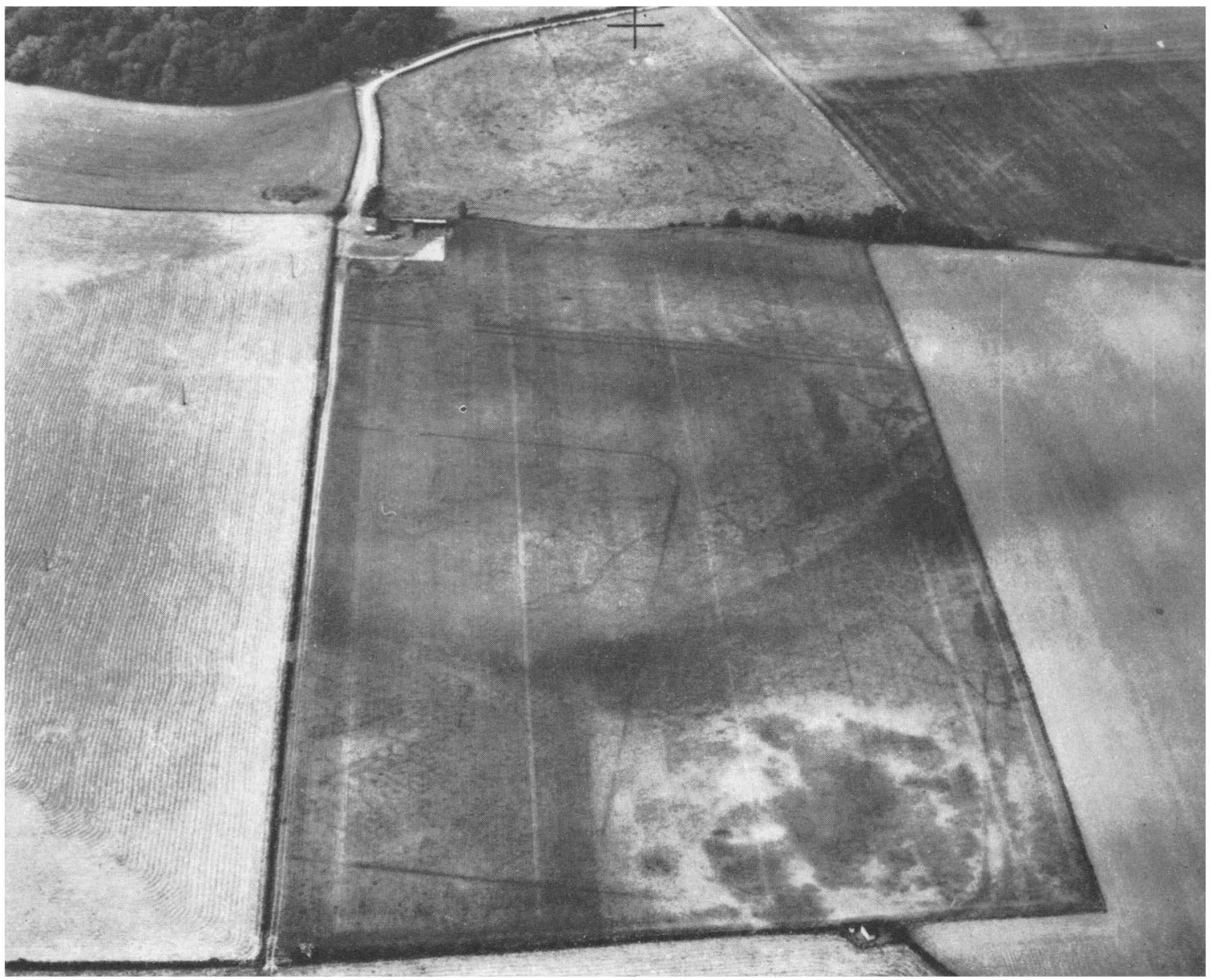

(Photo: University of Cambridge; copyright reserved)

A. Longthorpe, the eastern half of the fortress and fort, looking north. The disturbance of an old quarry occupies the south-east corner of the fortress.

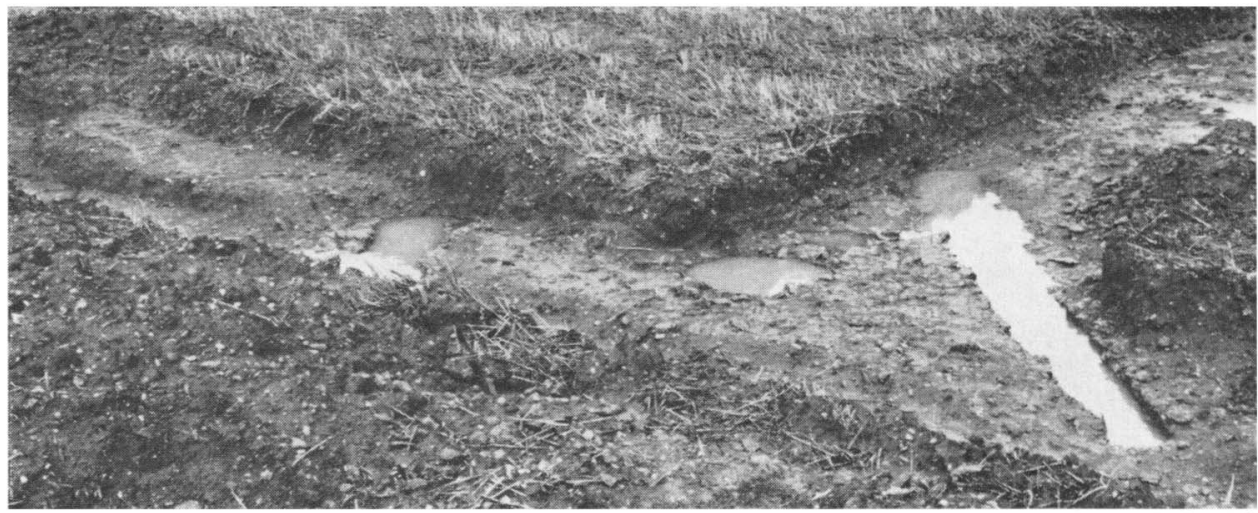

(Photo: S. S. Frere)

B. Longthorpe, Building iii, south-east corner of courtyard looking west, showing shallowness of topsoil and Roman wall-trenches cut in poor-quality rock, and filled with rainwater (pp. 8, 24). 

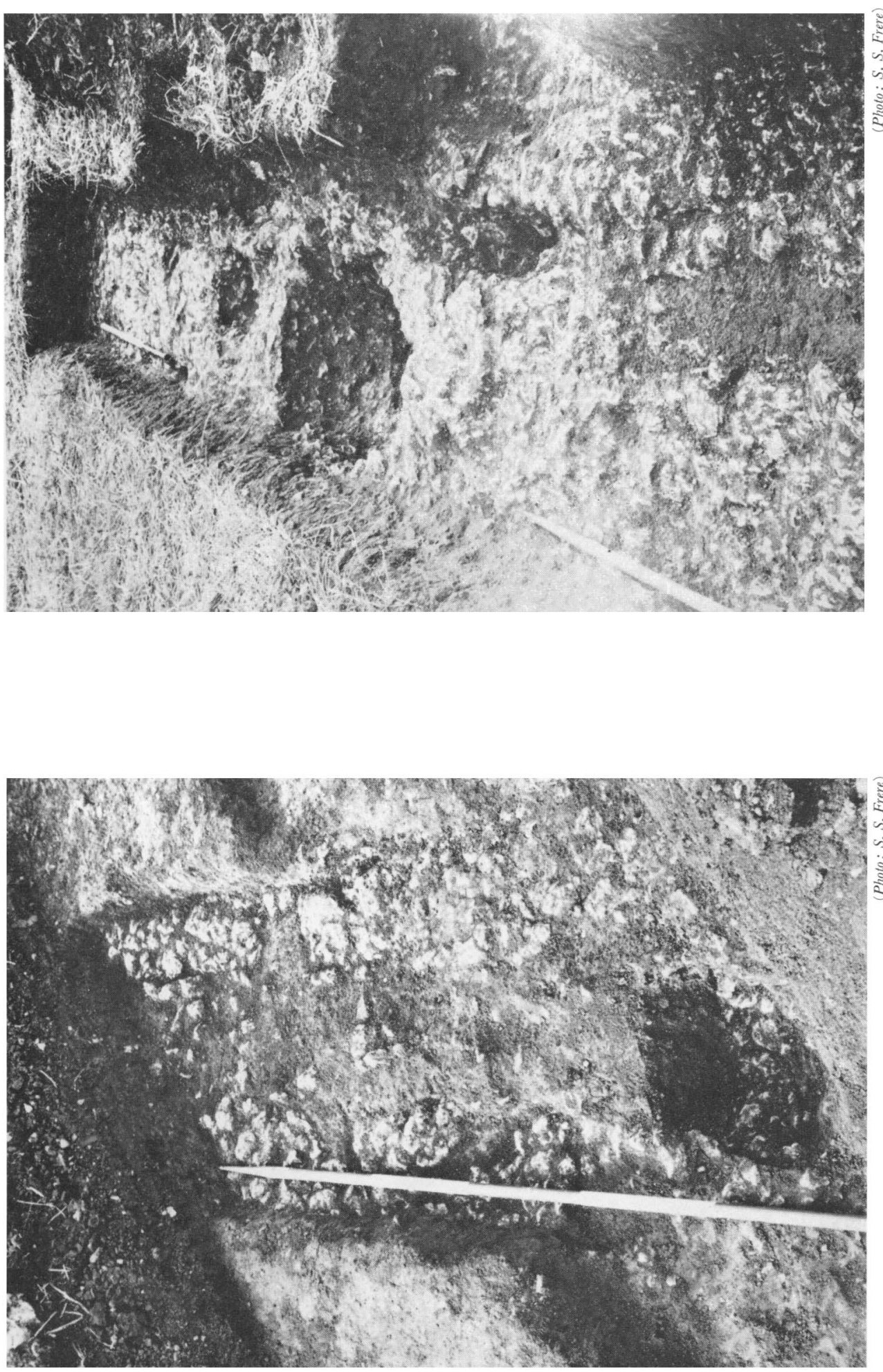


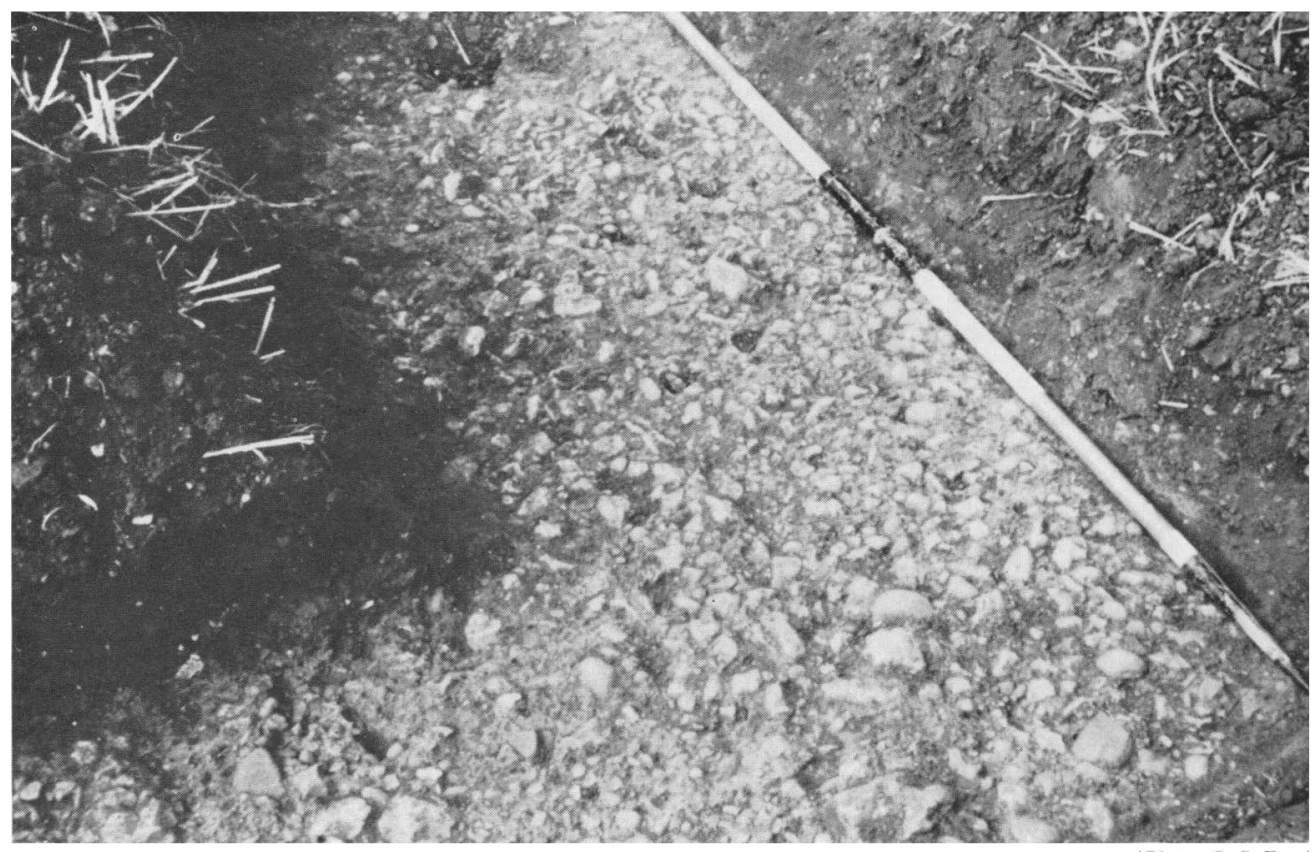

A. Longthorpe, cobbled surface in the principia (p. I9).

(Photo: S. S. Frere)

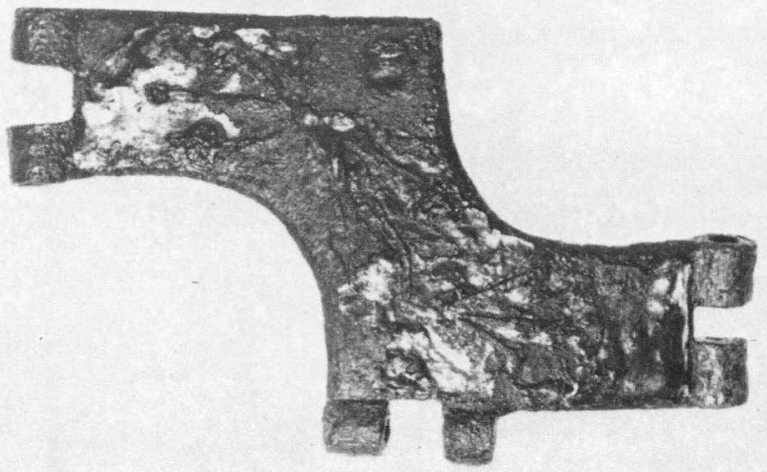

(Photo: R. L. Withini)

B. Longthorpe, hinged bronze plate with silver plating and remains of niello decoration (1) (p. 56 , FIG. 30 , No. 56 ).

BRITANNLA, VOL. V (1974)

FRERE AND ST. JOSEPH, ROMAN FORTRESS AT LOXGTHORPF: 
PLATE VII

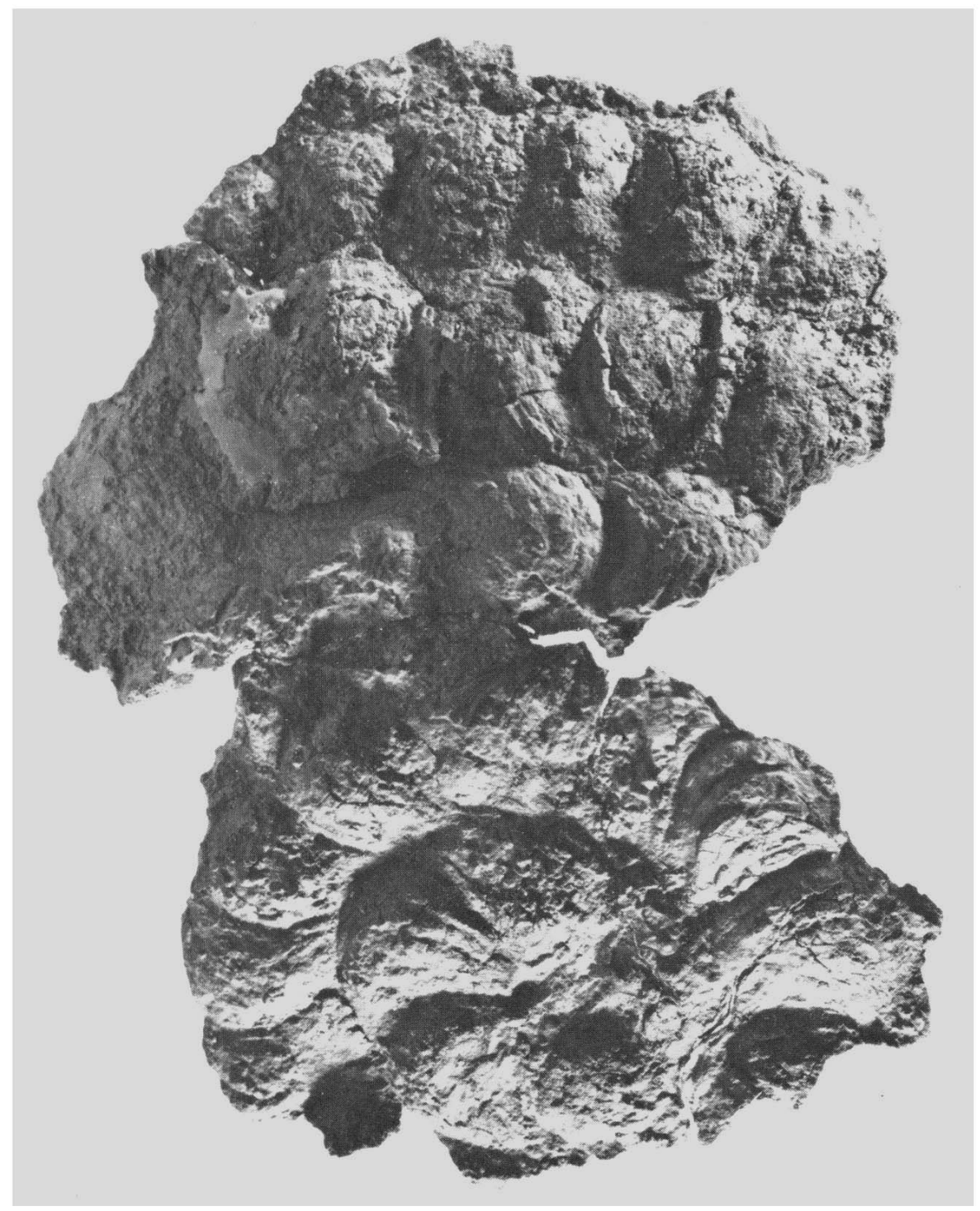

(Photo: R. L. Wilkins)

Longthorpe, crown of cavalryman's iron parade-helmet $\left(\frac{1}{2}\right)$ (p. 74, F1G. 40, No. 2). 


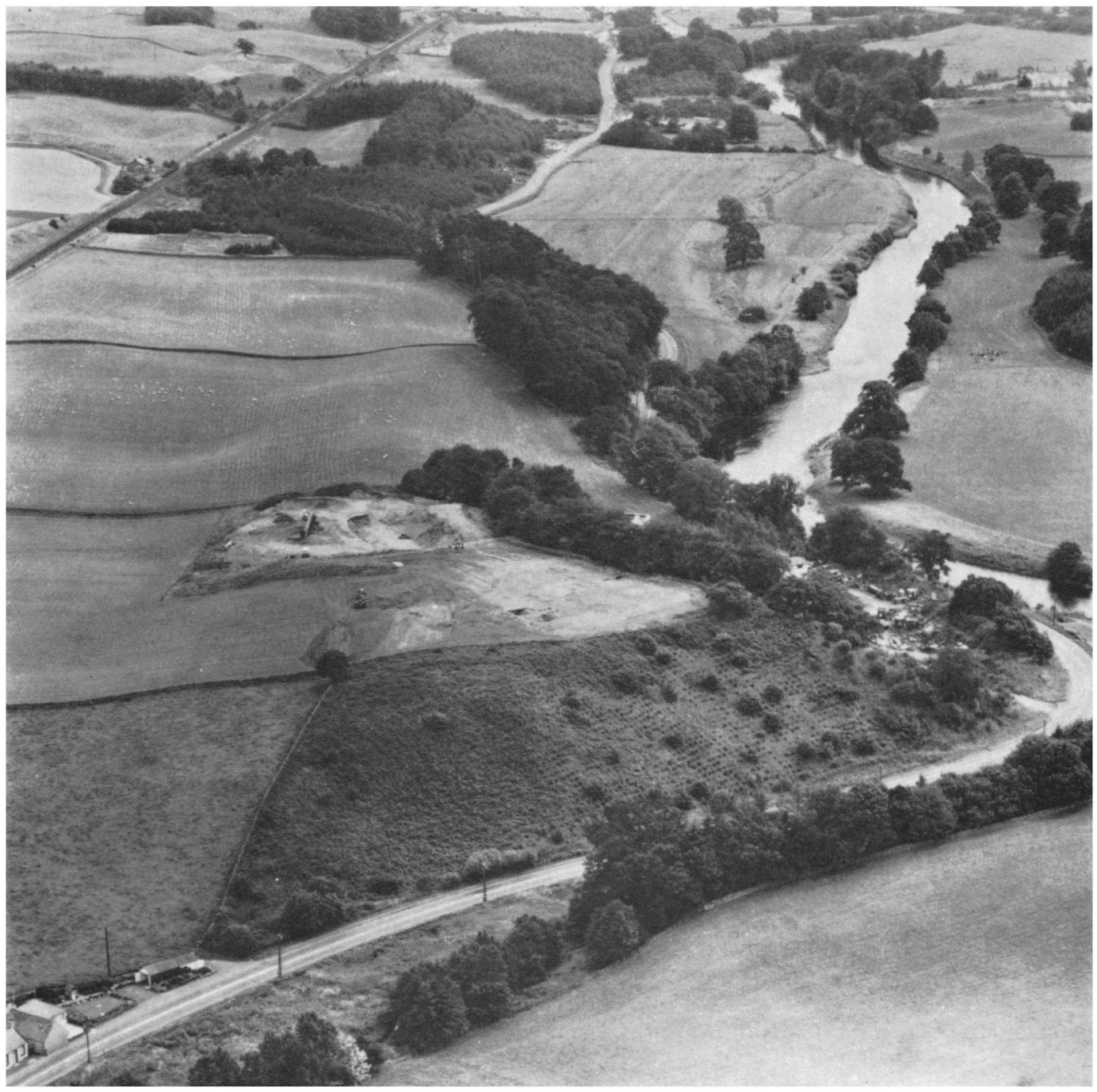

(Photo: 7. Dewar; Crown copyright reserved)

Barburgh Mill: The Nith valley looking south with the fortlet on the hillock in the foreground (p. I30). 


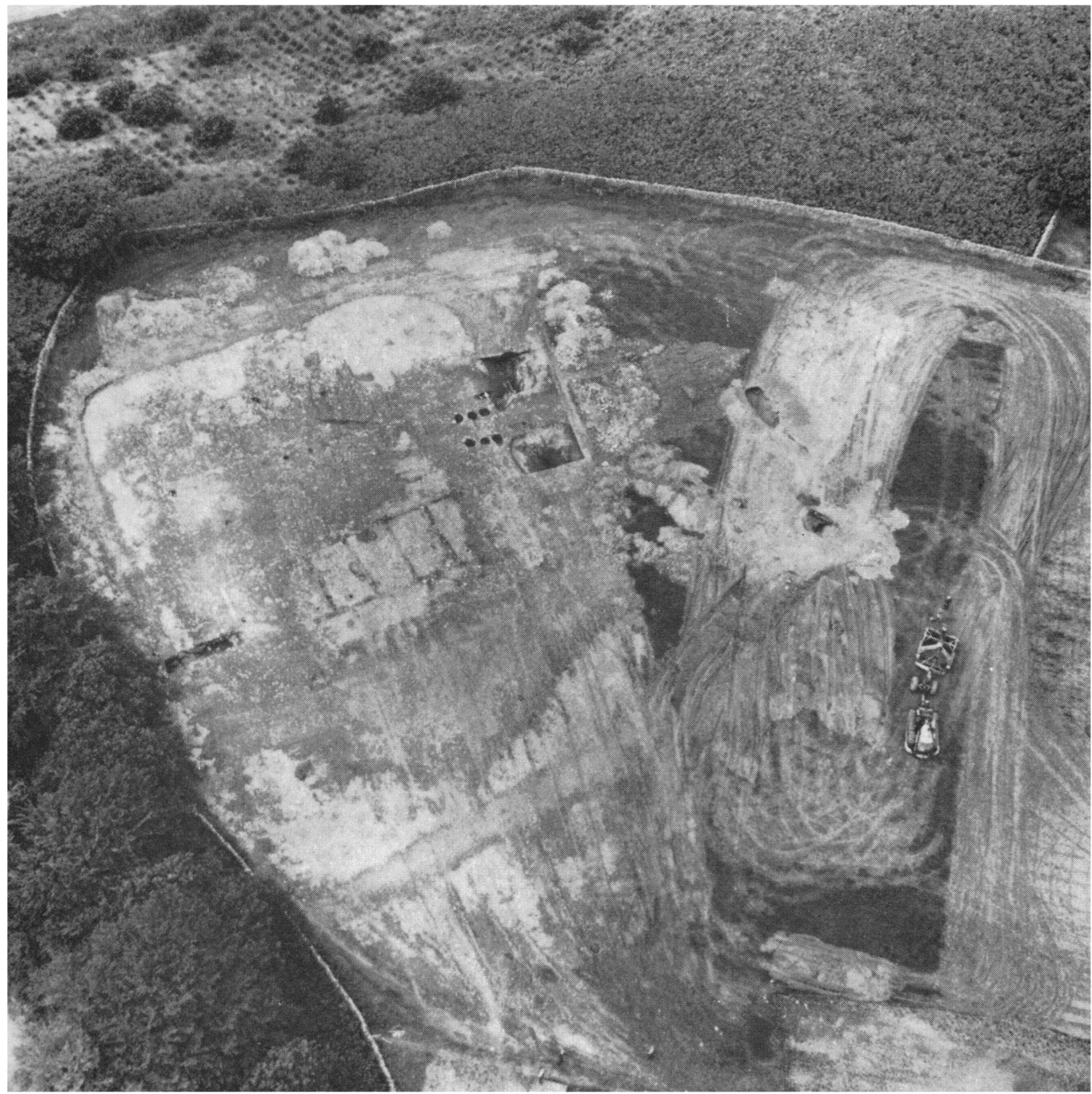

(Photo: 7. Dewar; Crown copyright reserced)

Barburgh Mill: the site, looking north-west. The barrack-blocks are just visible within the fortlet (p. 132). 


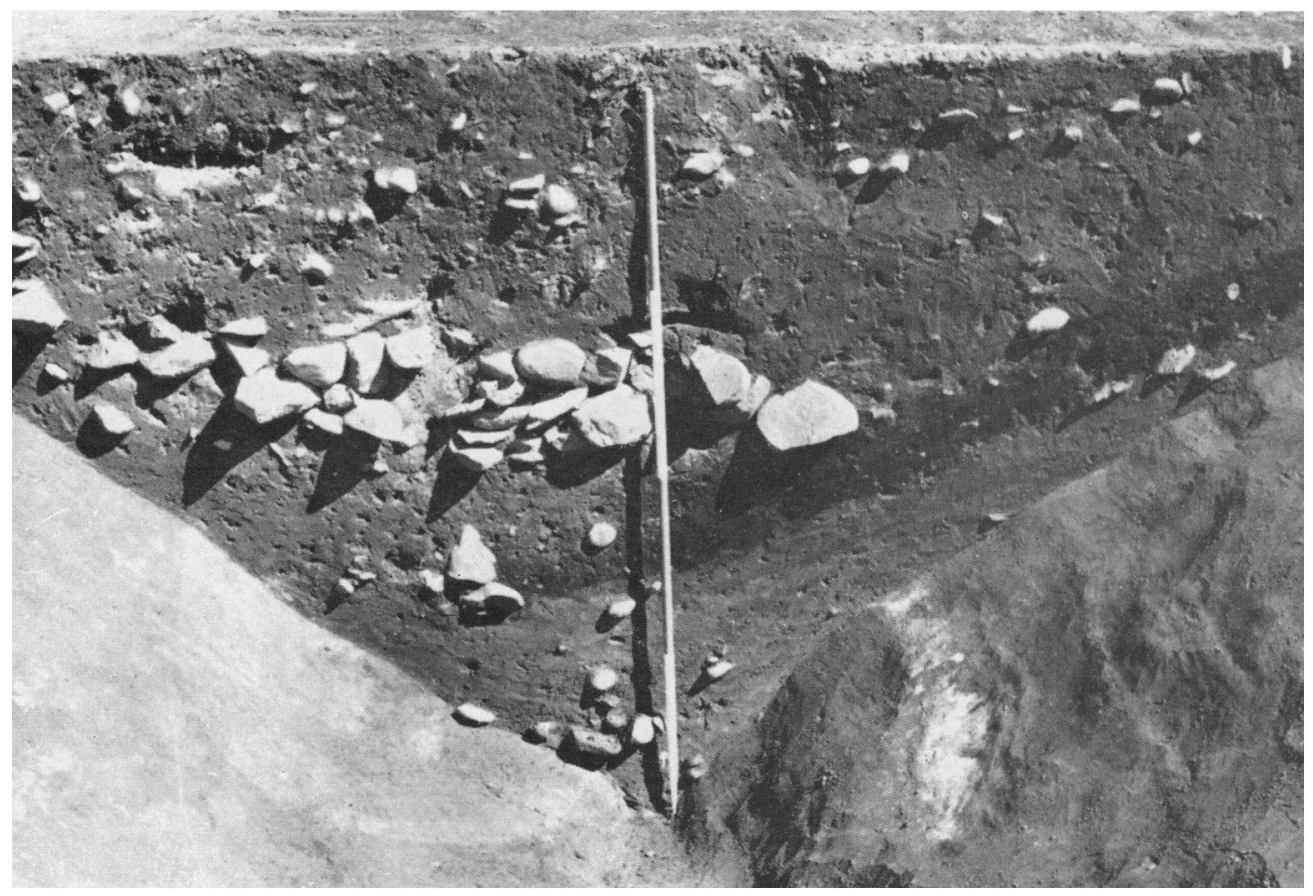

(Photo: R. F. Hhet; (croiem coppright resered)

A. Burburgh Mill: section across the east terminal of the fortlet ditch (p. 137).

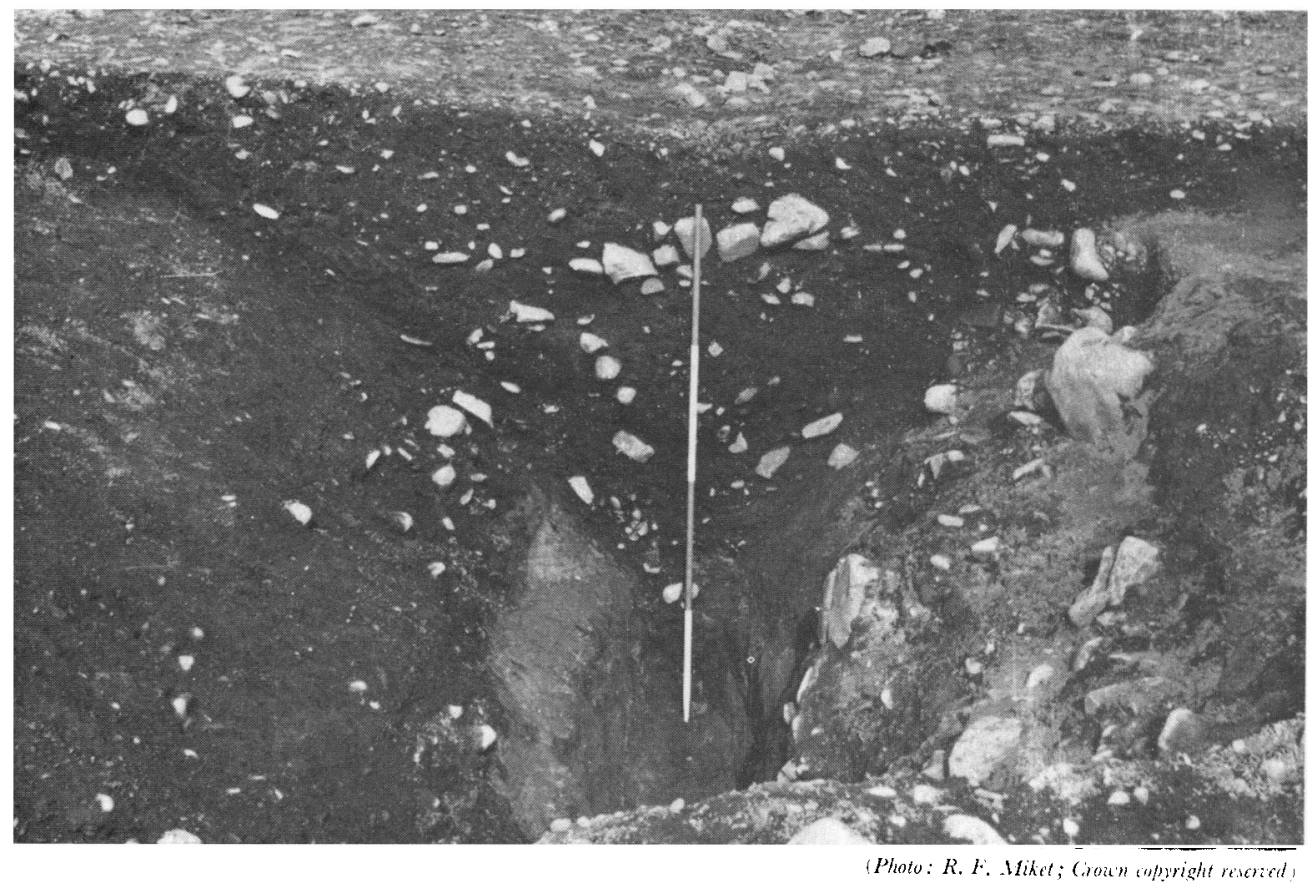

B. Barburgh Mill: section across the west terminal of the fortlet ditch (p. 137). 


\section{PLATE XI}

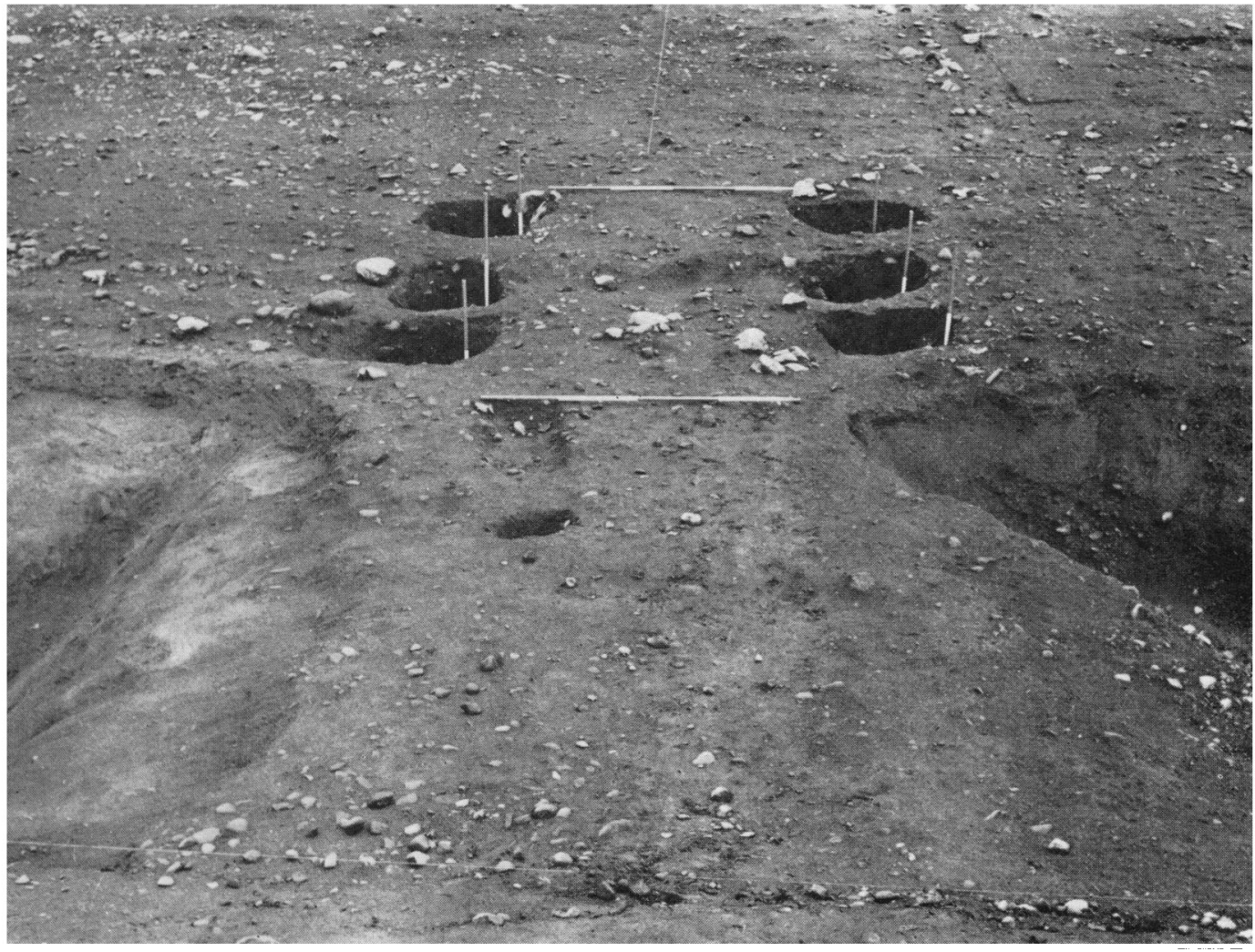

(Photo: R. F. Miket; Crown copyright reserved

A. Barburgh Mill: the gate, looking south into the fortlet. The poles in the post-pits mark the position of the timbers (p. 132).

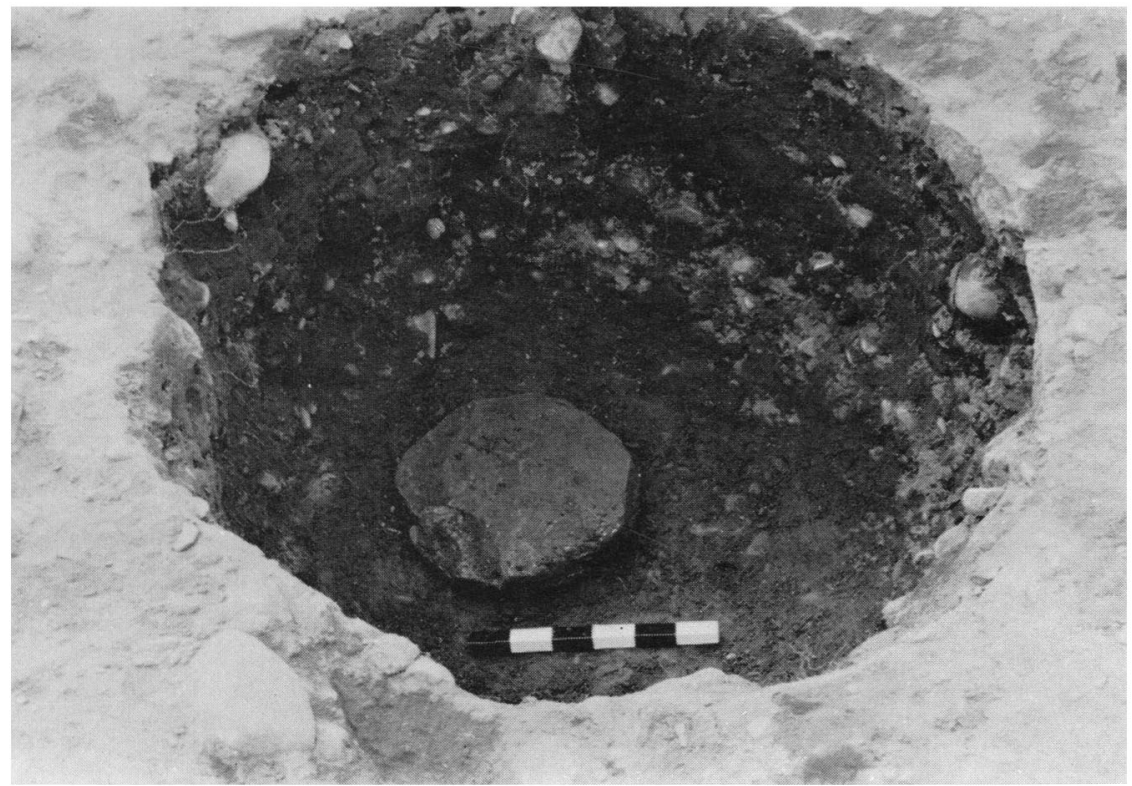

(Photo: R. F. Miket; Crown copyright reserved)

B. Barburgh Mill. Central post-pit on west side of gate, showing the stone on which the timber rested (p. 135). BRITANIIA, VOL. V (1974) 


\section{PLATE XII}

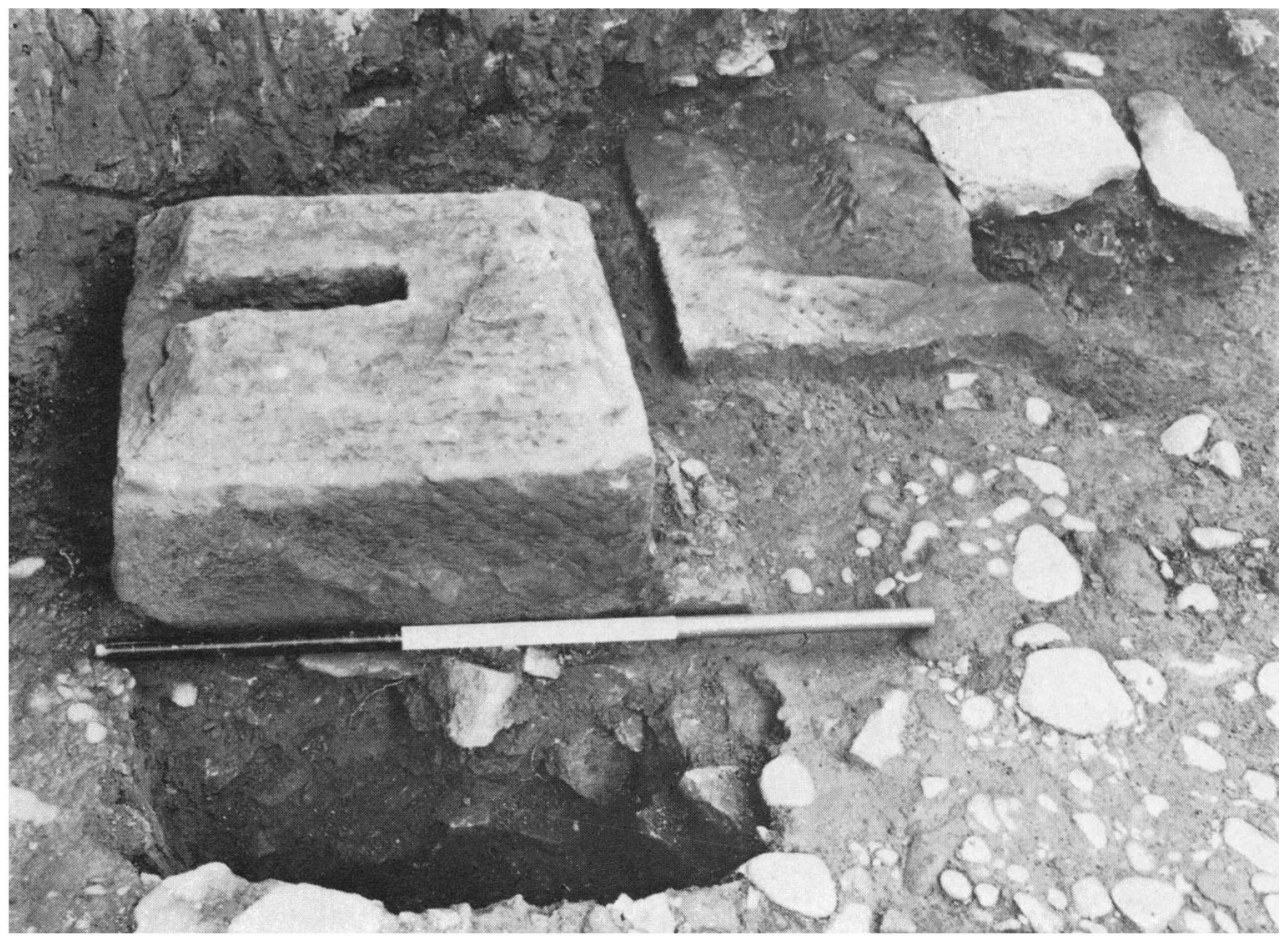

(Ptoto; RCAHM, Solland; copyright reserved

A. Cramond. Column-base and gutter of portico in the princifica (p. 178 ).

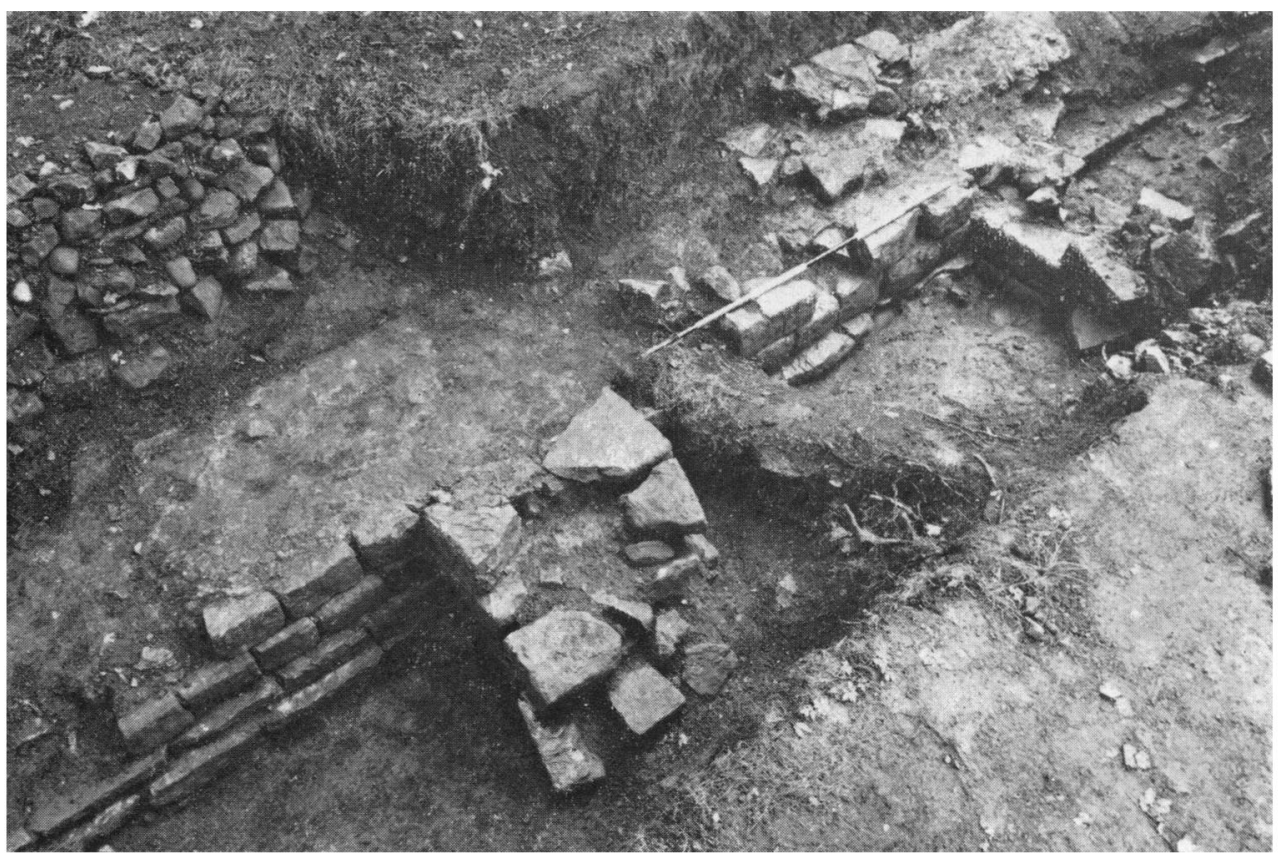

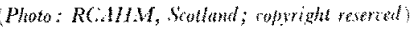

B. Cramond. Buttresses on the west wall of the storehouse (p. 178). 


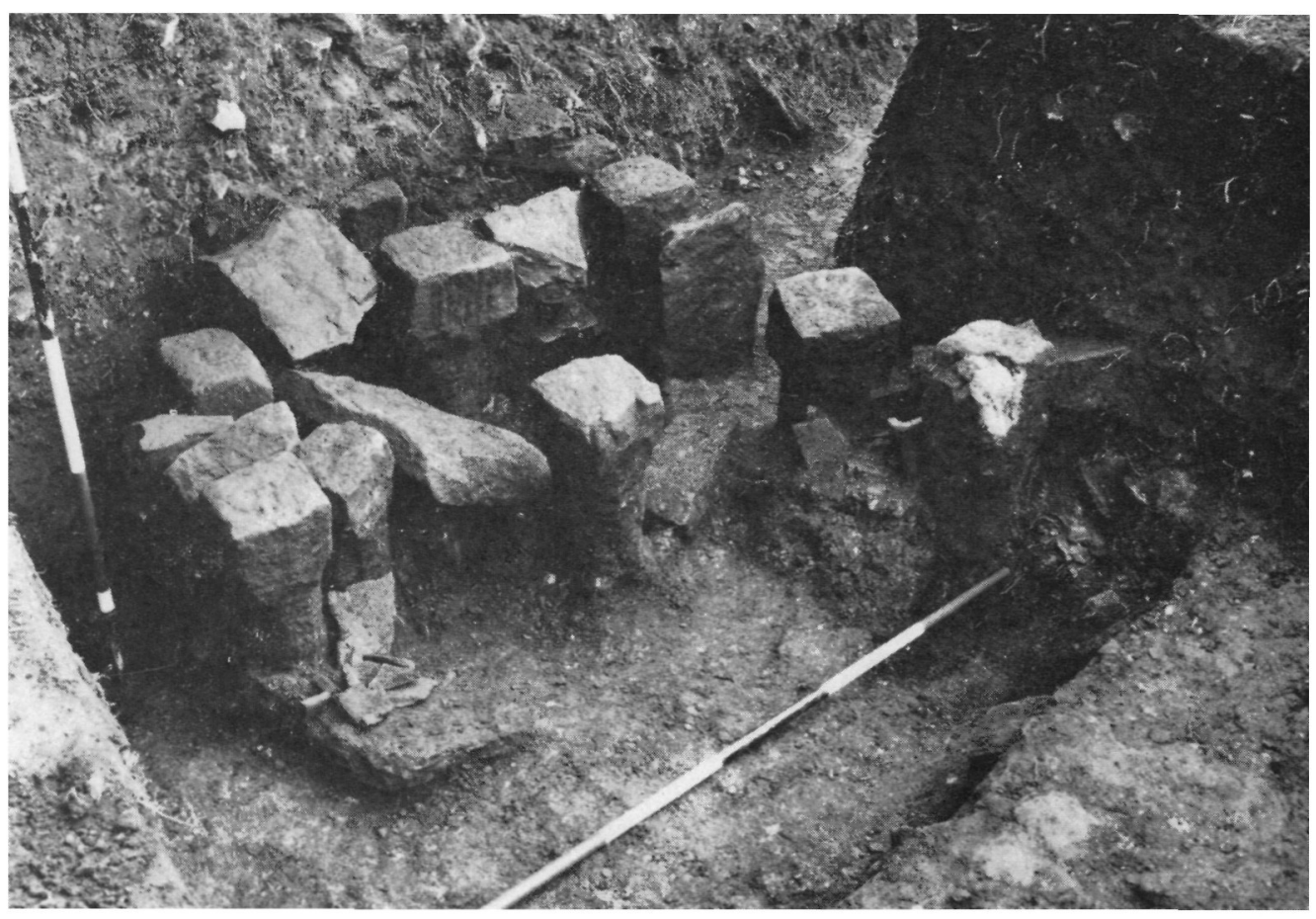

(Photo: RCAHM, Scotland; copyright reserved)

A. Cramond. Part of hypocausted structure in west praetentura (p. I88).

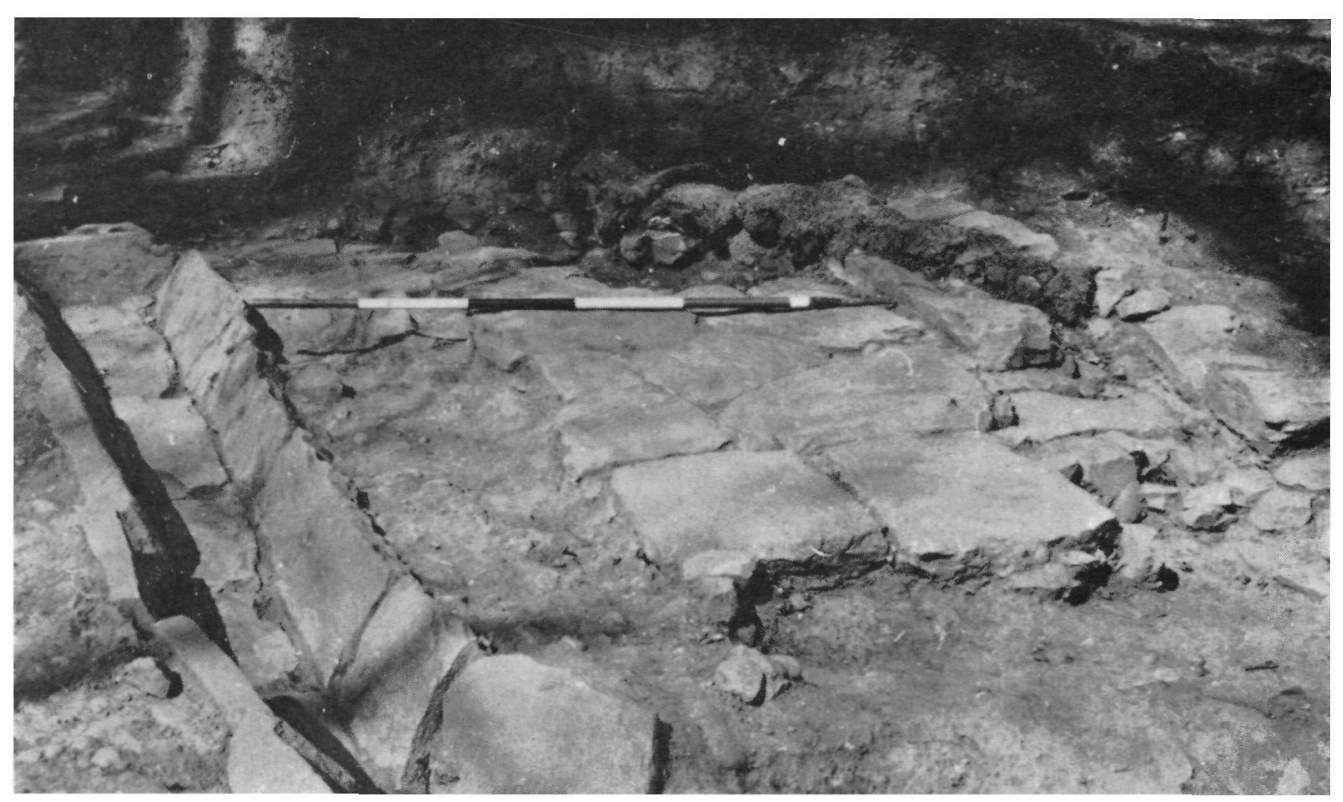

(Photo: RCAHM, Scotland; copyright reserved)

B. Cramond. View of latrine in north-west angle of fort (p. 187). 


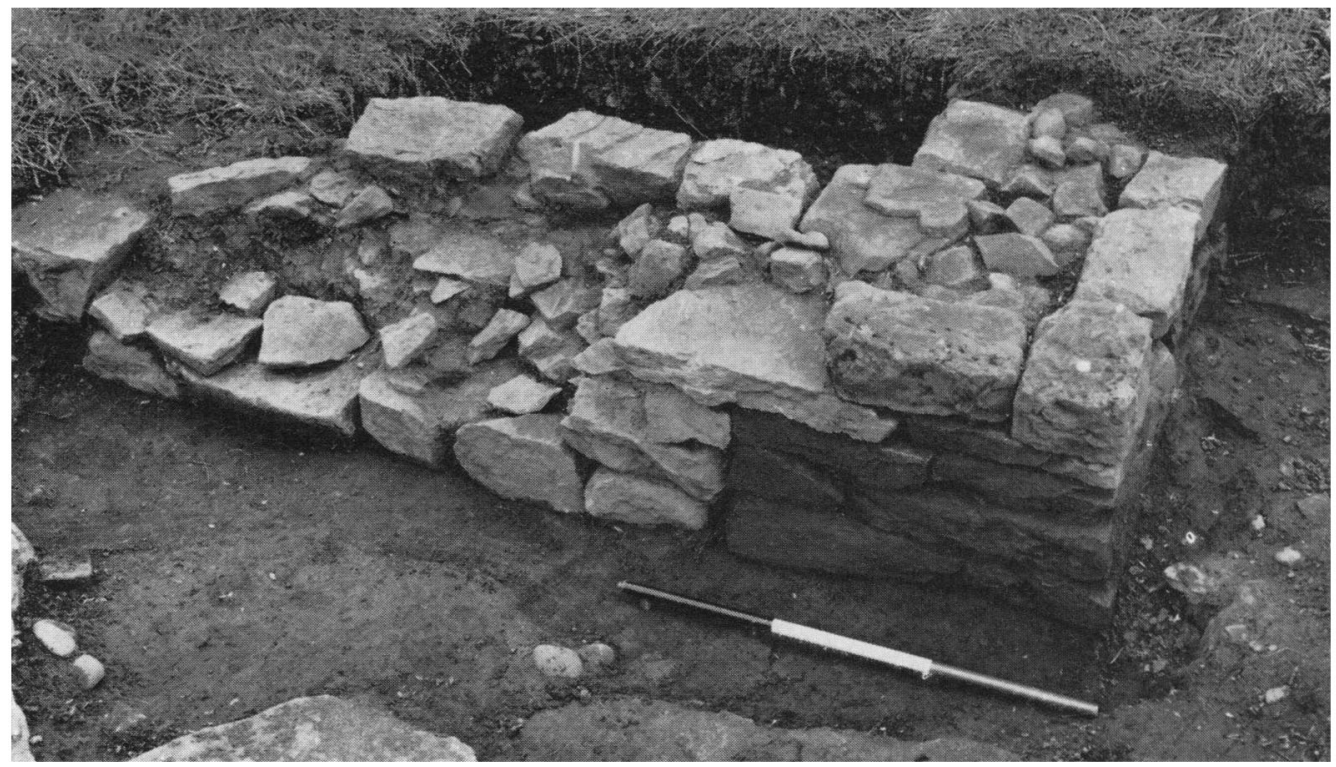

(Photo: RCAHM, Scotland; copyright reserved)

A. Cramond. South-east corner of Block $A$, showing masonry of two periods (p. I 86).

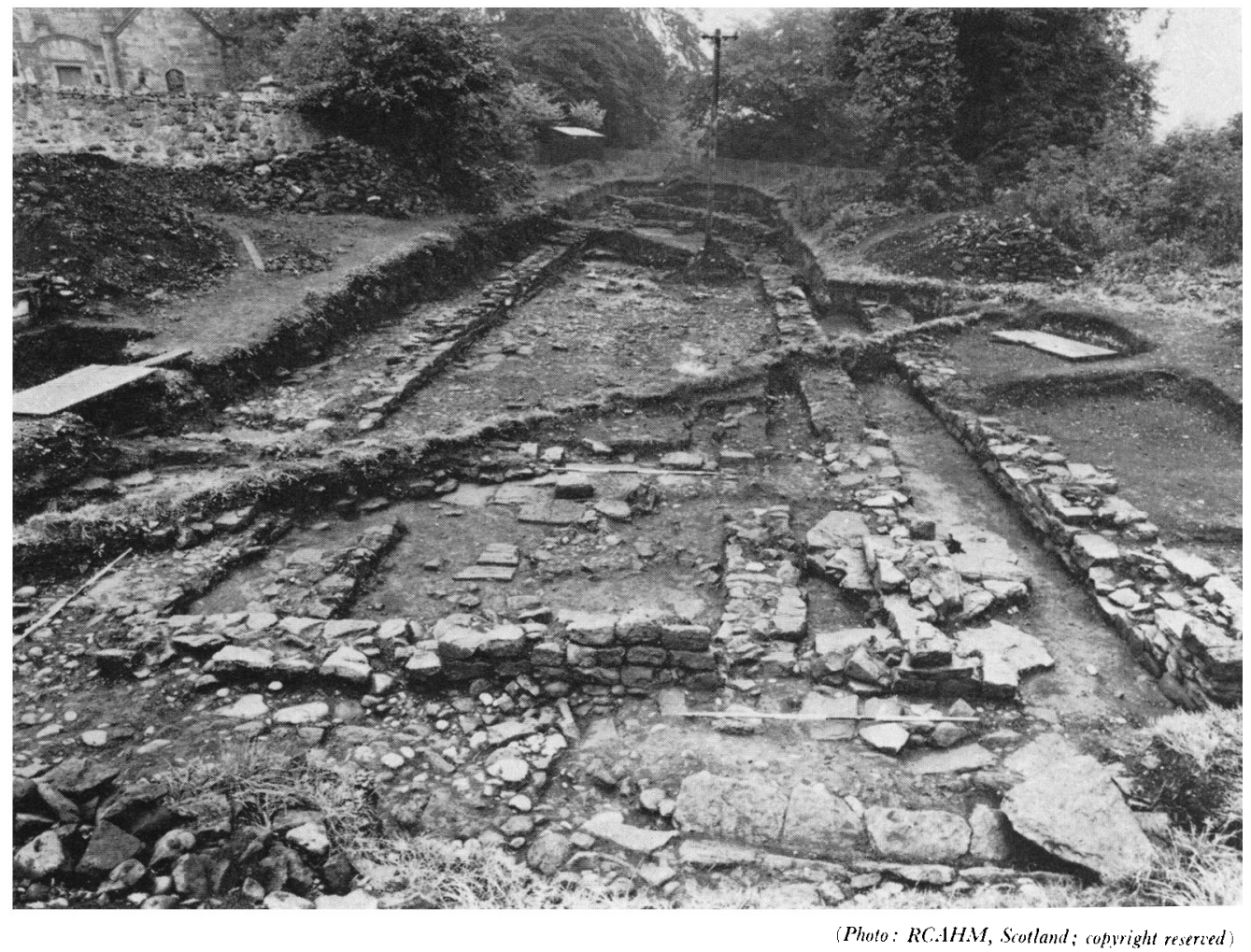

B. Cramond: Block B; general view from east (p. 181). 


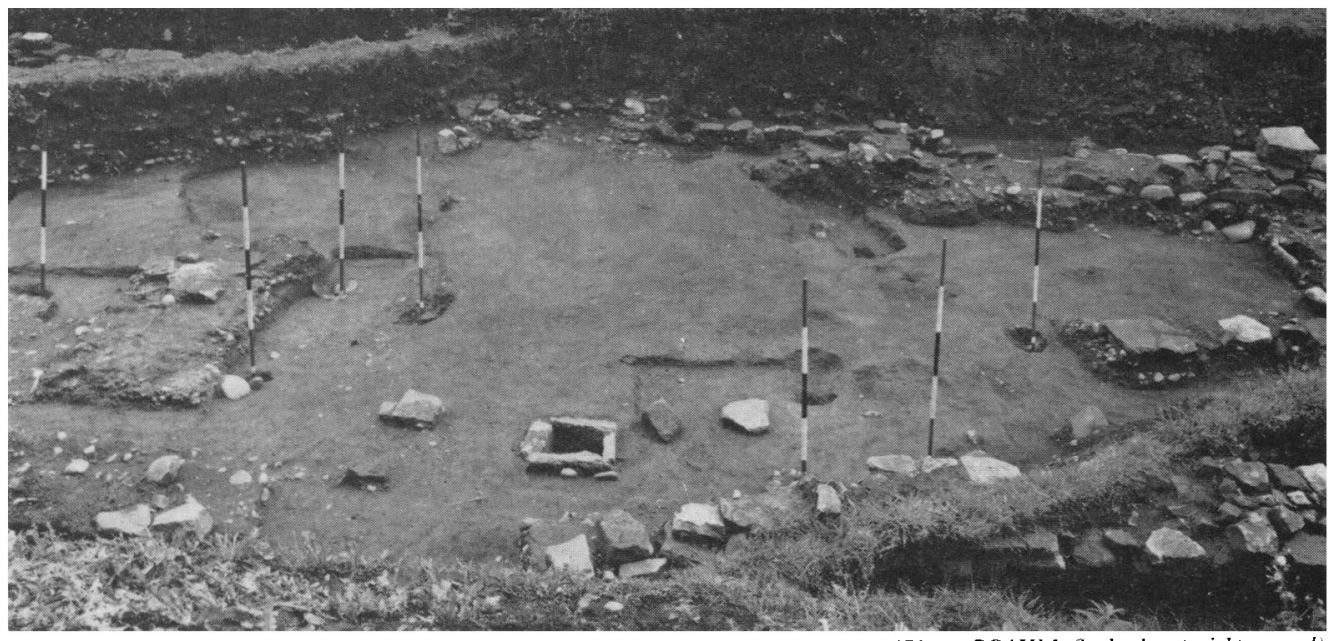

(Photo: RCAHM, Scotland ; copyright reserved)

A. Cramond. Block B; central area. looking south (p. 181).

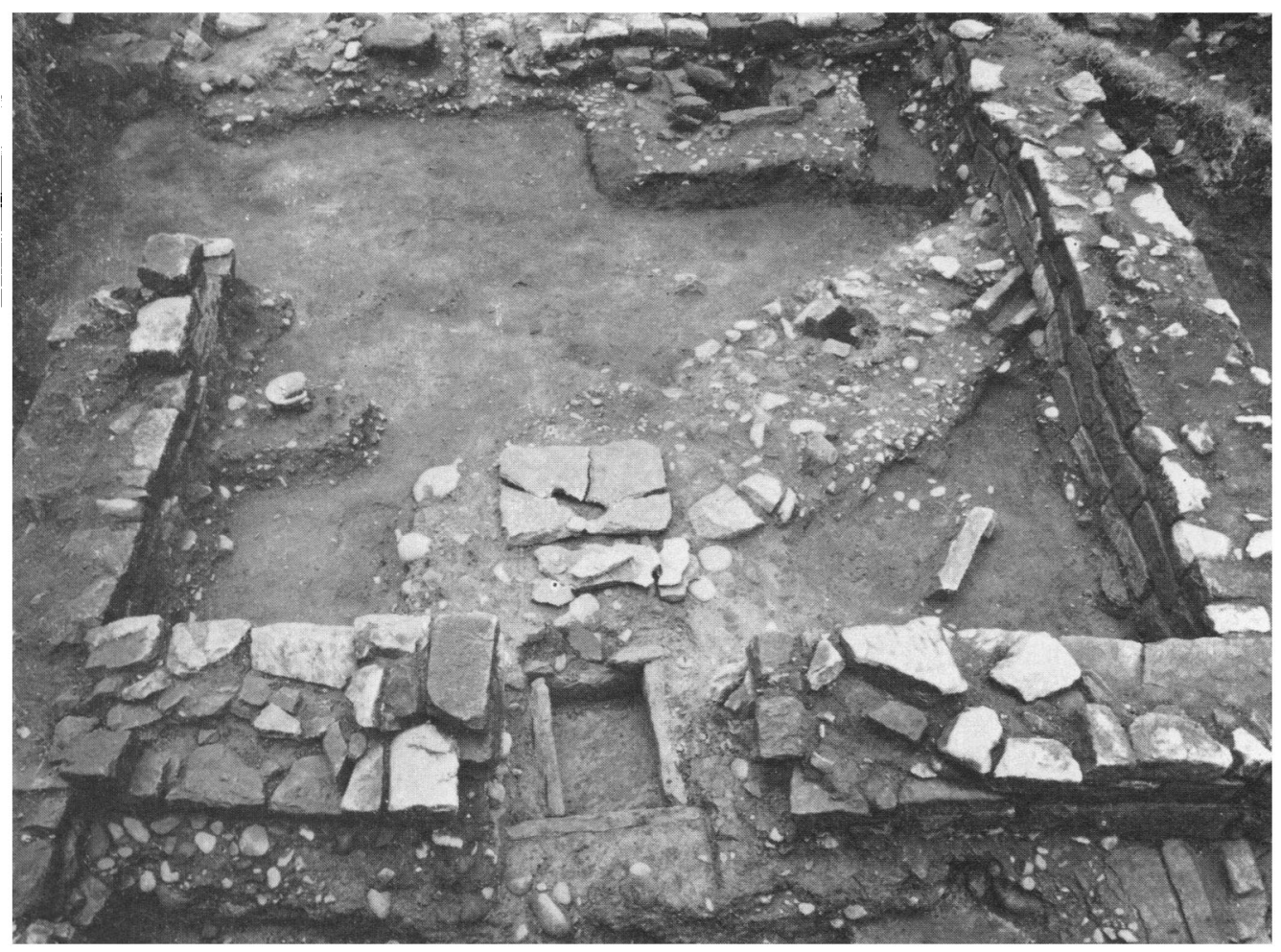

(Photo: RCAHM, Scotland; copyright reserved)

B. Cramond. Block B; west end, showing tank beneath entrance (p. 185). 


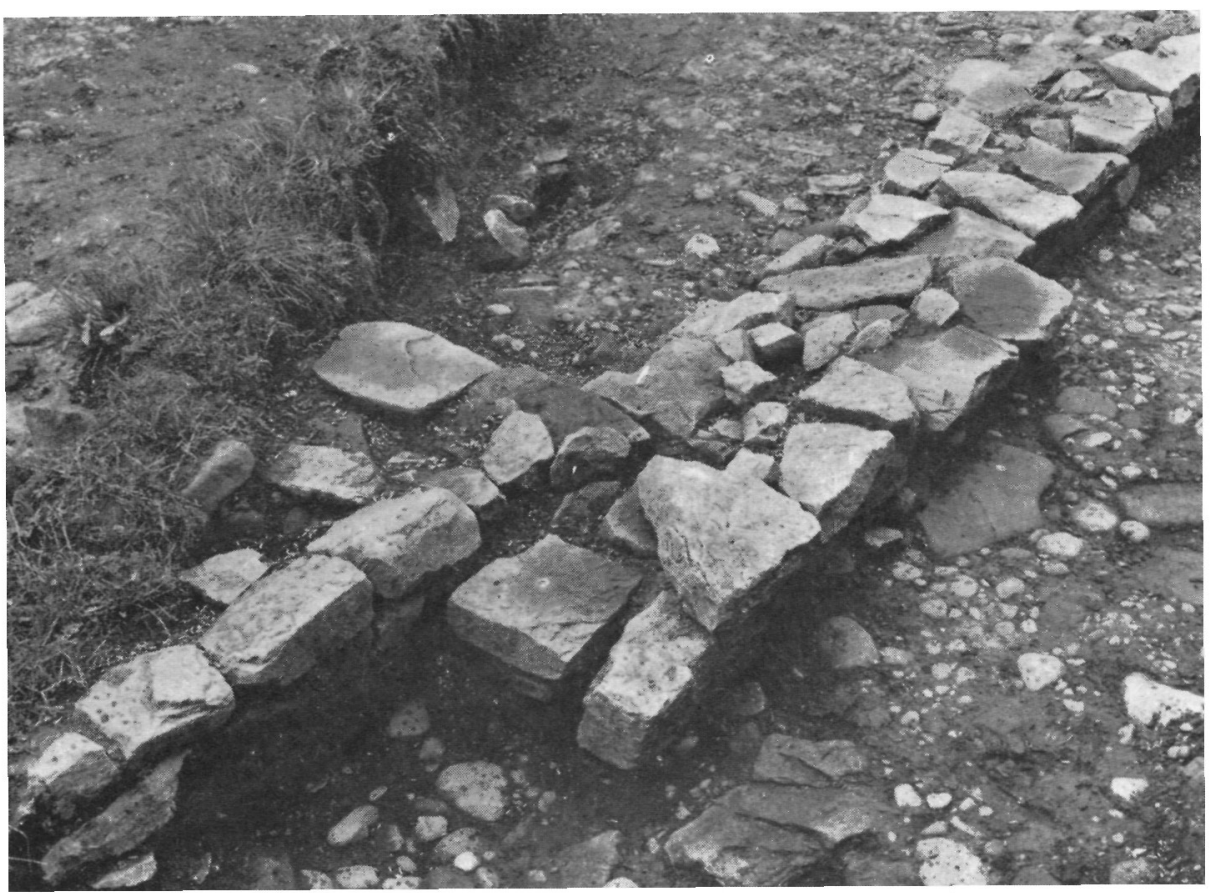

(Photo: RCAHM, Scotland; copyright reserved)

A. Cramond. Westernmost entrance in south wall of Block B, showing blocking (p. 184).

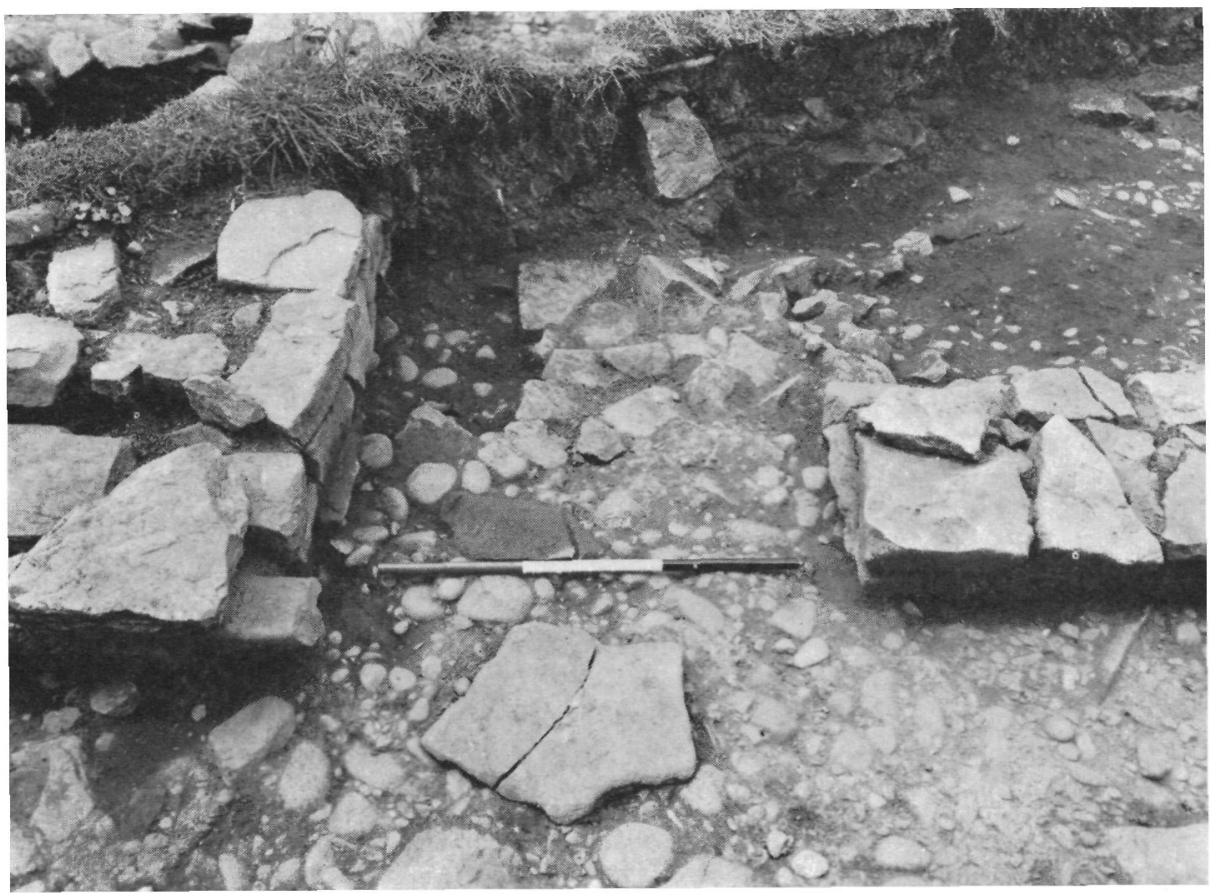

(Photo: RCAHM, Scotland; copyright reserved)

B. Cramond. Westernmost entrance of Block B with blocking removed (p. 184). 


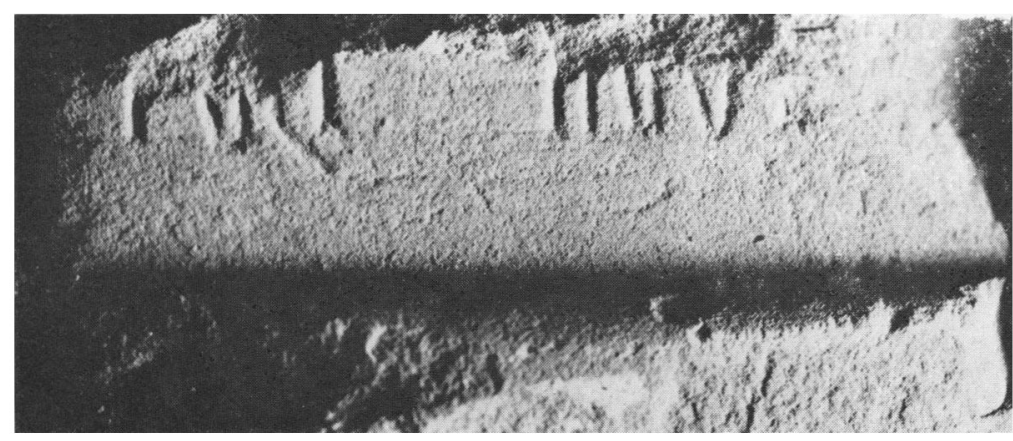

(Photo: RCAHM, Scolland; c)pyright reserced)

A. Cramond. The altar base with fragmentary inscription (p. 196).

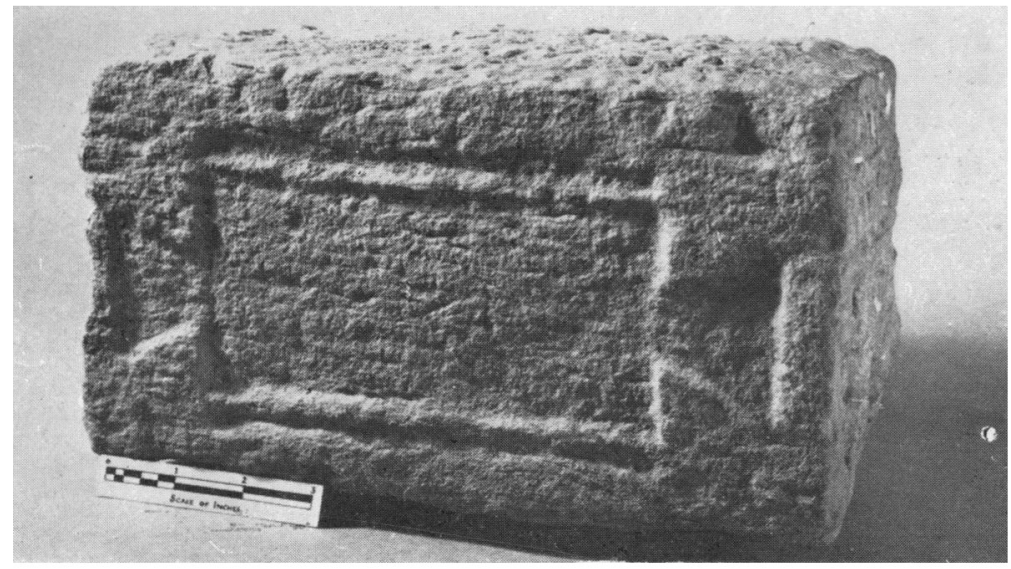

(Photo: RCAHM, Scotland; copyright reserzed)

B. Cramond. Building stone with blank ansate panel (p. 196).

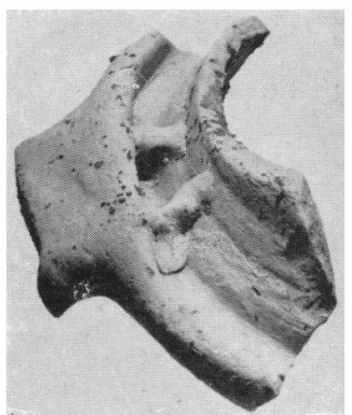

(Photo: RCAHM, Scotland; copyright reserved)

C. Cramond. Detail of fillets supporting spout of mortarium No. 25 (p. 2 I I). 


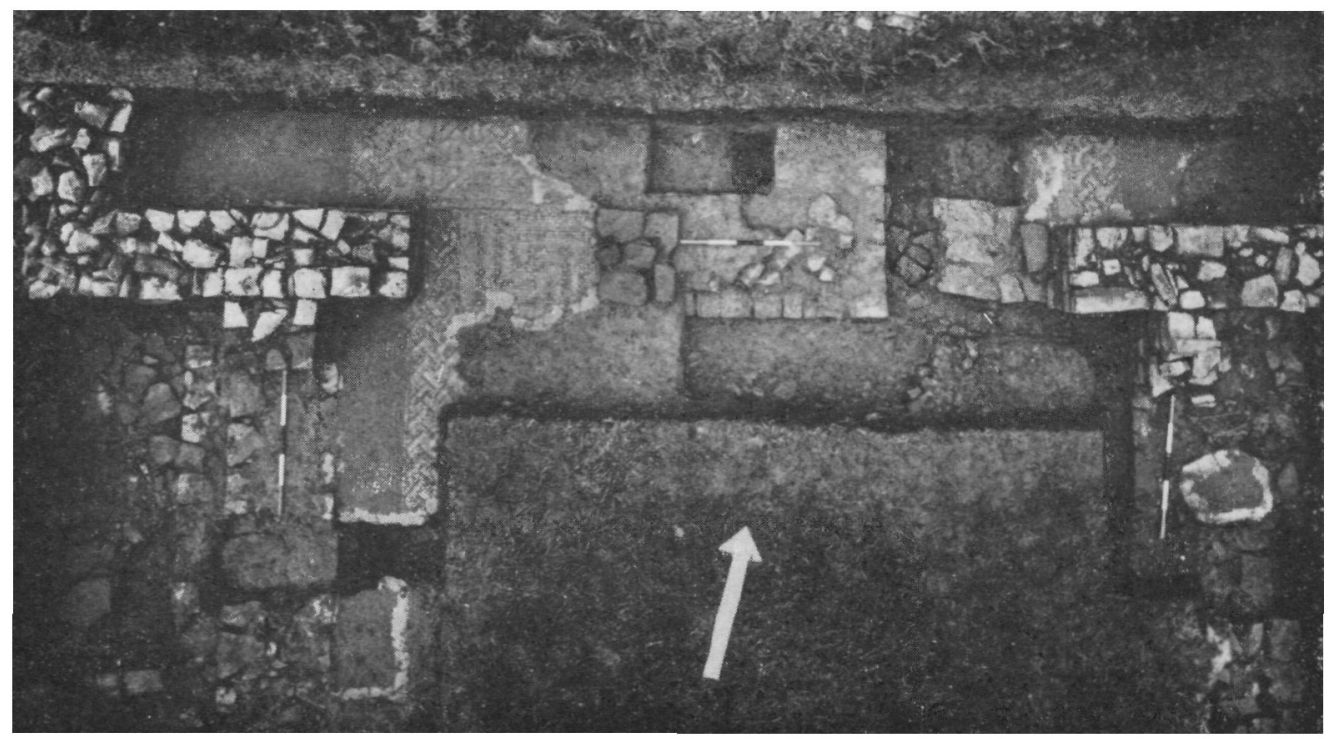

(Photo: RCAHM, Wales; copyright reserved)

A. Llantwit Major. Vertical view of excavations (p. 228). (Scale rod is I m long.)

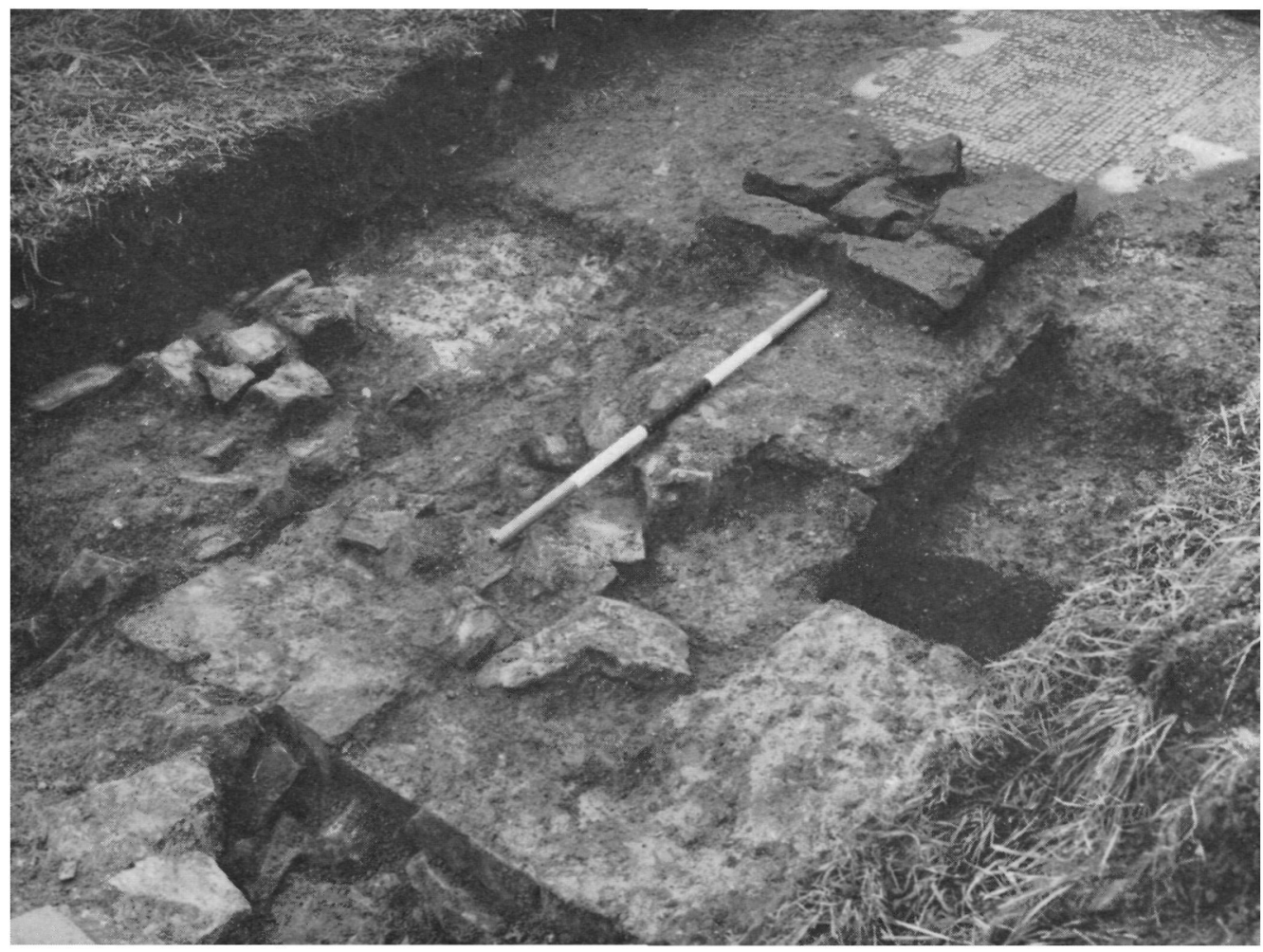

(Photo: RCAHM, Wales; copyright reserved)

B. Llantwit Major. Phase A wall from north-east (p. 229). (Scale rod is I m long.) 

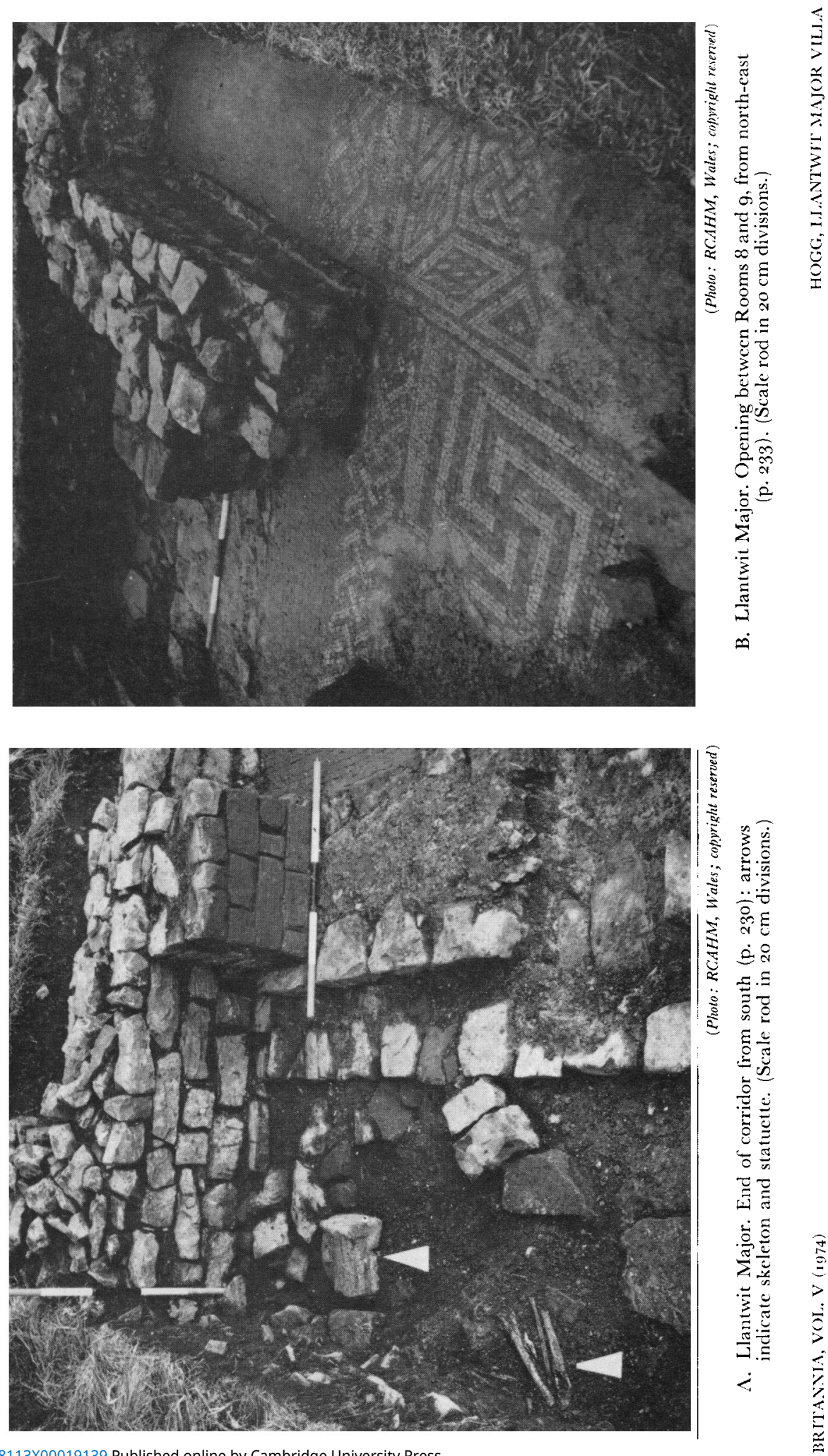


\section{PLATE XX}

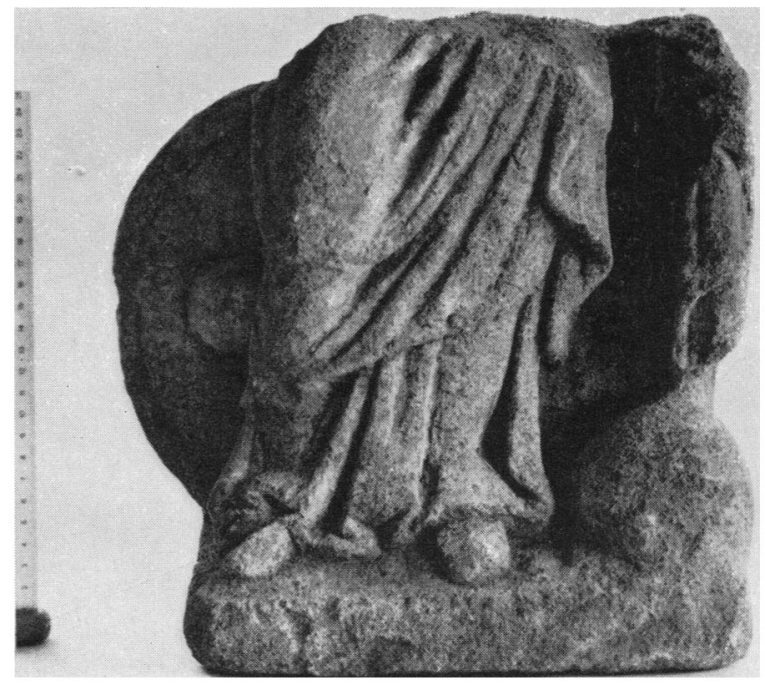

(Photo: RCAHM, Wales; copyright reserved)

A. Llantwit Major. Fortuna statuette. Height $30 \mathrm{~cm}$ (p. 242).
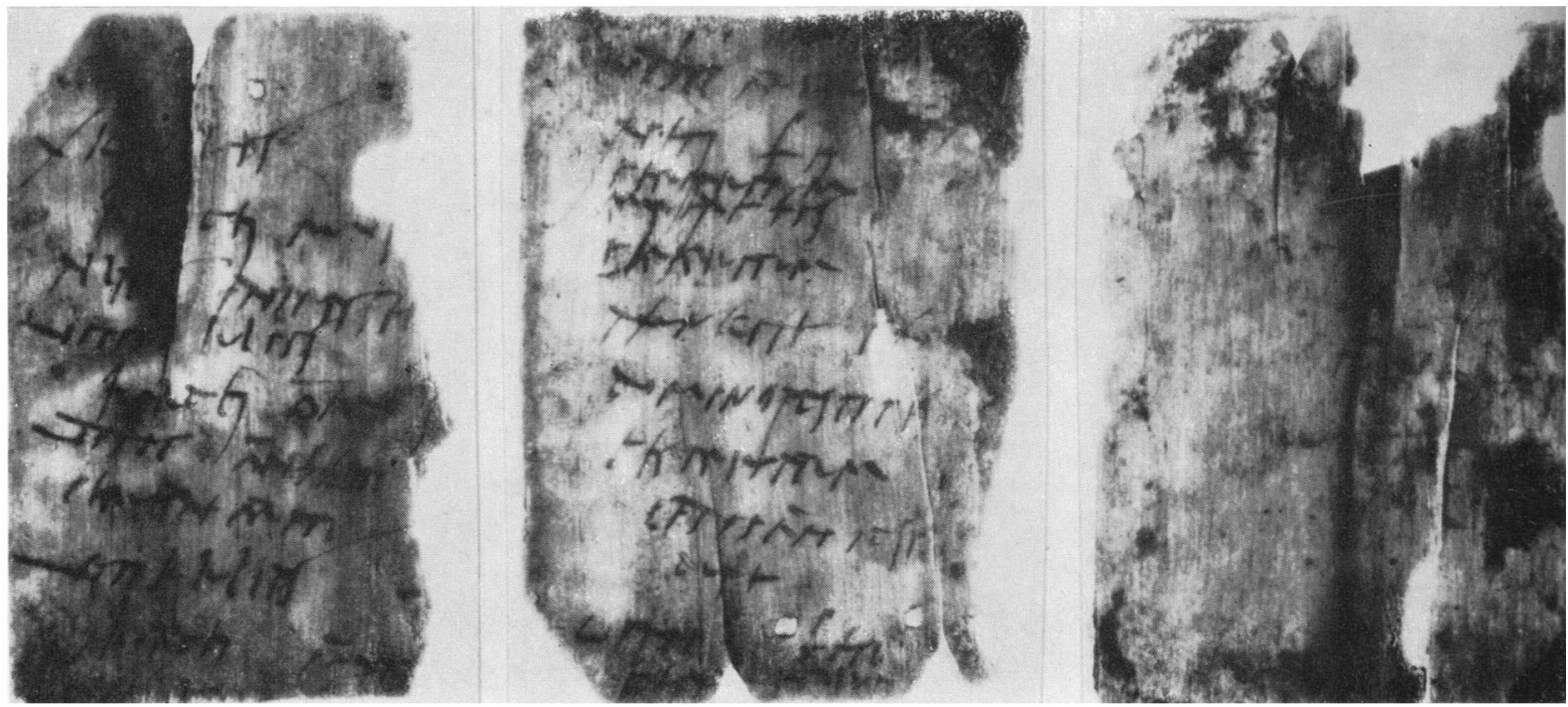

B. Fragment i, Fragment ii. Fragment iii.

(Photo: Alison Rutherford)

Vindolanda, Latin writing-tablet No. 33 (p. 360 ), published by permission of the Vindolanda Trust (责). 


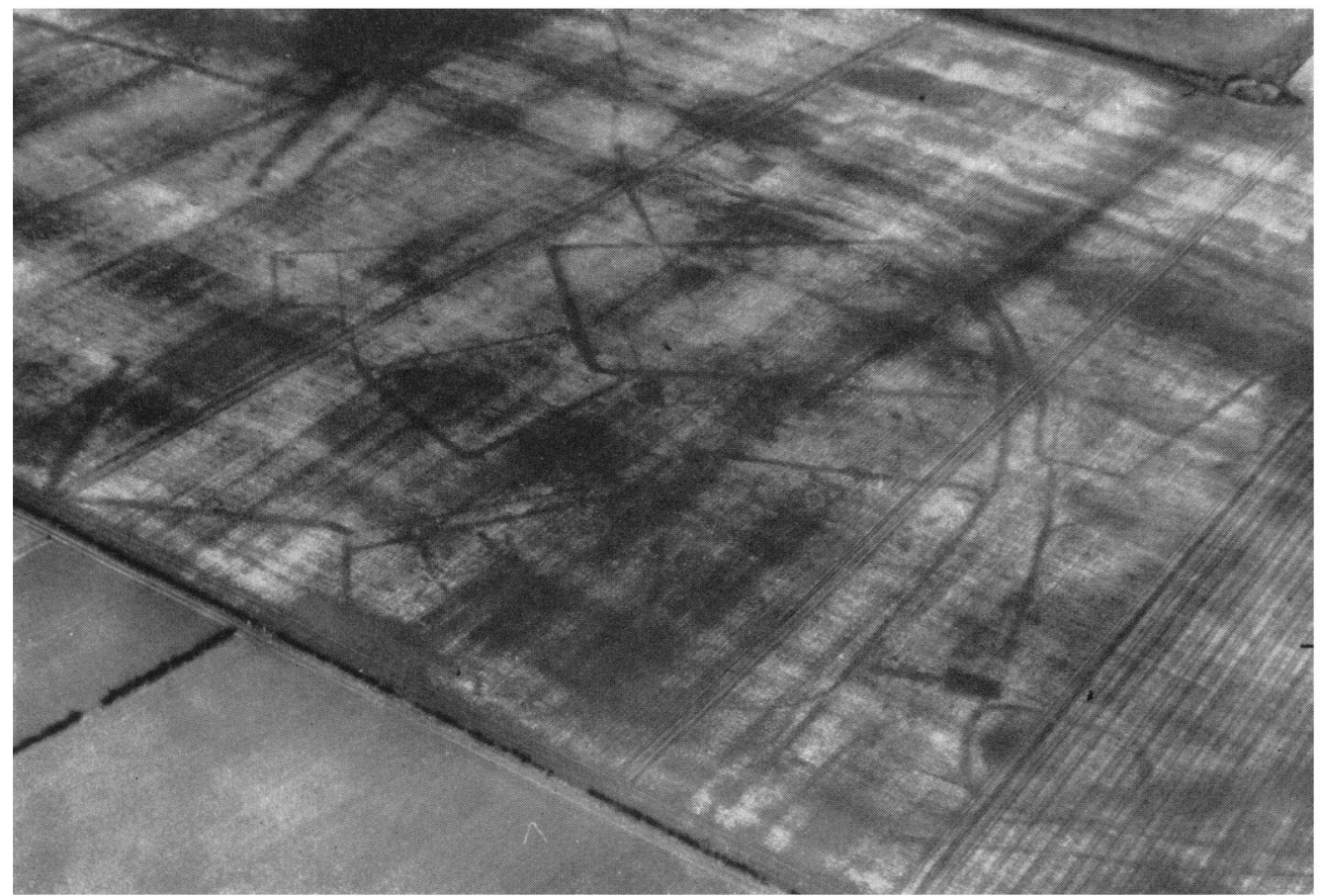

(Photo: Lniversity of Cambridge; Crown copyright reserved)

A. Soil-marks of an Iron-Age and Romano-British agricultural complex, Welton Wold (East Yorkshire), looking north (28 March 1956). The irregular enclosure below the centre of the photograph was found to contain a round house, a small rectangular house and two aisled barns, all of Roman date (p. 251 ).

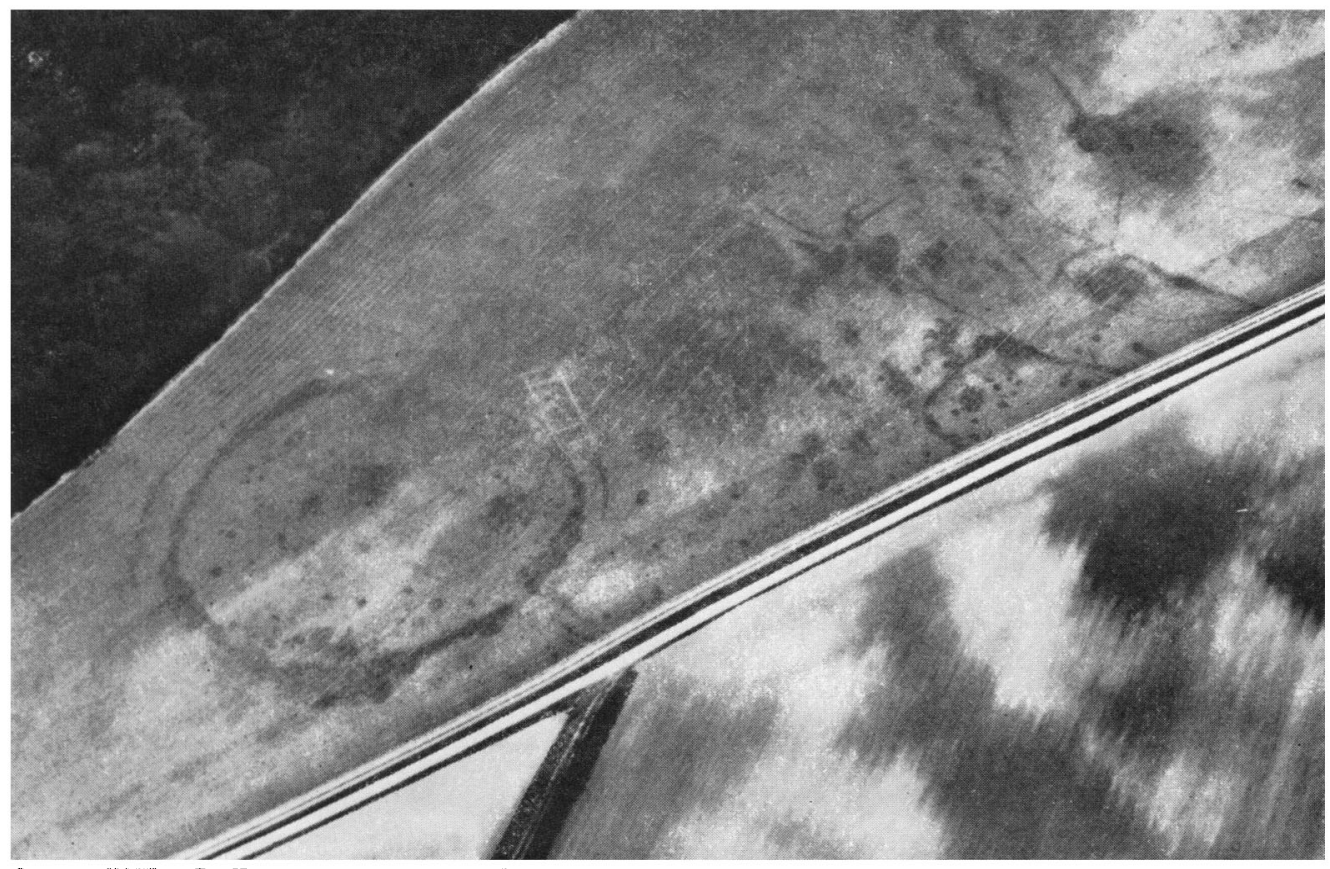

(Photo : University of Cambridge; copyright reserved)

B. Crop-marks of a Roman house on the site of a large Iron-Age settlement, Bazeley Copse, Micheldever

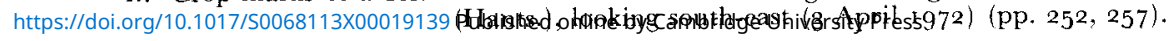




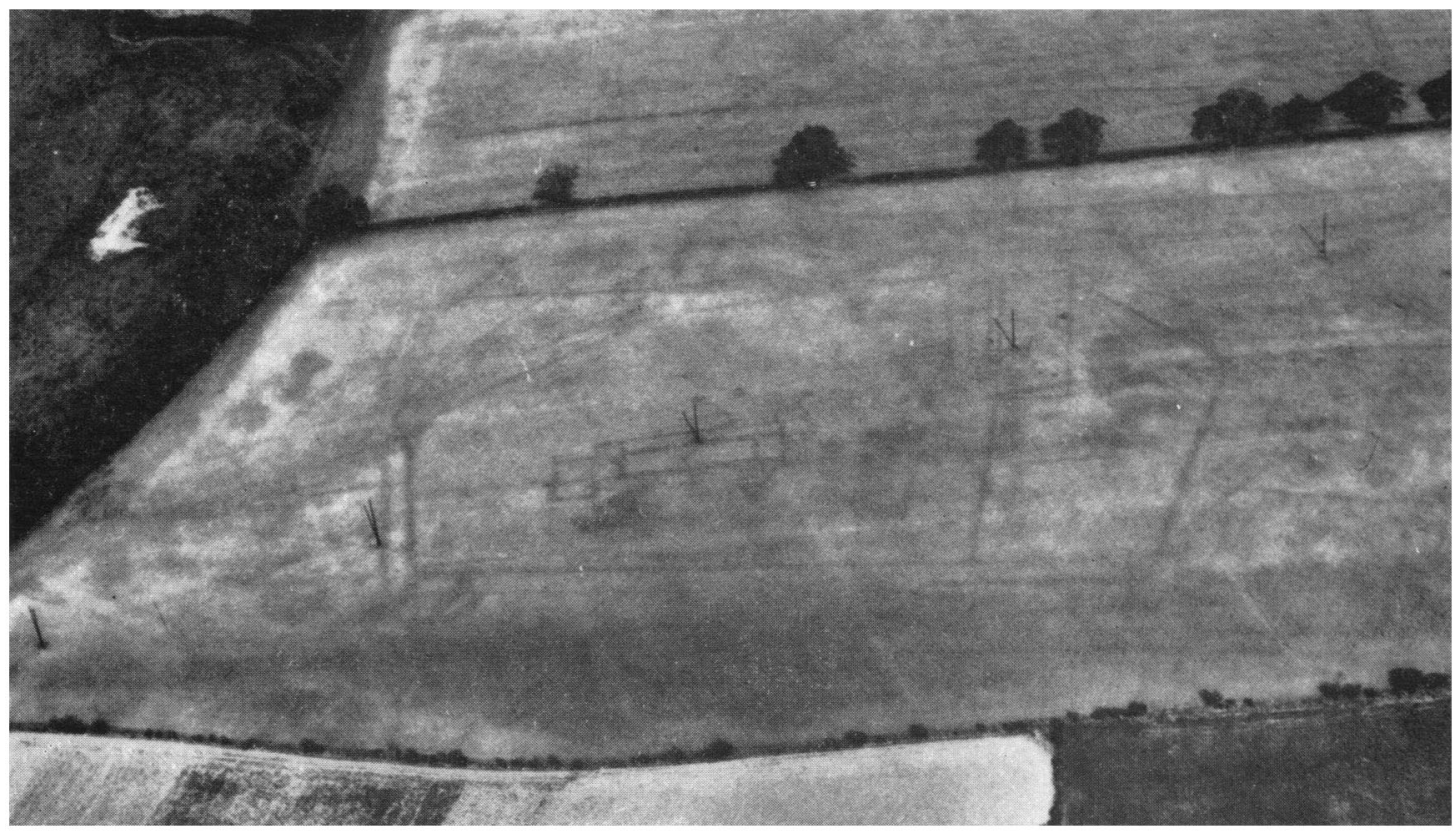

(Photo: Lnicersity of Cambiridge; copyright reserced

A. Crop-marks of a Roman villa, north-east of Lockington (Leics.). looking cast (22 June 1959). An Iron-Age settlement lies immediately to the west. in the two fields at the bottom of the photograph. ( The row of $\checkmark$-shaped features crossing the villa belong to a modern power-line) (pp. 253.257).

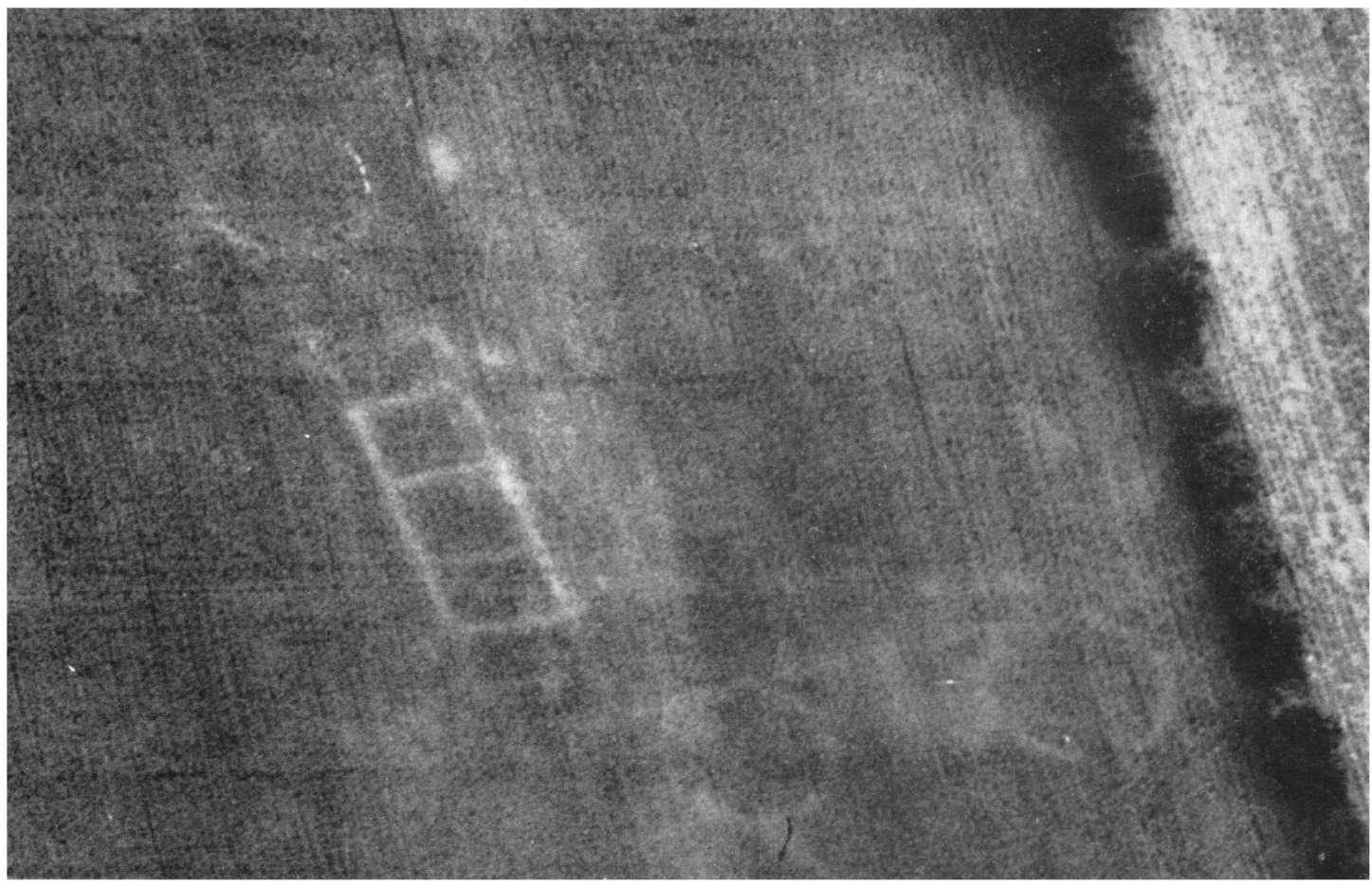

(Photo: Lniversity of Cambridge; copyright resercel)

B. Crop-marks of rectangular and circular houses, south-east of Great Doddington (Northants.), looking south-south-east (29 June 1970) (p. 255 f.). 


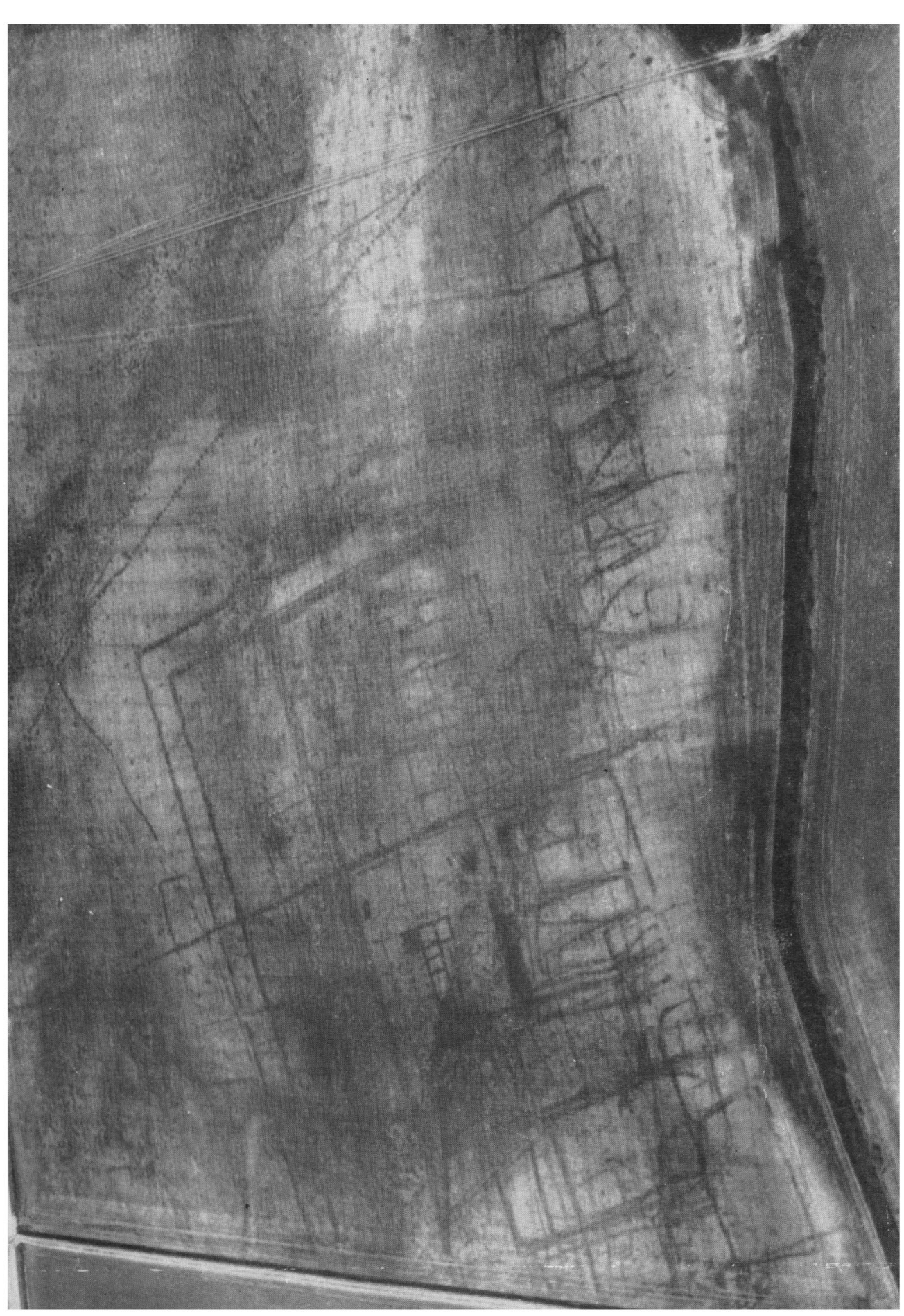




\section{PLATE XXIV}

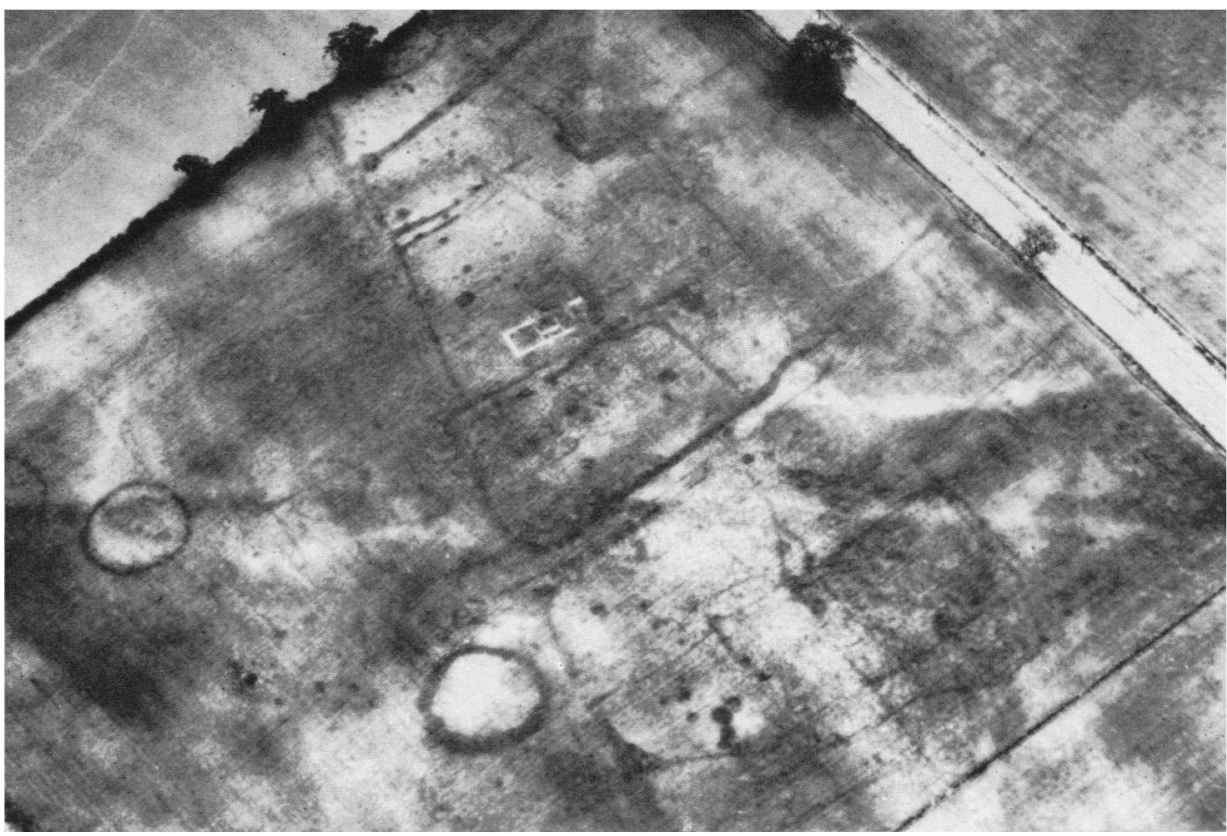

(Photo: University of Cambridge; Crown copyright reserved)

A. Crop marks of a Roman house within a system of small fields, north-west of Barnack (Huntingdon and Peterborough), looking south-east (9 July I962) (p. 257).

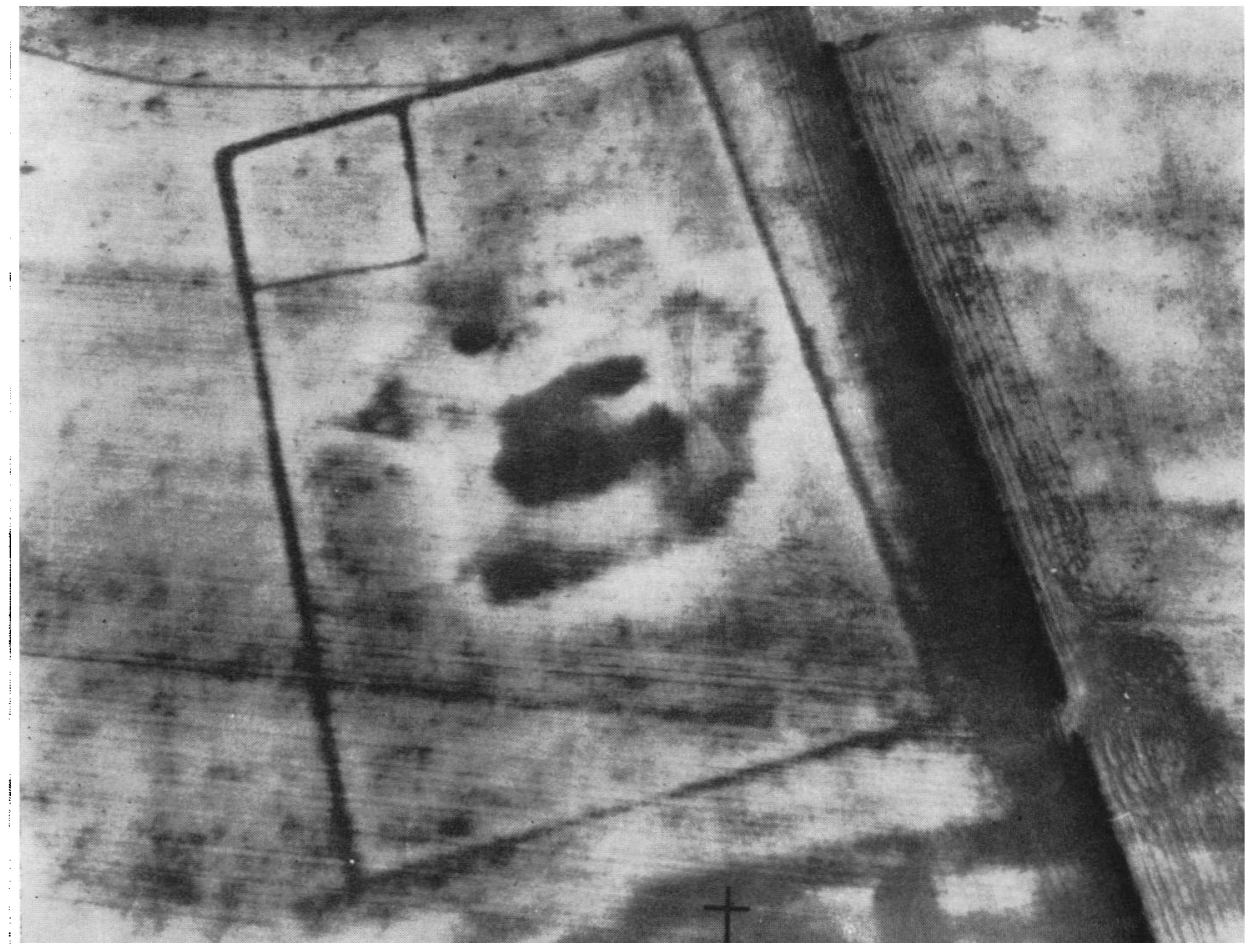

(Photo: University of Cambridge; copyright reserved)

B. Soil-marks of a villa-enclosure, Allington Hill, Bottisham (Cambs.), looking south-east (6 April I 964) (p. 256). 


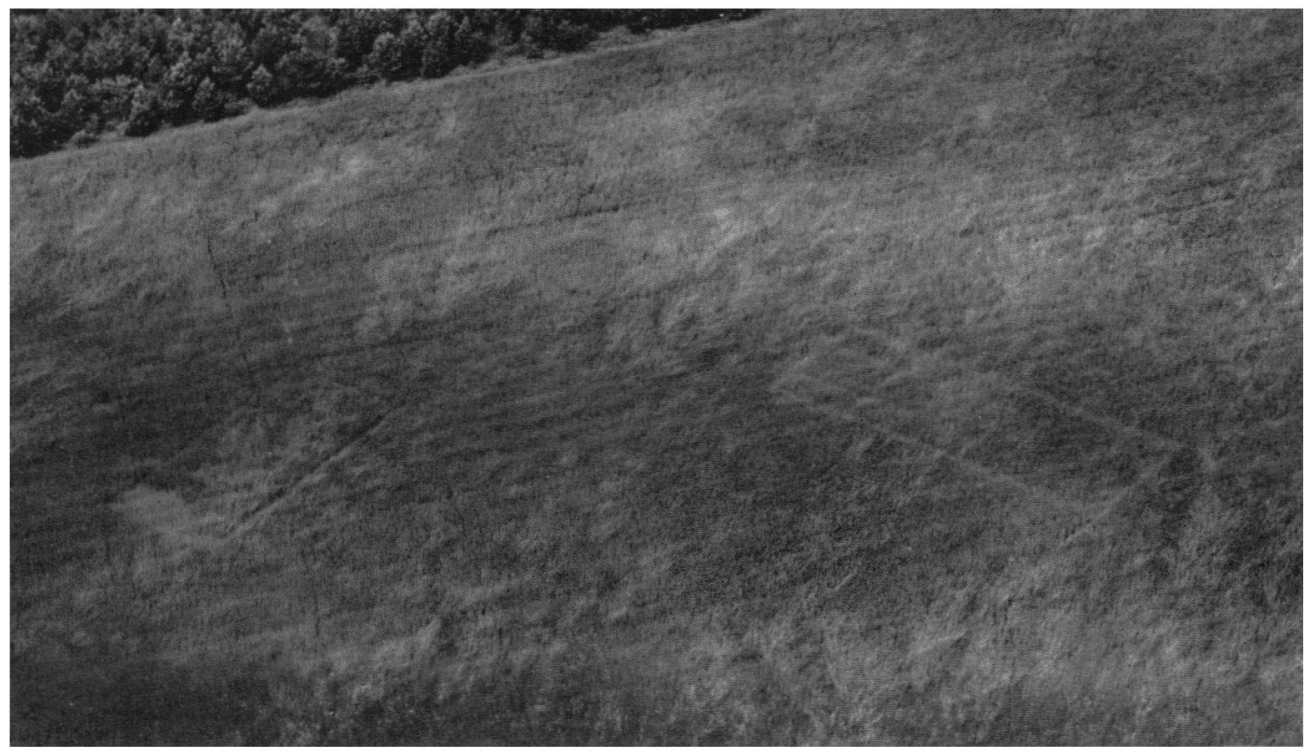

(Photo: University of Cambridge; copyright reserved)

A. Crop-marks of Roman buildings inside the Iron-Age hillfort of Tidbury Ring (Hants.), looking north (18 June 1948) (pp. 252, 259).

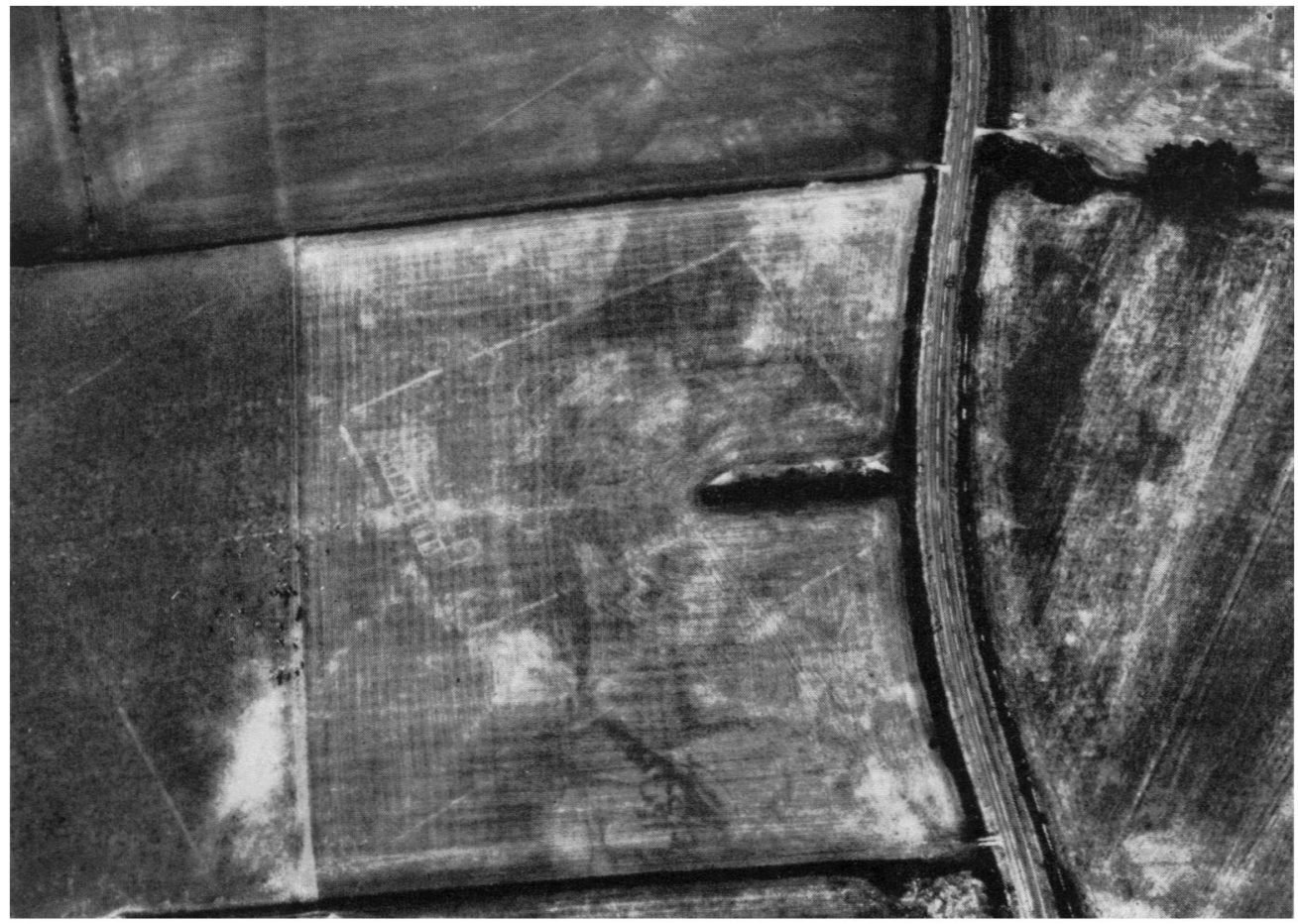

(Photo: University of Cambridge; copyright reserved)

B. Crop-marks of a Roman villa, Islip (Oxon.), looking south-east (23 June 1970). The buildings lie within two walled enclosures (p. 257). 

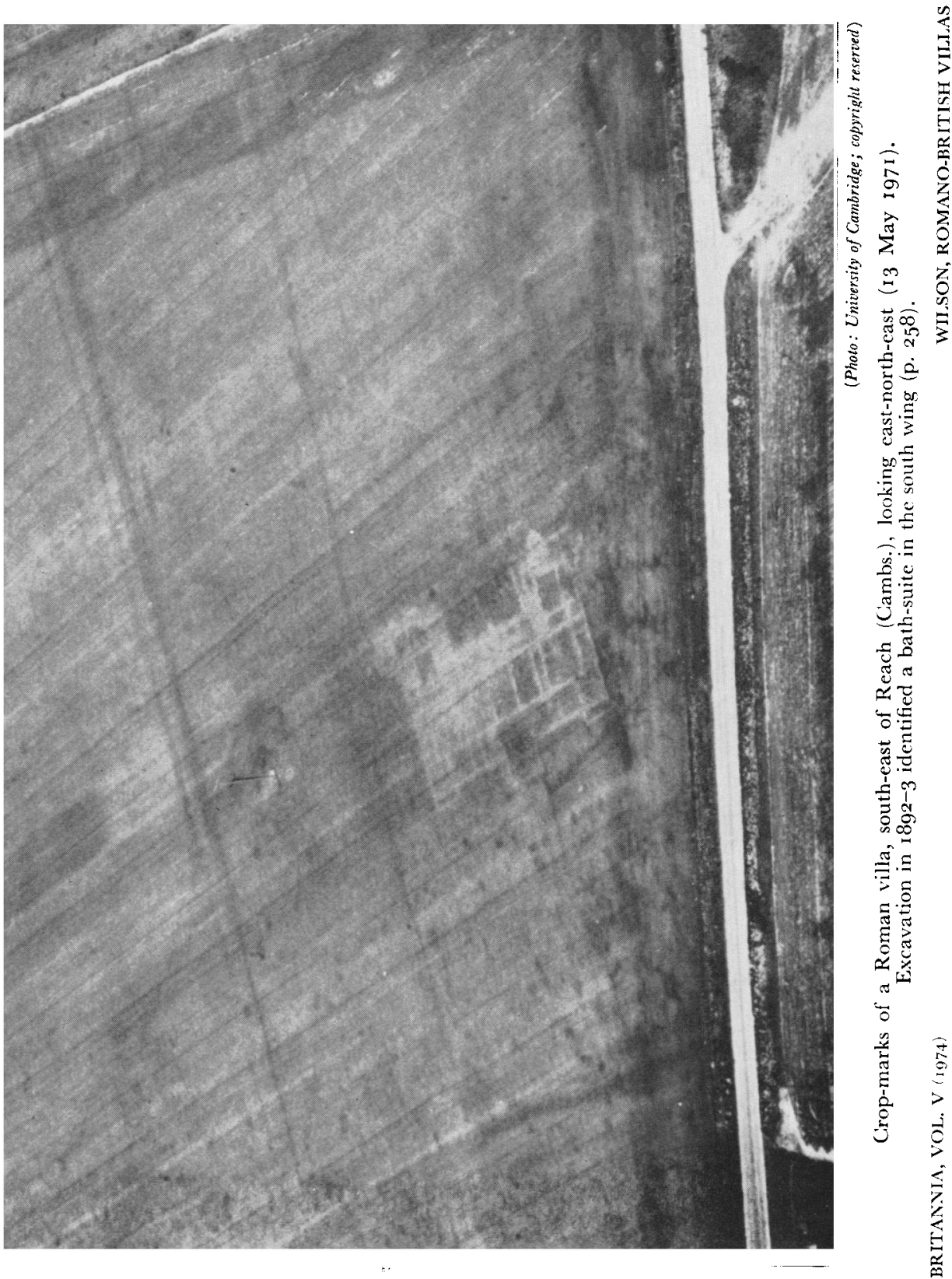


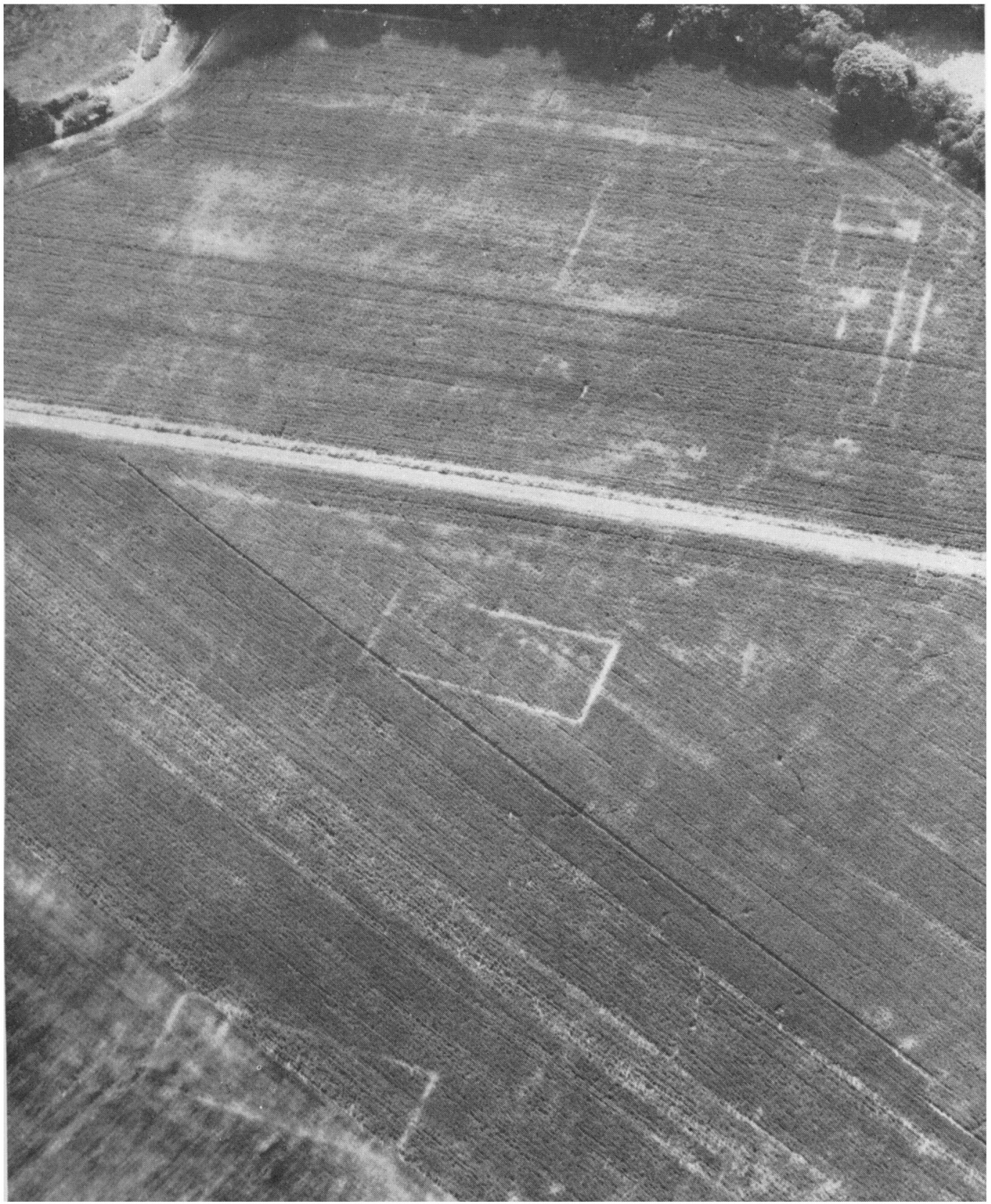

(Photo: Lniversily of Cambridge; Crown copyright reserved)

Crop-marks of a Roman villa, Radwell (Herts.), looking west-south-west (9 July 1962). The principal house is thought to lie beside the river at the top of the photograph (p. 260). 


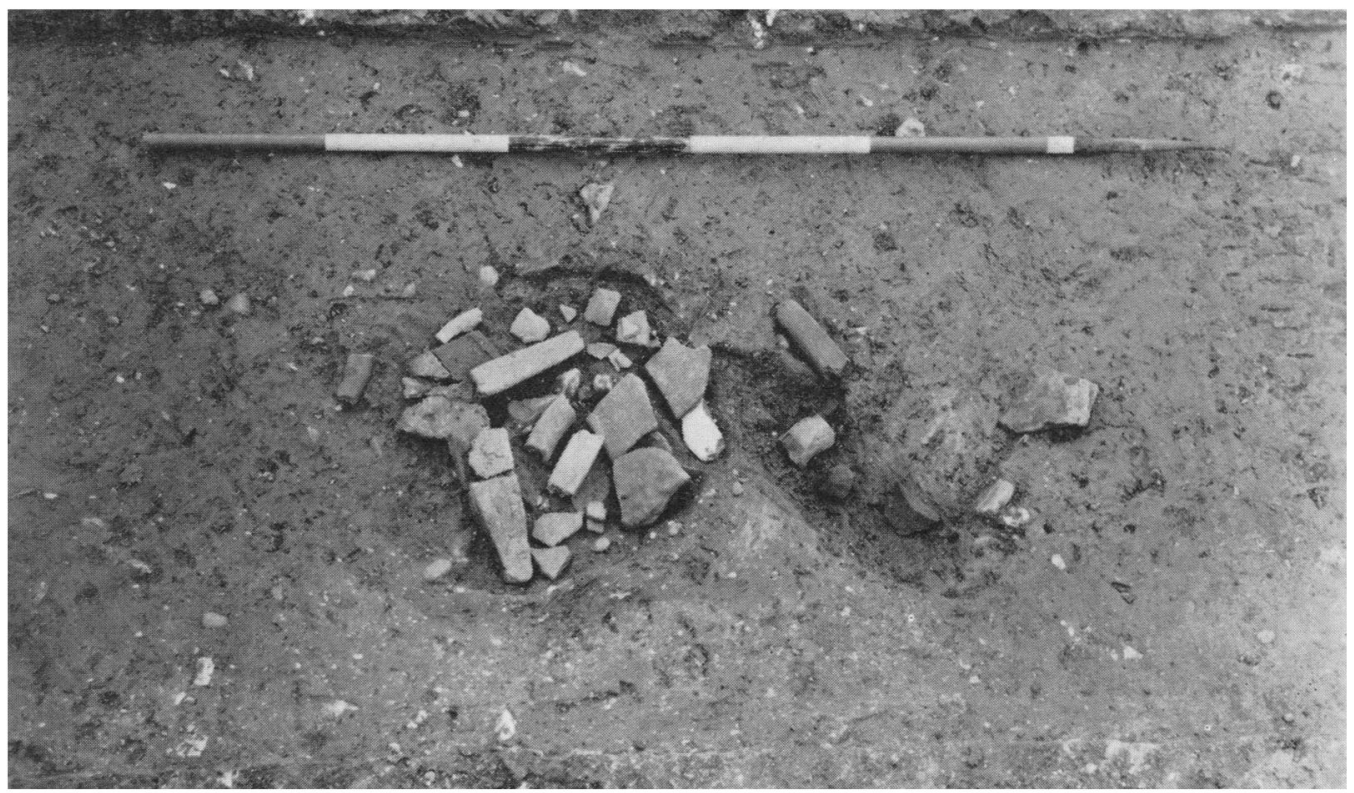

(Photo: A. J. George)

A. Rushden, Kiln III (Type IA) (p. 265).

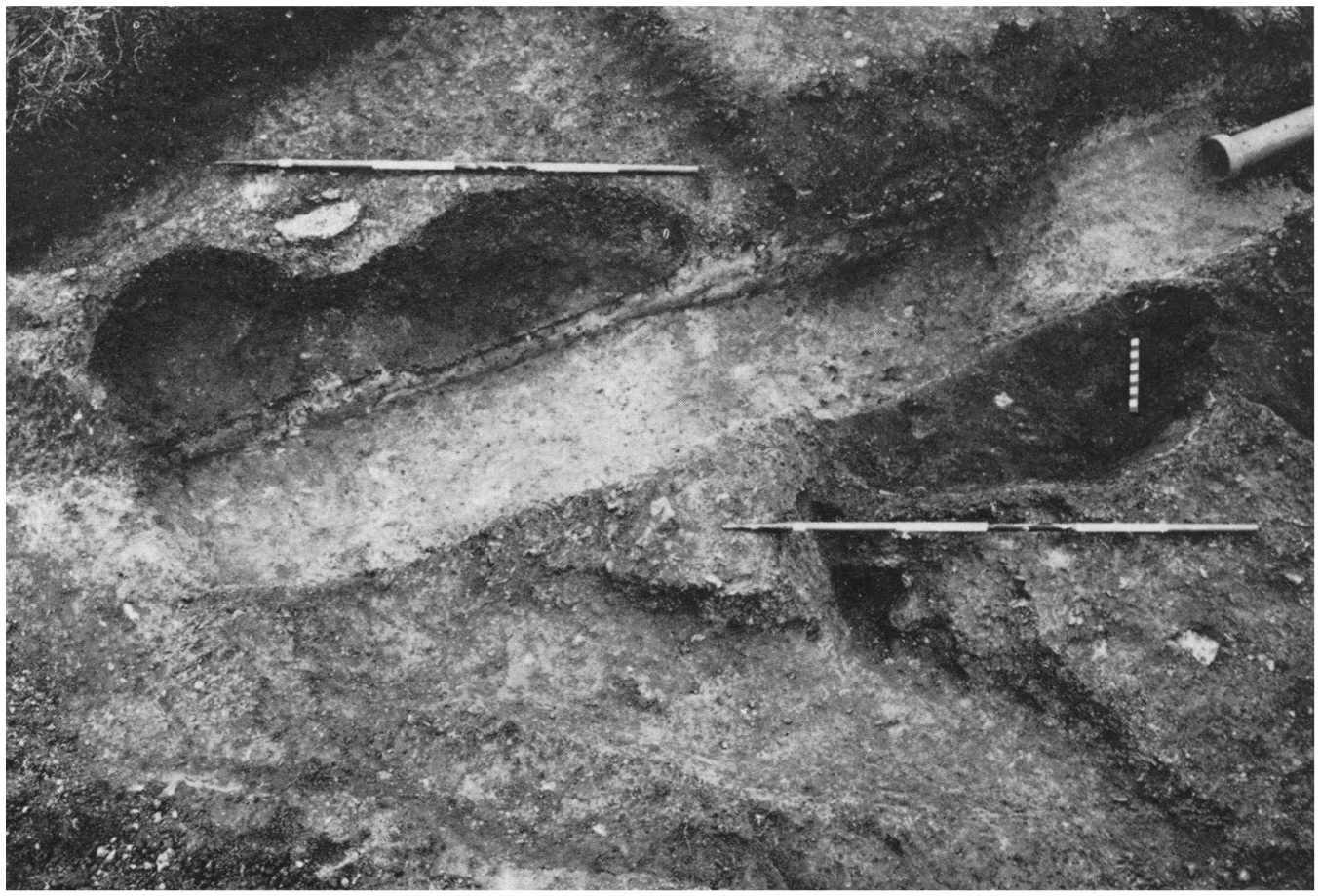

(Photo: H. C. R. Frost)

B. Hardingstone (Site II), Kilns I and II (Type IC) (p. 270). 


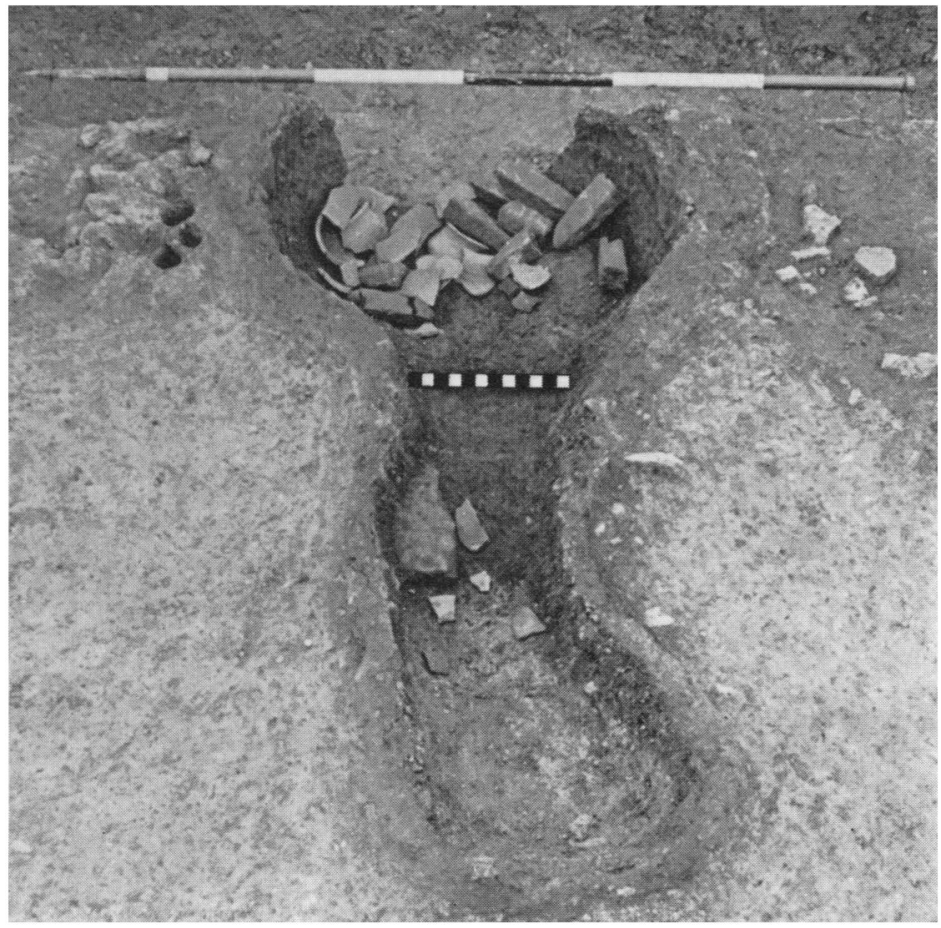

(Photo: S. T. Bayes)

A. Hardingstone (Site II), Kiln IV (Type IIIA) (p. 273).

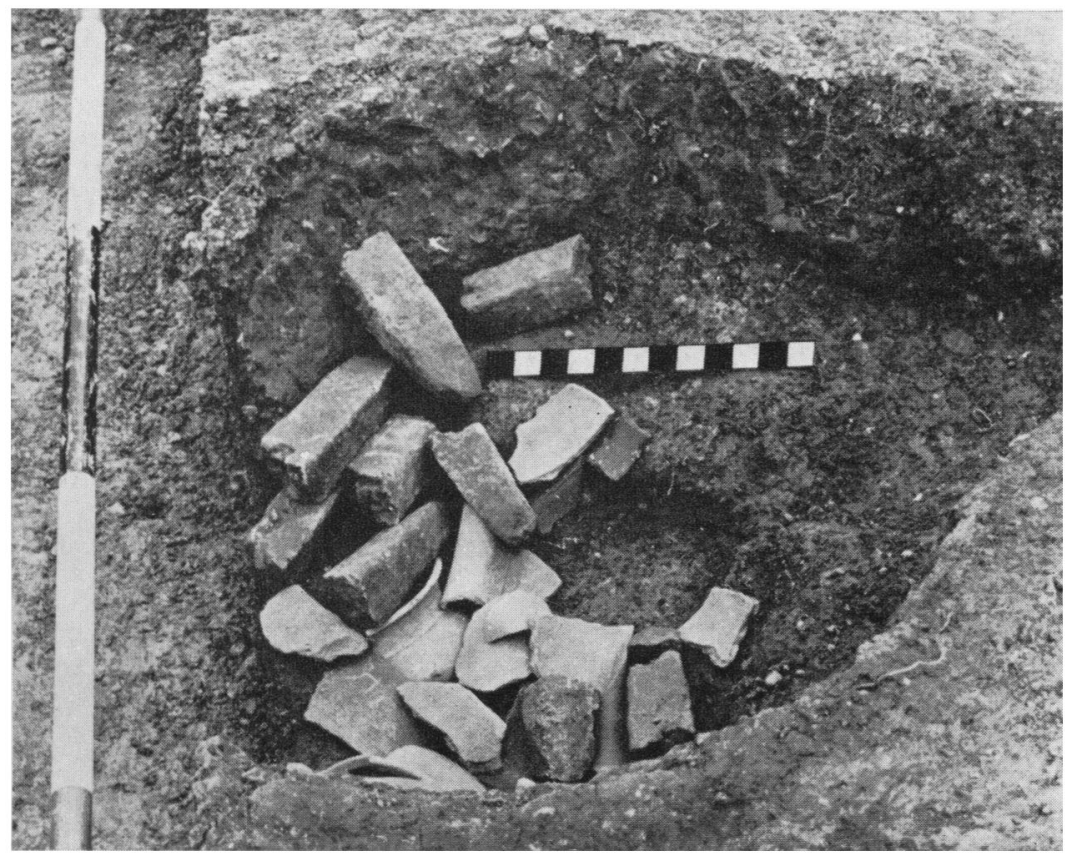

(Photo: S. T. Bayes)

B. Hardingstone (Site II), Kiln IV. Furnace bowl with debris (p. 273). 


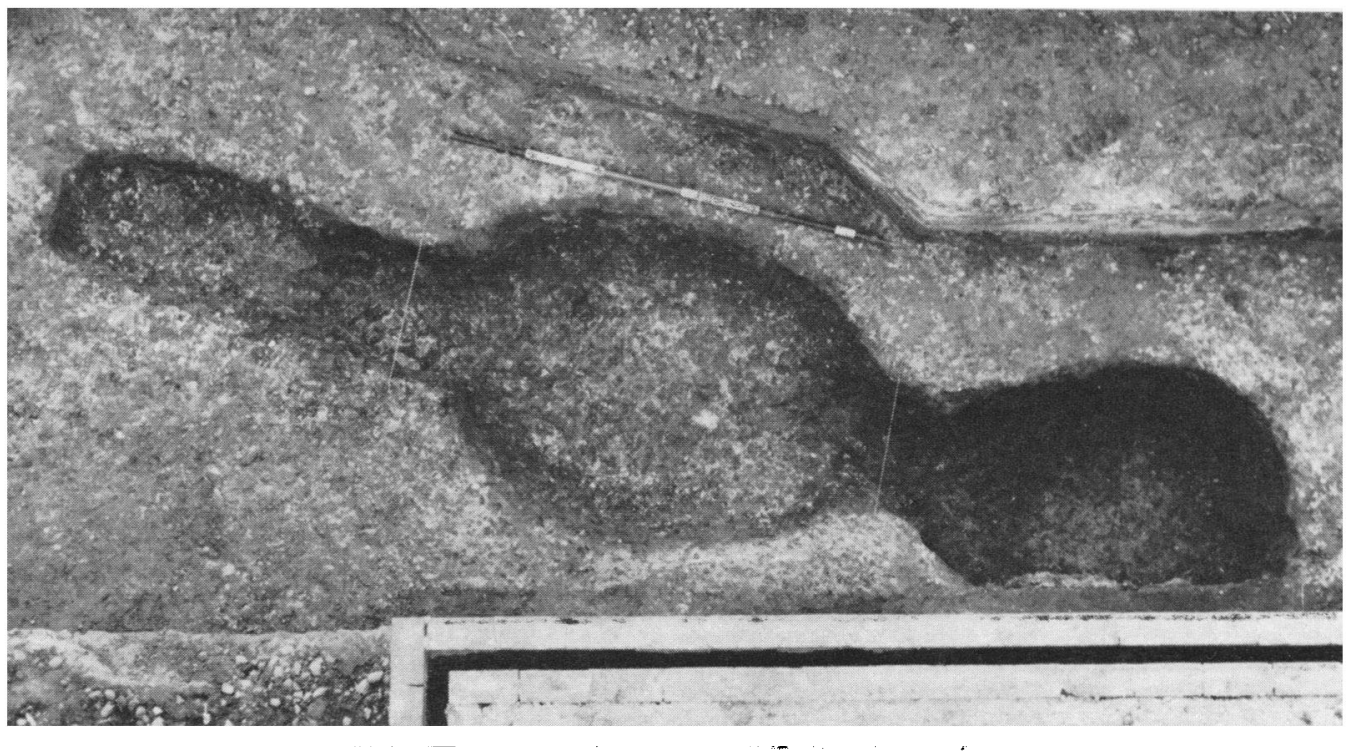

(Pholo: H. C. R. Frost)

A. Hardingstone (Site I), Kiln VII (Type IIB) (p. 272).

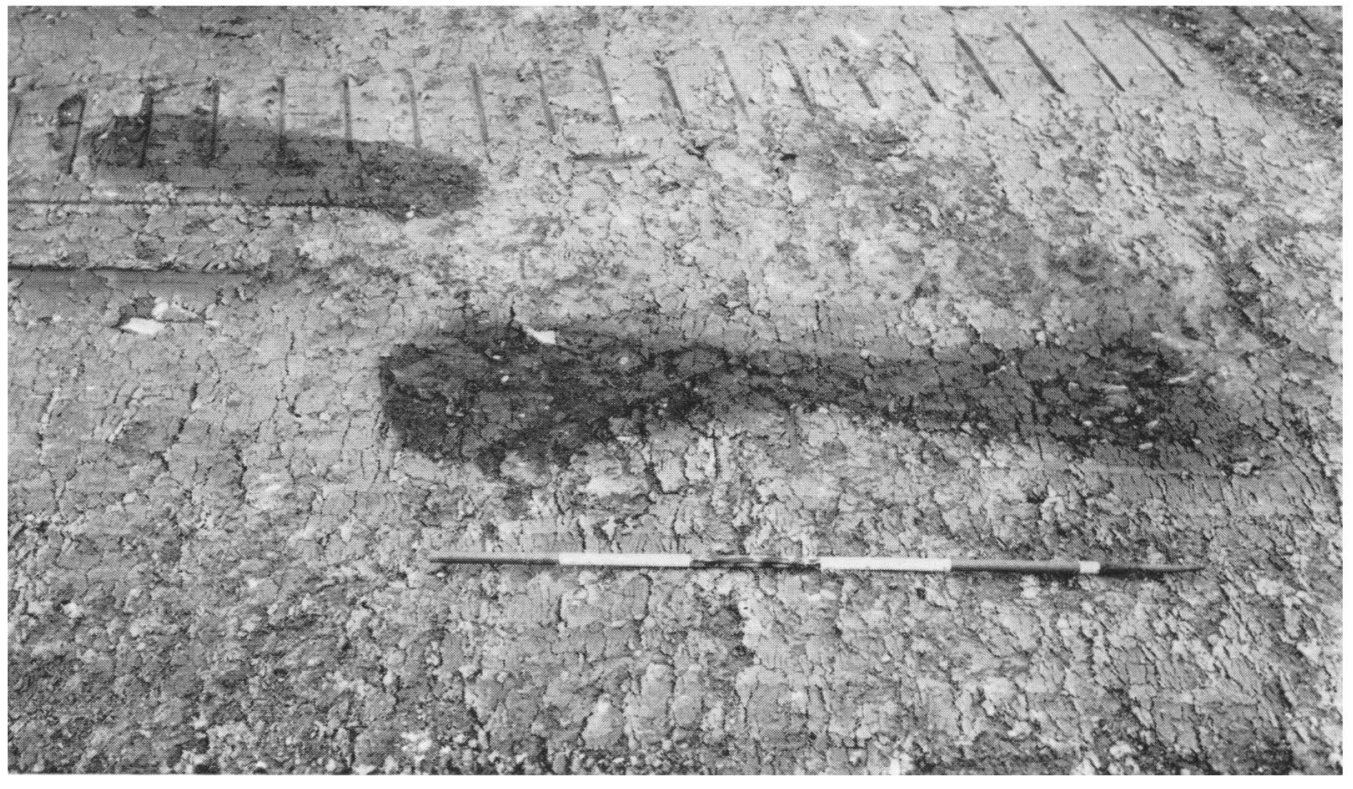

(Photo: A. 7. George)

B. Rushden, Kiln V (Type IIIB) (p. 273). 


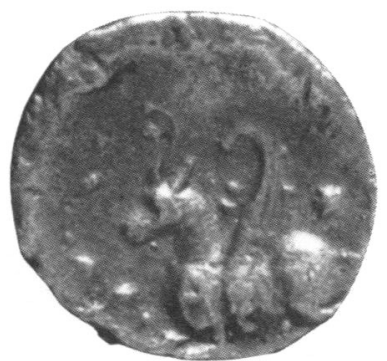

(Photo: R. L. Wilkins, by permission, Ashmolean Museum)

A. Reverse of silver coin of Tasciovanus $\left(\frac{3}{1}\right)$ (p. 374).

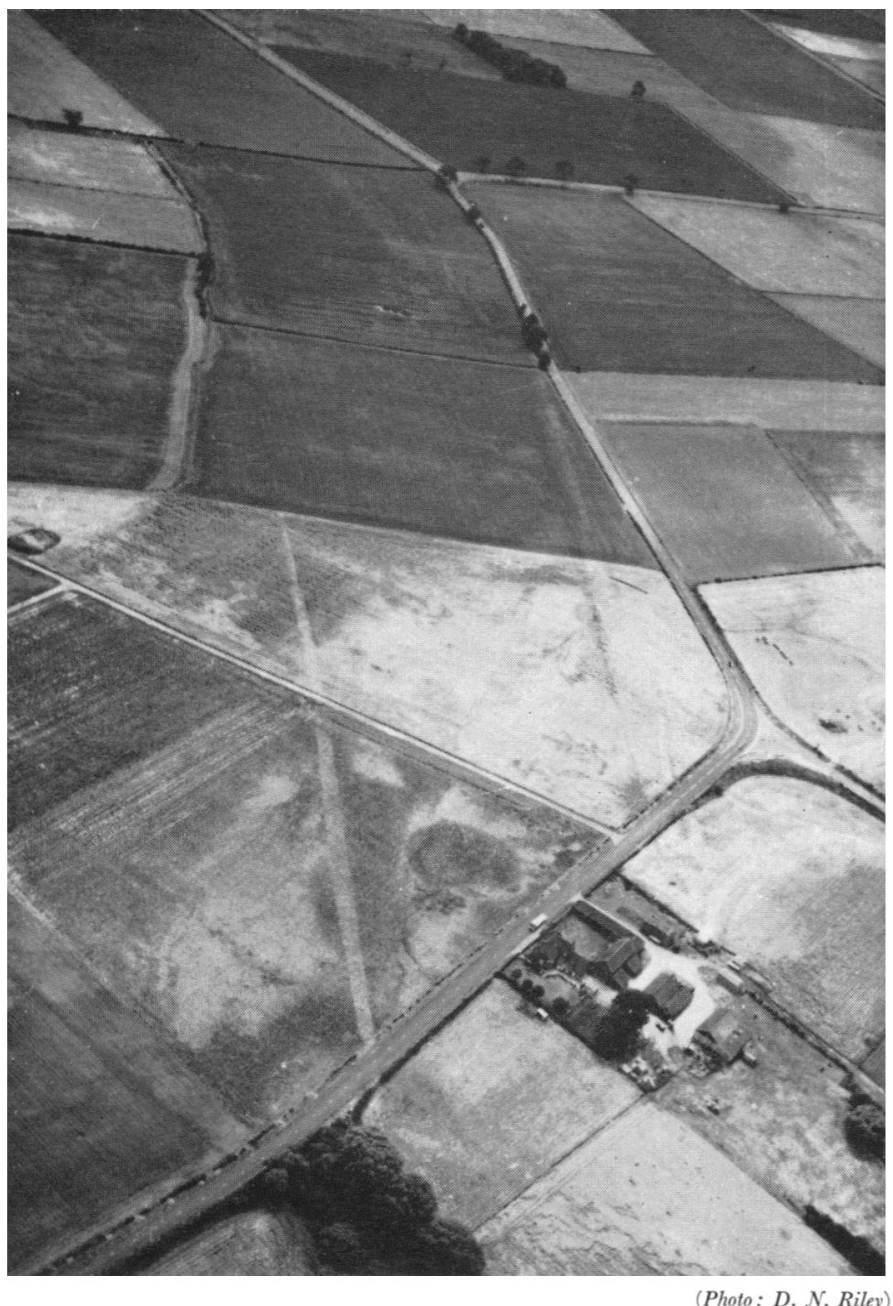

B. The northern end of Ermine Strect looking south-south-west (19 July I97 I) (p. 375): Eastfield Farm is at bottom right. The linear crop-mark on left, parallel to Ermine Street, is a modern pipe-trench. 


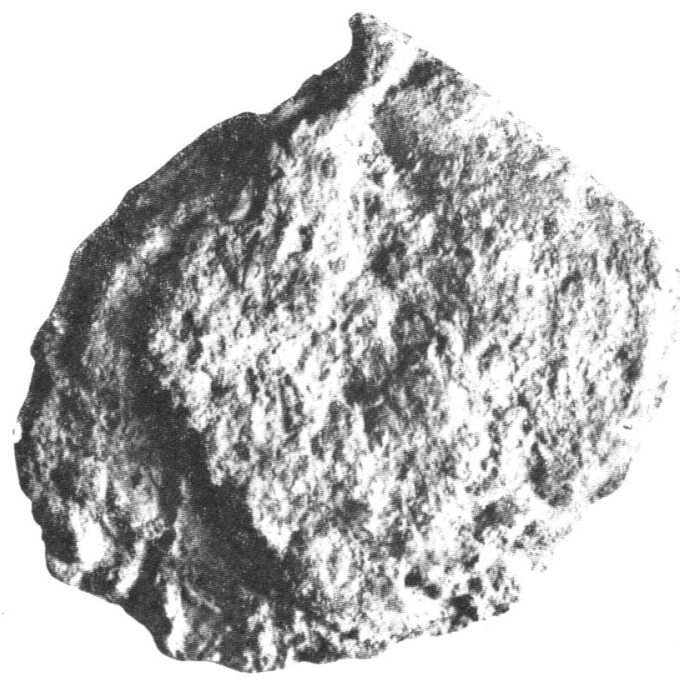

(Photo: R. L. Wilkins)

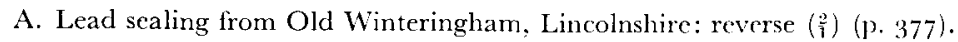

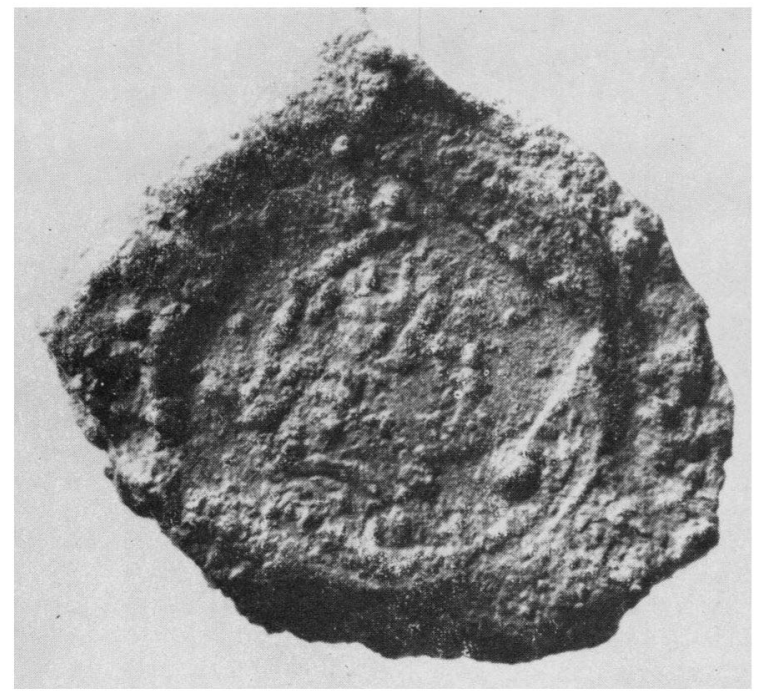

(Photo: R. L. Wilkins)

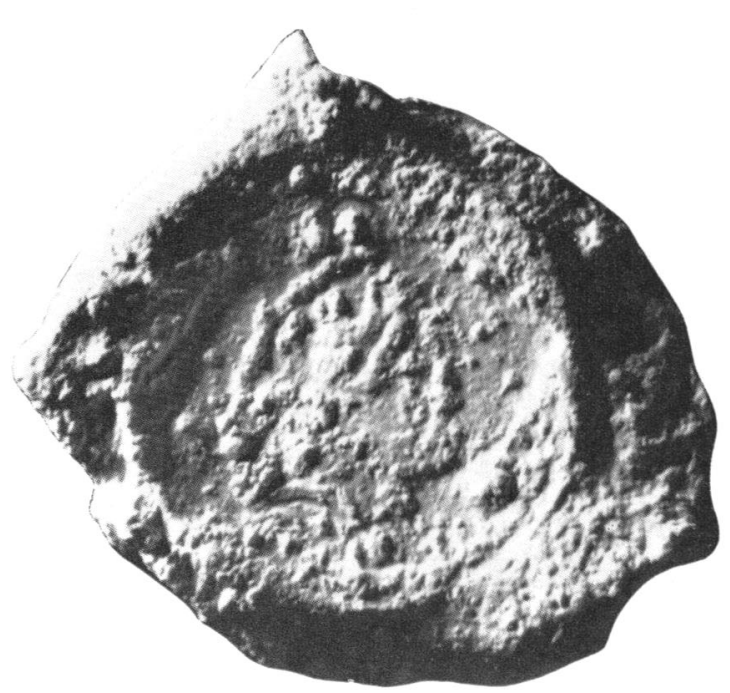

(Fhoto: R. L. Wilkins)

B. Old Winteringham lead sealing: obverse $\left(\frac{2}{1}\right)$.

C. The same: cast of obverse $\left(\frac{O}{\mathbf{i}}\right)$. 

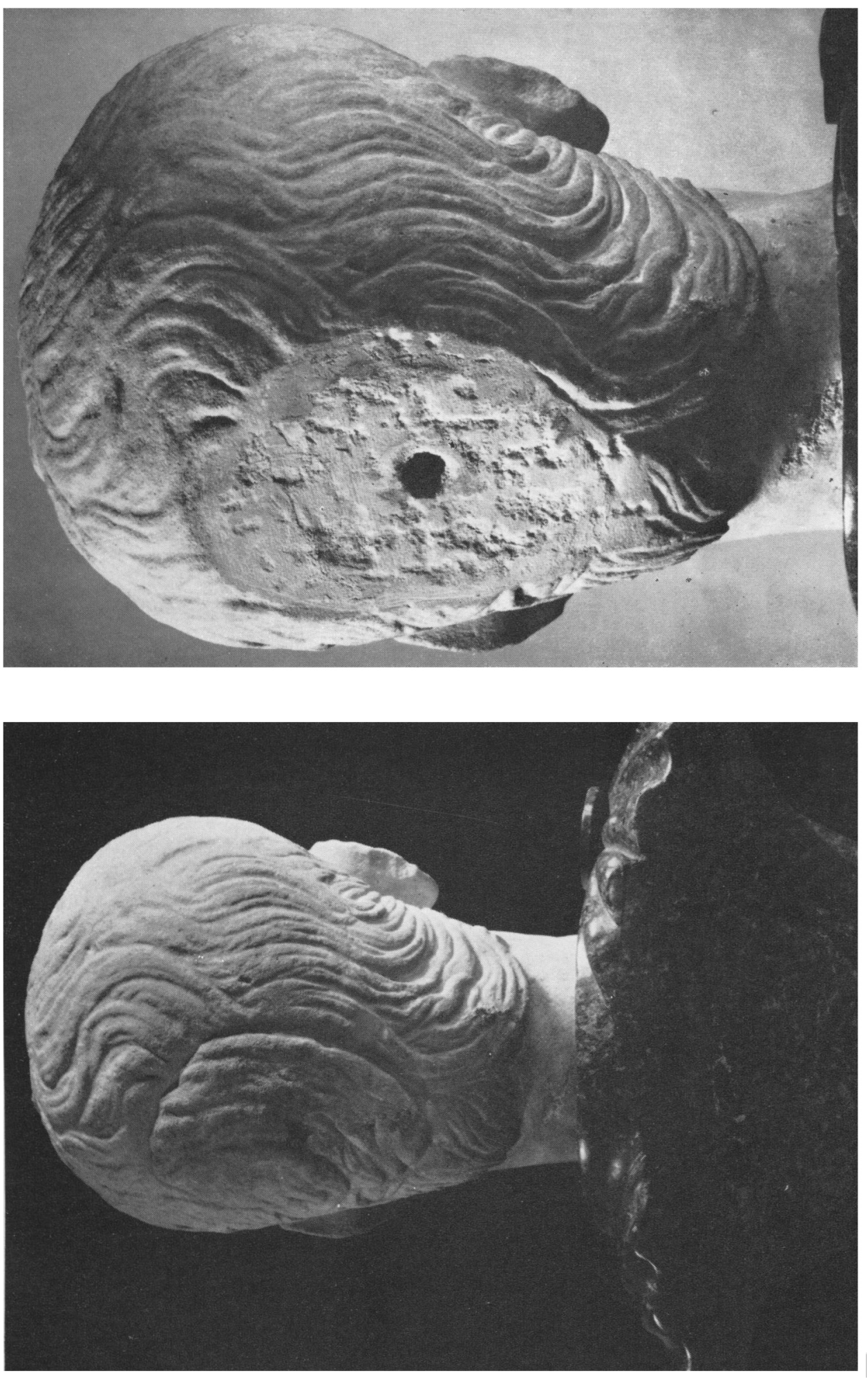
PLATE XXXIV
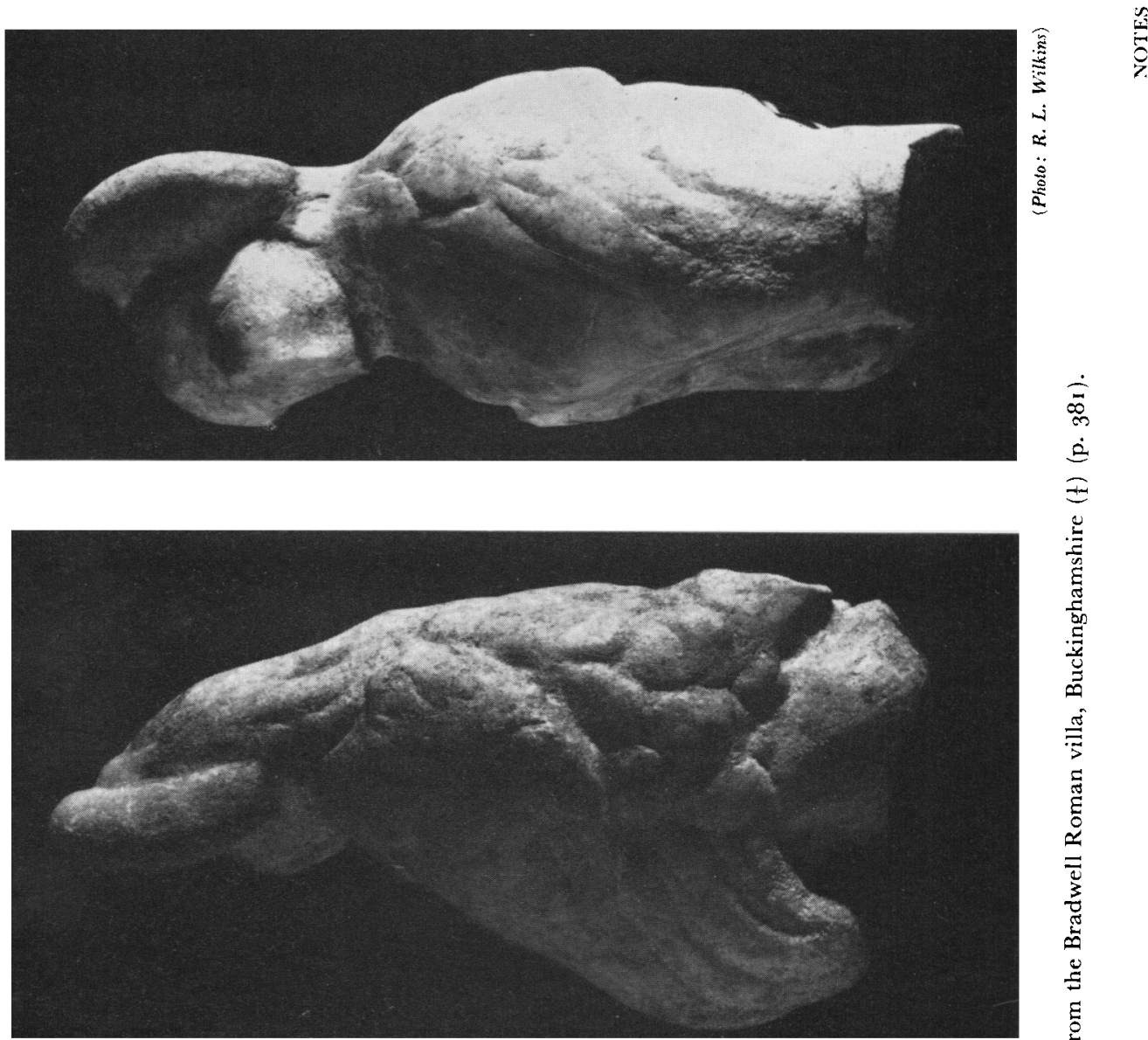

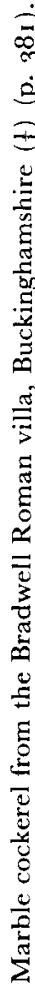

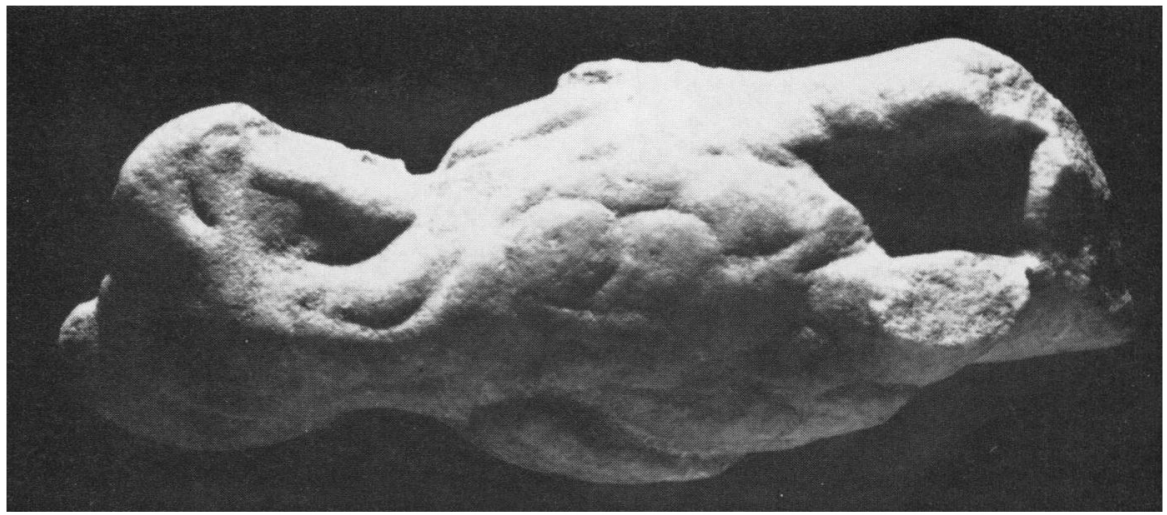

5 


\section{PLATE XXXV}

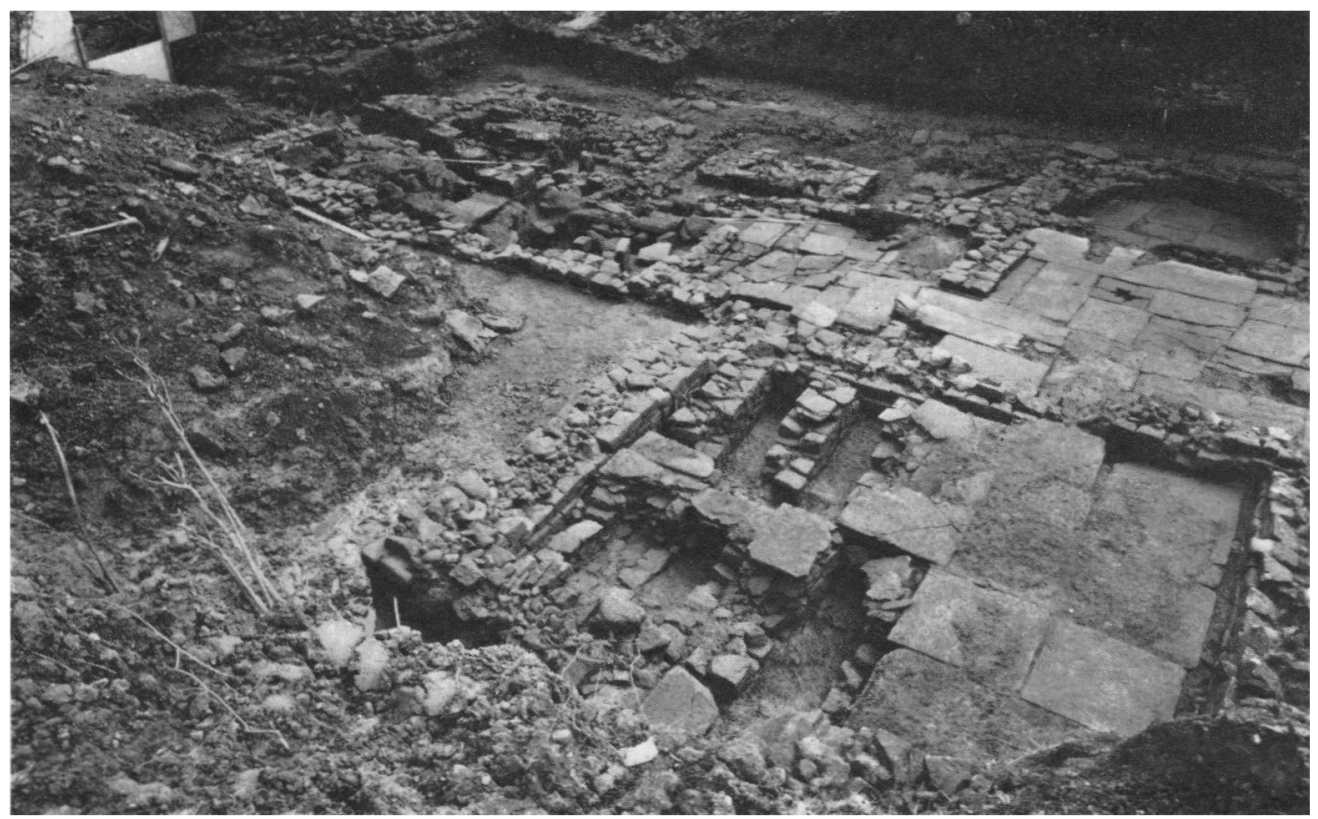

(Crown copyright reserved)

A. Bearsden, New Kilpatrick. The bath-house looking south. The hot dry room is in the foreground, the hot steam range across the centre with the entrance hall to the right, and the cold bath top right (p. 405$)$.

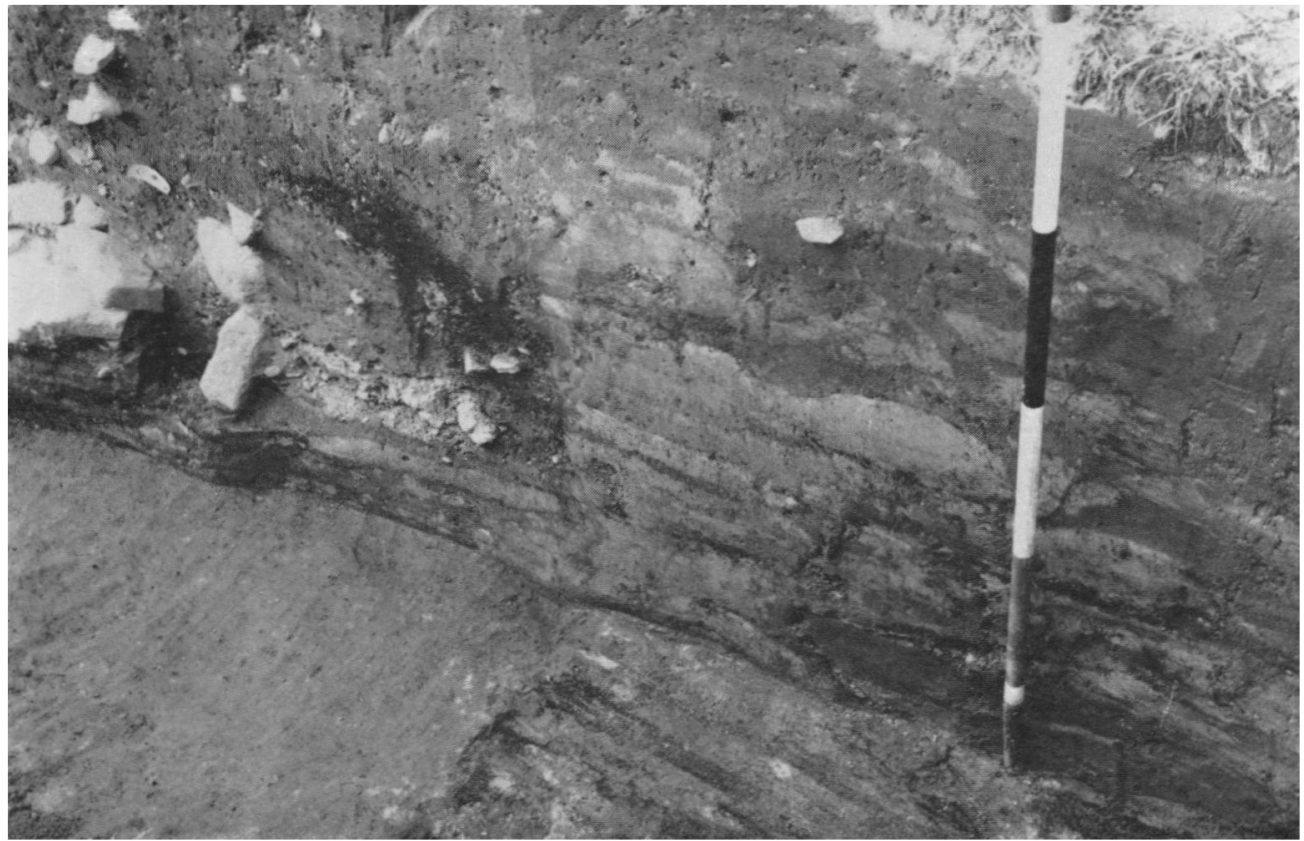

Photo: R. Goodburn

B. Strageath fort. Vertical back of Flavian turf rampart in the centre; to left of it is (i) base of Flavian turf ascensus: (ii) Antonine I intervallum road; (iii) ash from Antonine II ovens: the stones of the back of the oven are on the left, cutting the gravel (p. 402 ). 


\section{PLATE XXXVI}

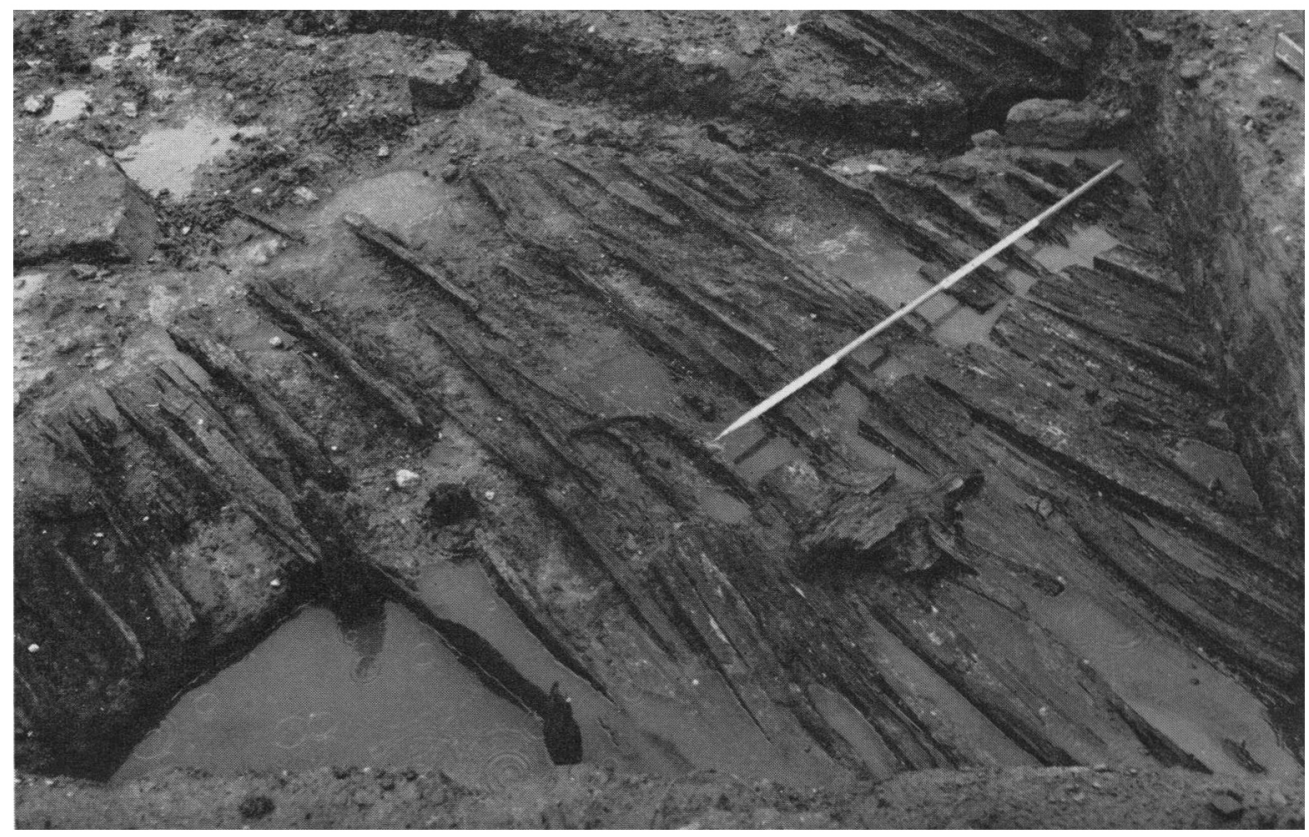

(Photo: D. Charlesworth)

A. Carlisle. Upper layer of timber raft with overlying turf structure (right): medieval well in foreground (p. 4II).

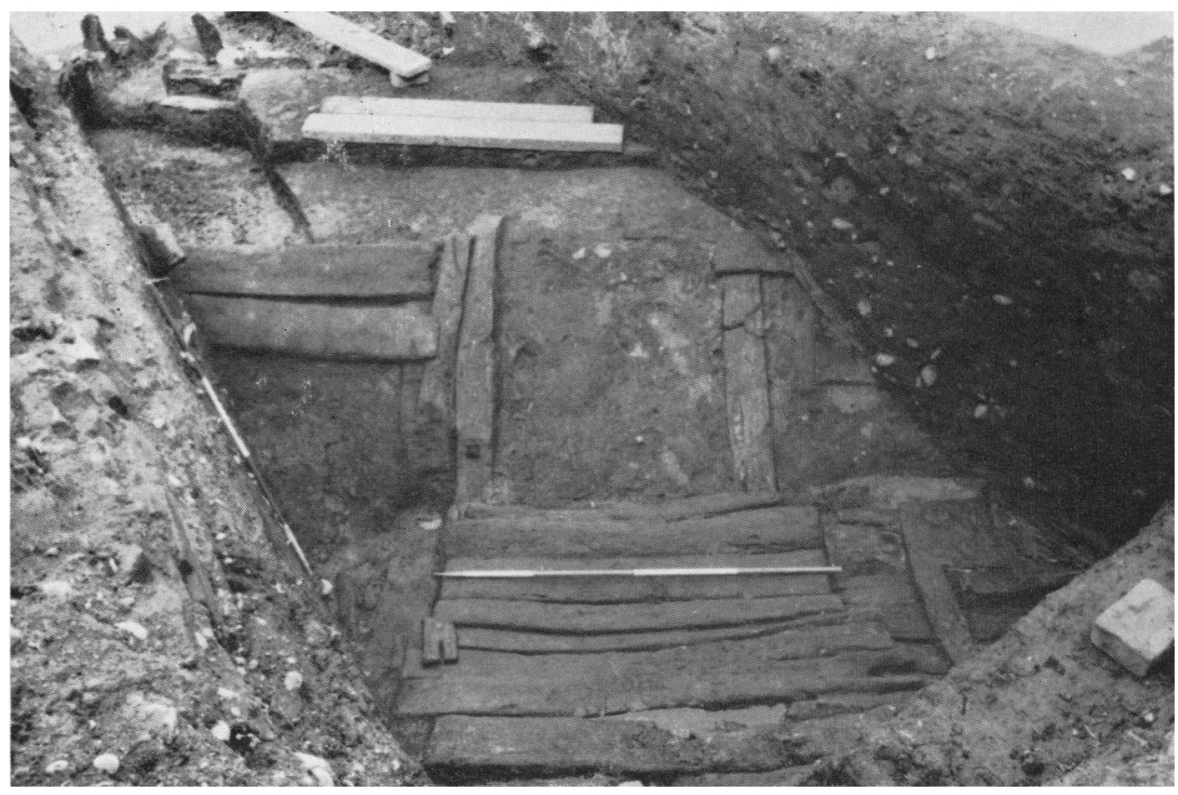

(Photo: D. Charlesworth)

B. Carlisle: the bridge, looking north (p. 410). 


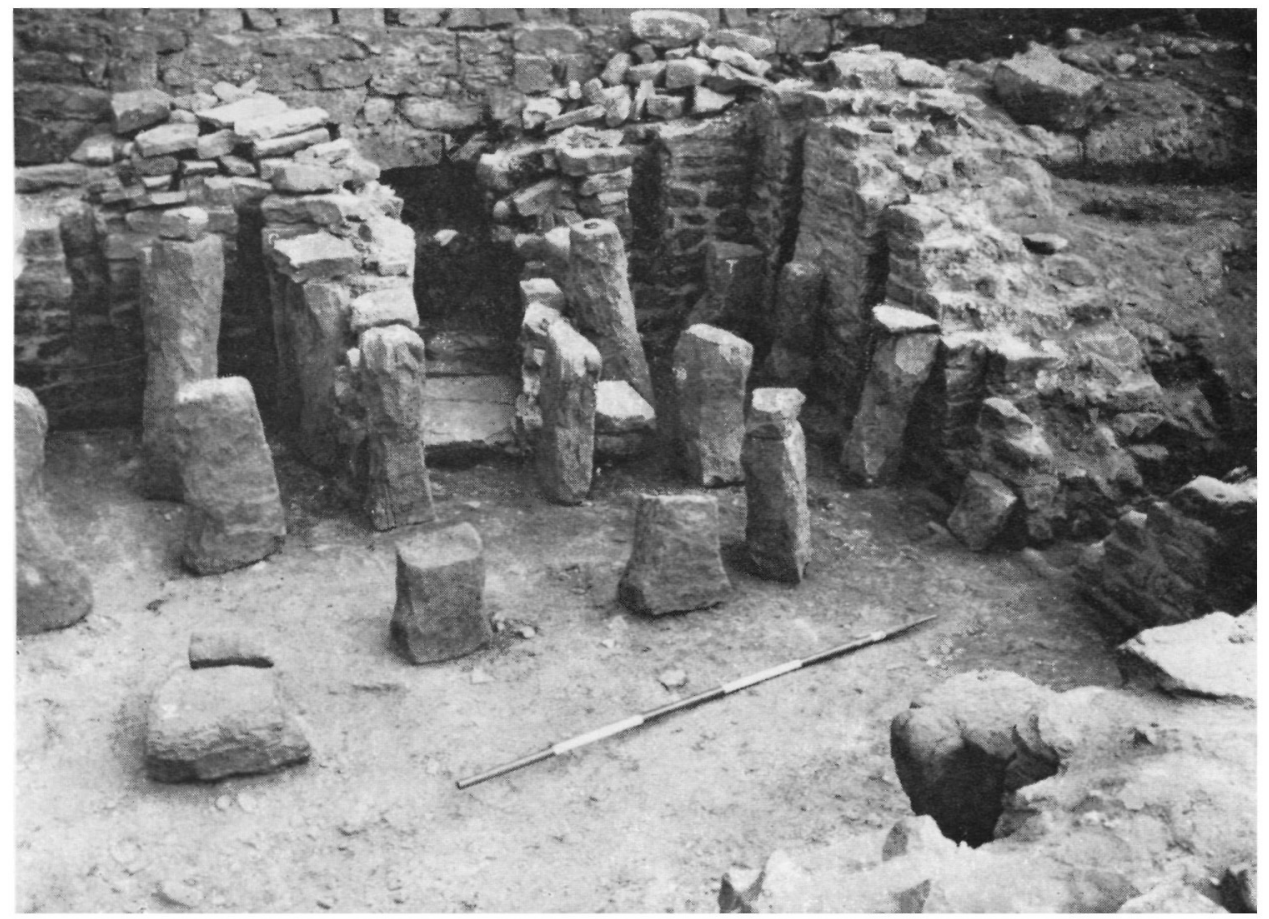

(Rhoto.: by courtesy of Prof. G. D. B. Jones)

Lancaster: the caldarium of Bath-house I. The ditch of the fourth-century Wery Wall is cut through the wall and pilae to the left (p. $4^{18}$ ). 


\section{PLATE XXXVIII}

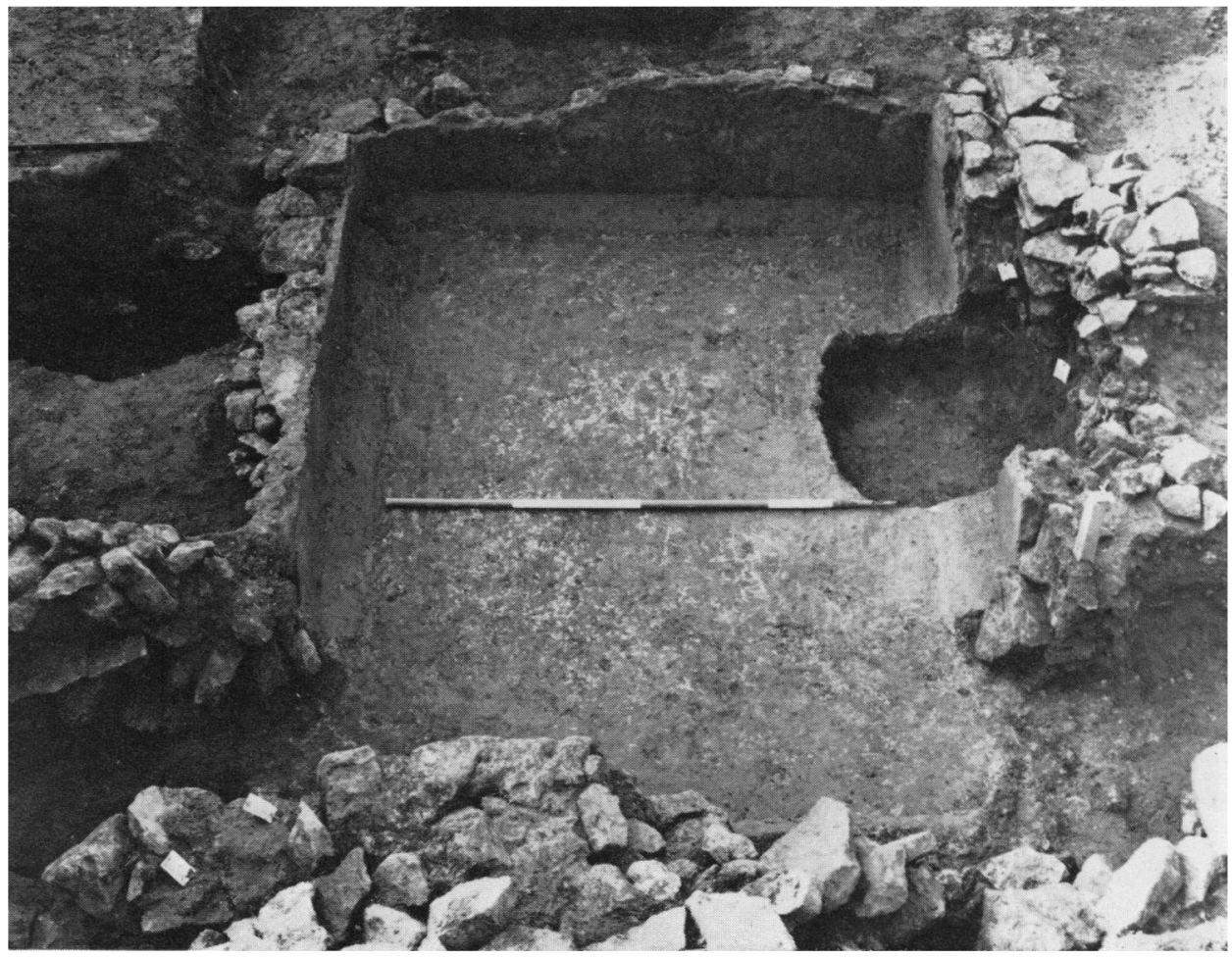

(Photo: H. N. Hawley)

A. Lincoln: Broadgate East: cold plunge-bath or water tank of the second century (p. 421 ).

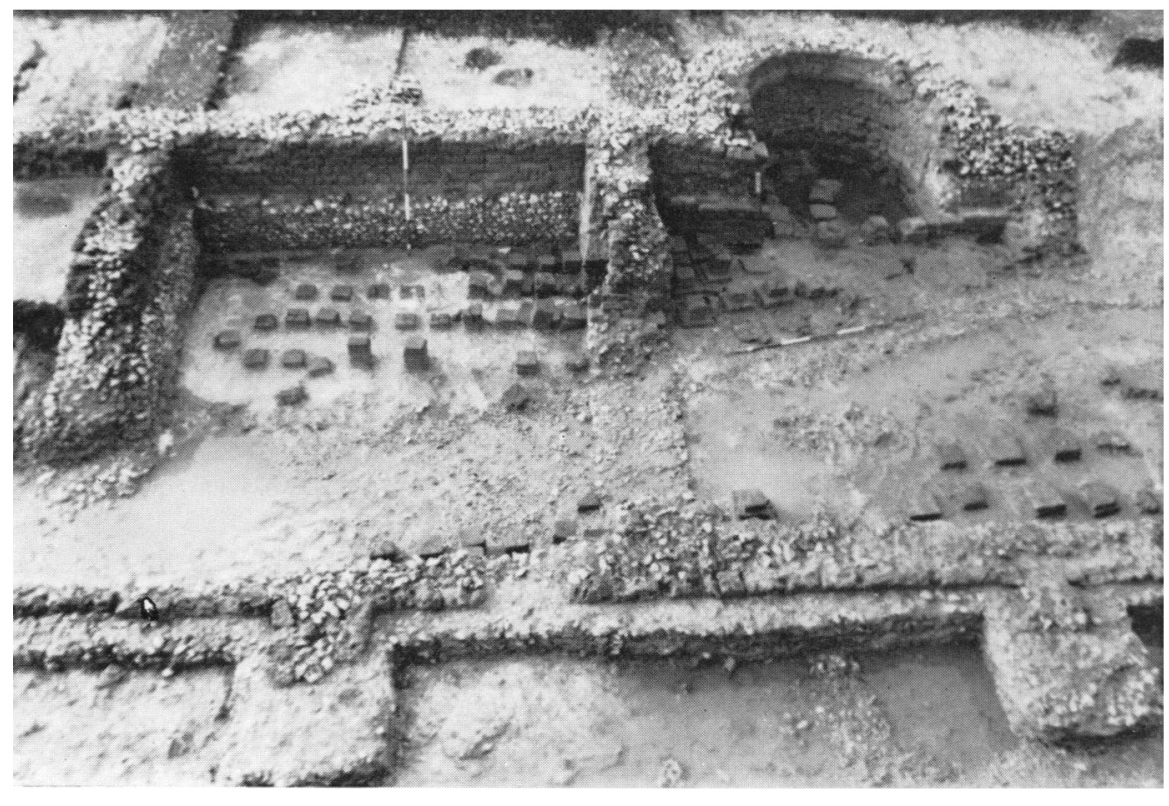

Ploto: C. Partridge

B. Braughing, Herts.: the bath-building looking west showing the tufa lining of the walls. Opus signimum floor of Room I on left, apse of Room 3 on right (p. 437). 


\section{PLATE XXXIX}

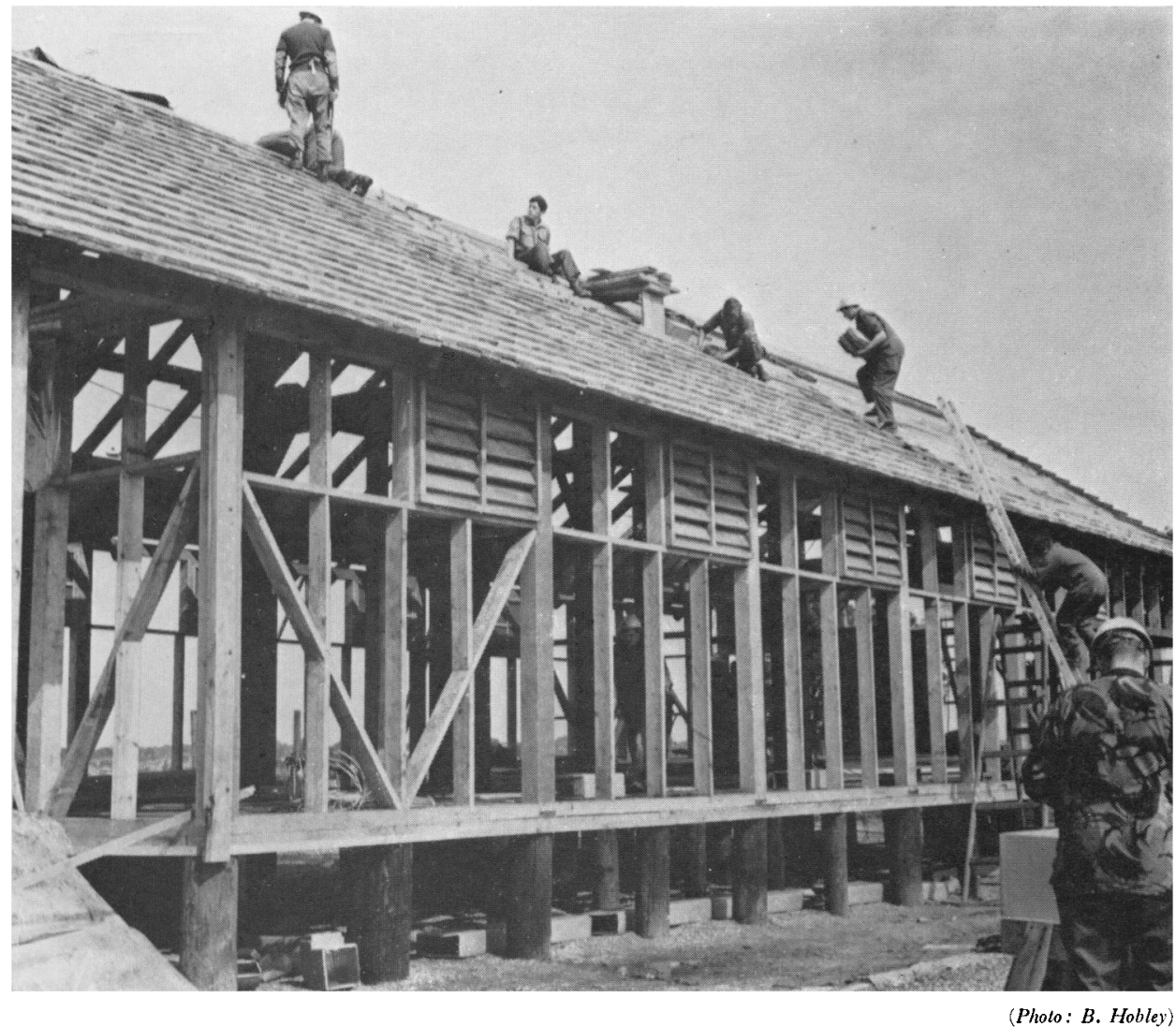

A. Baginton, Warwickshire, The Lunt. Reconstruction of the granary (p. 43I).

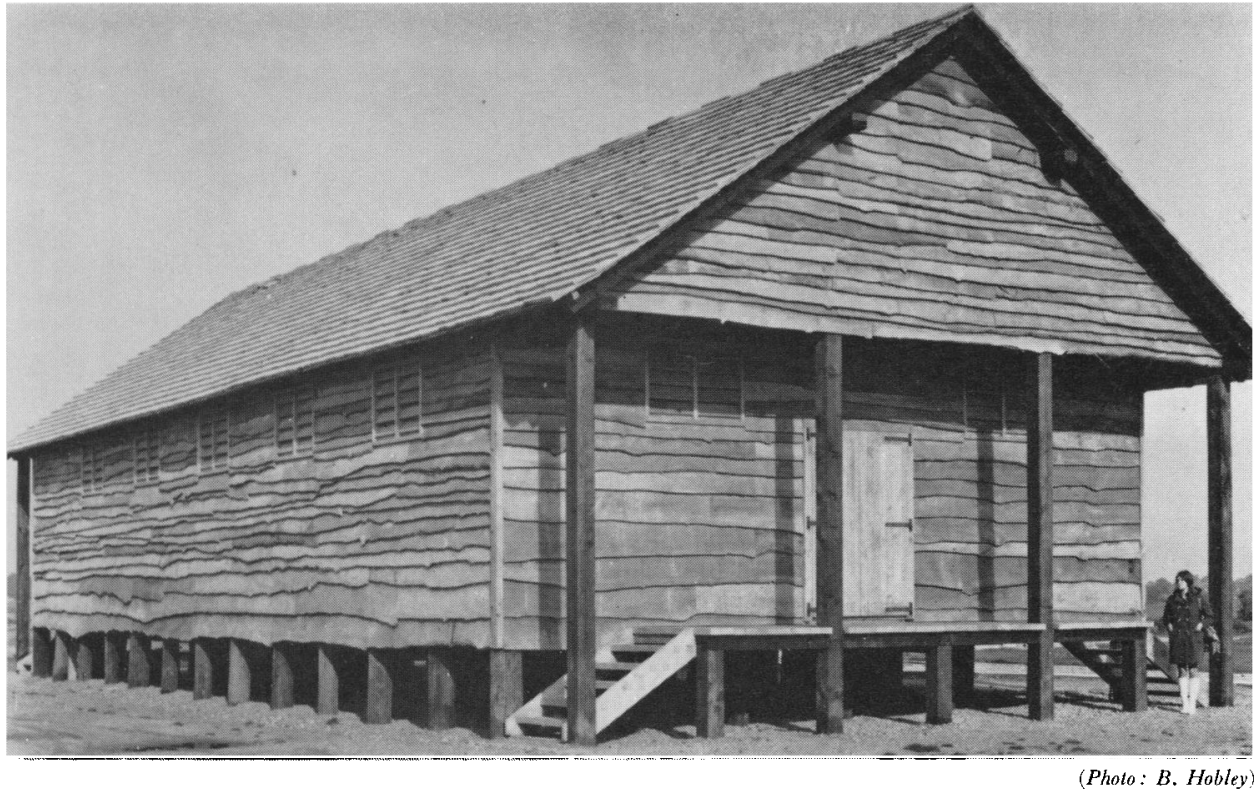

B. Baginton: the reconstructed granary. 
PLATE XL

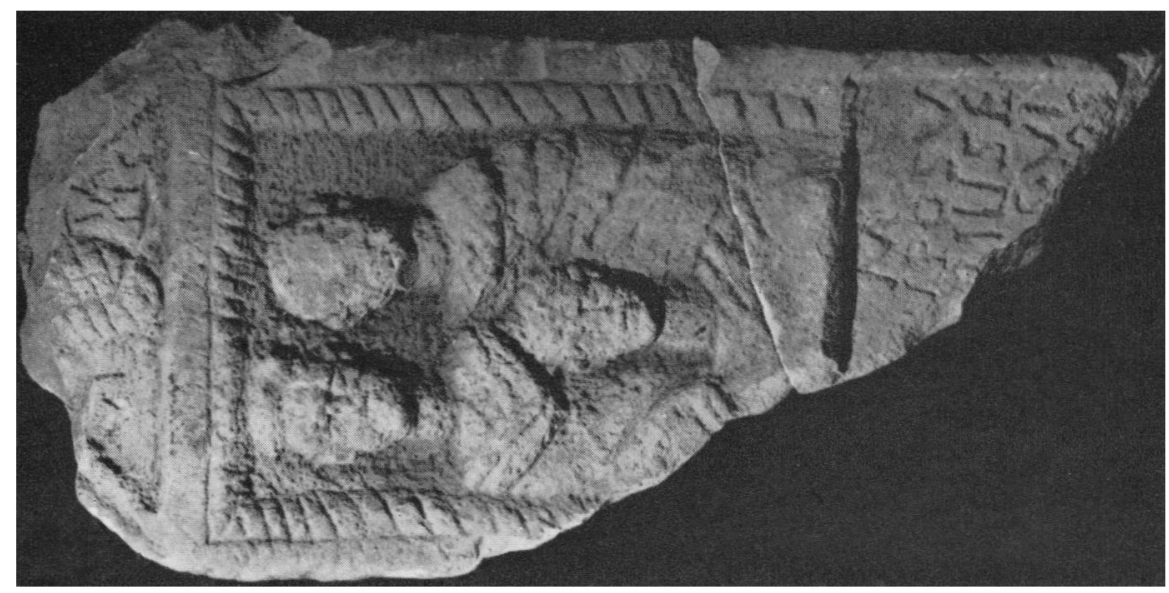

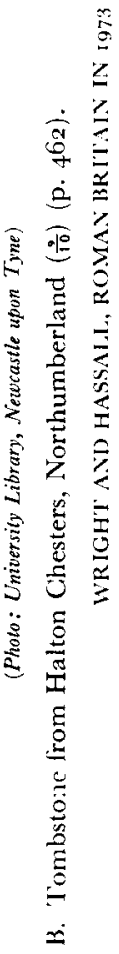

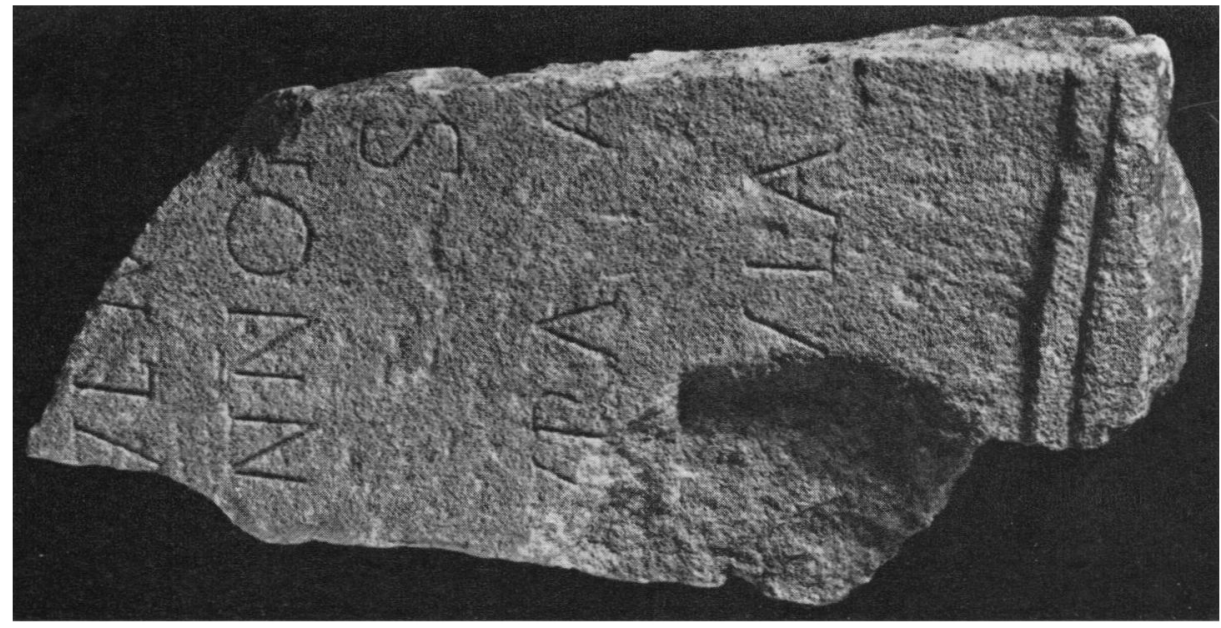




\section{PLATE XLI}
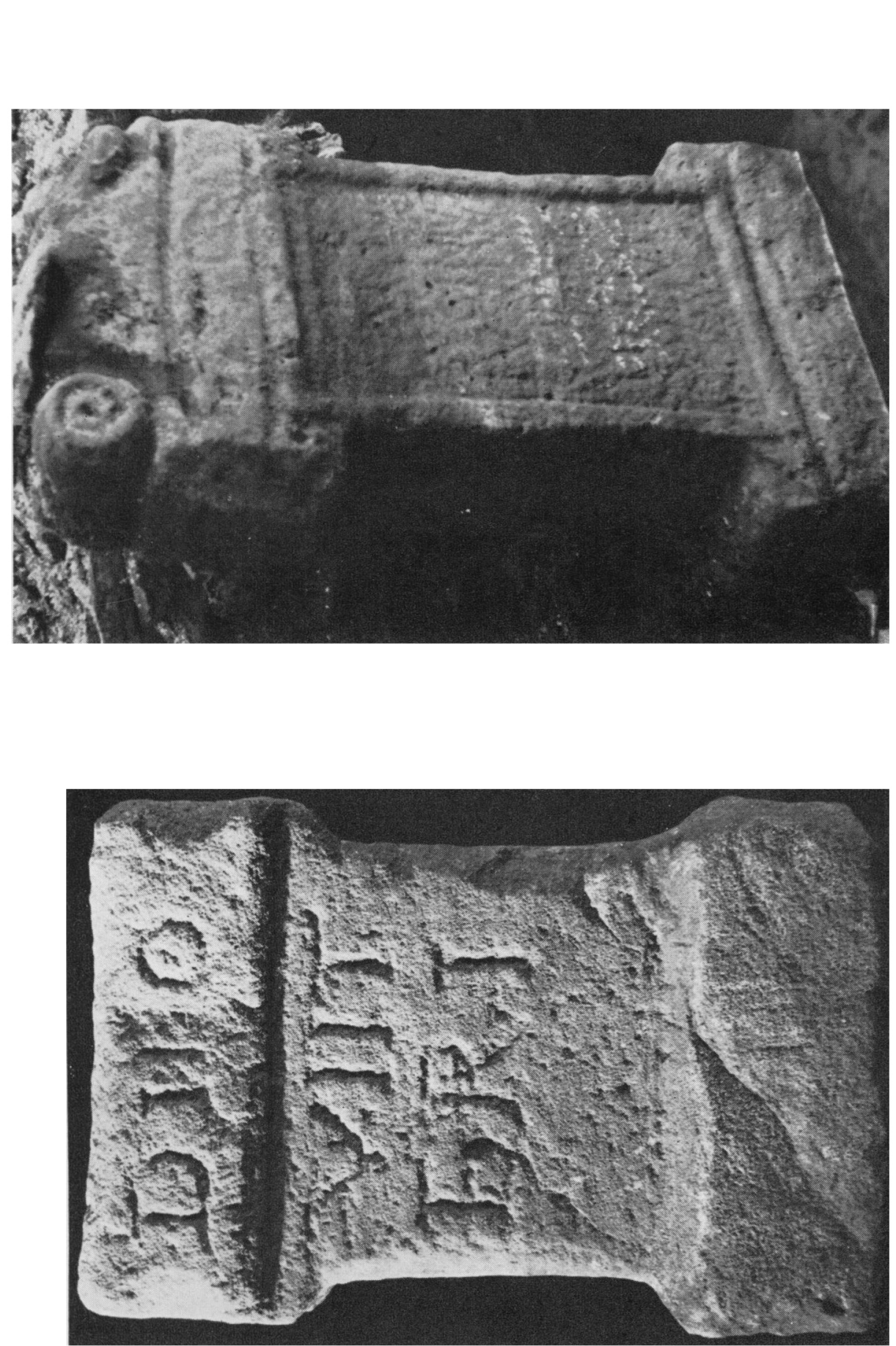


\section{PLATE XLII}

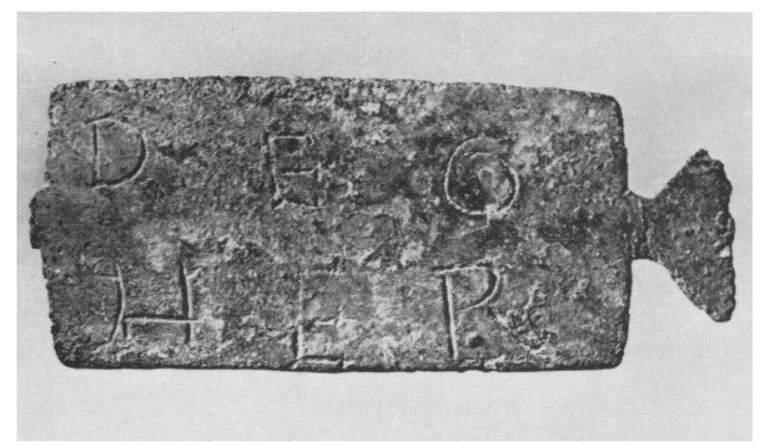

(Photo: P. G. Dorrell)

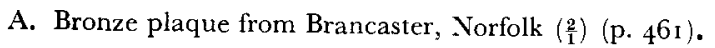

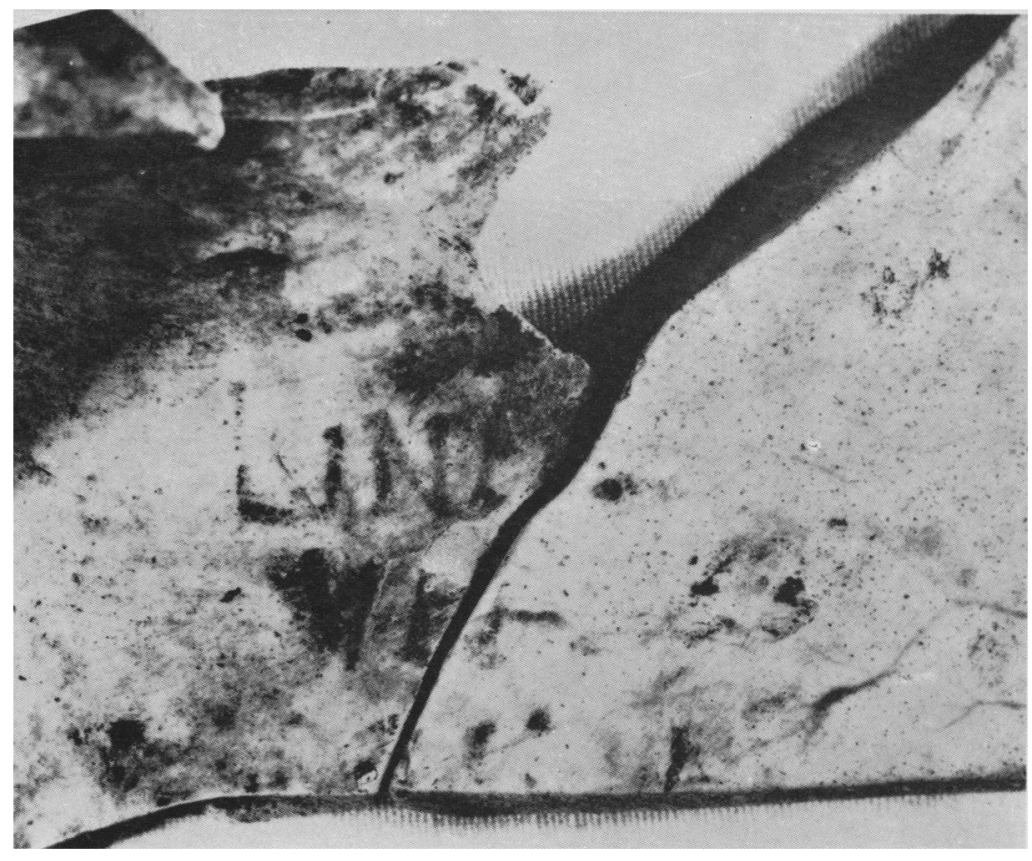

(Photo: Department of Photography, Lnizersity of Tewrastle upron Tine)

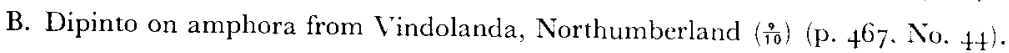




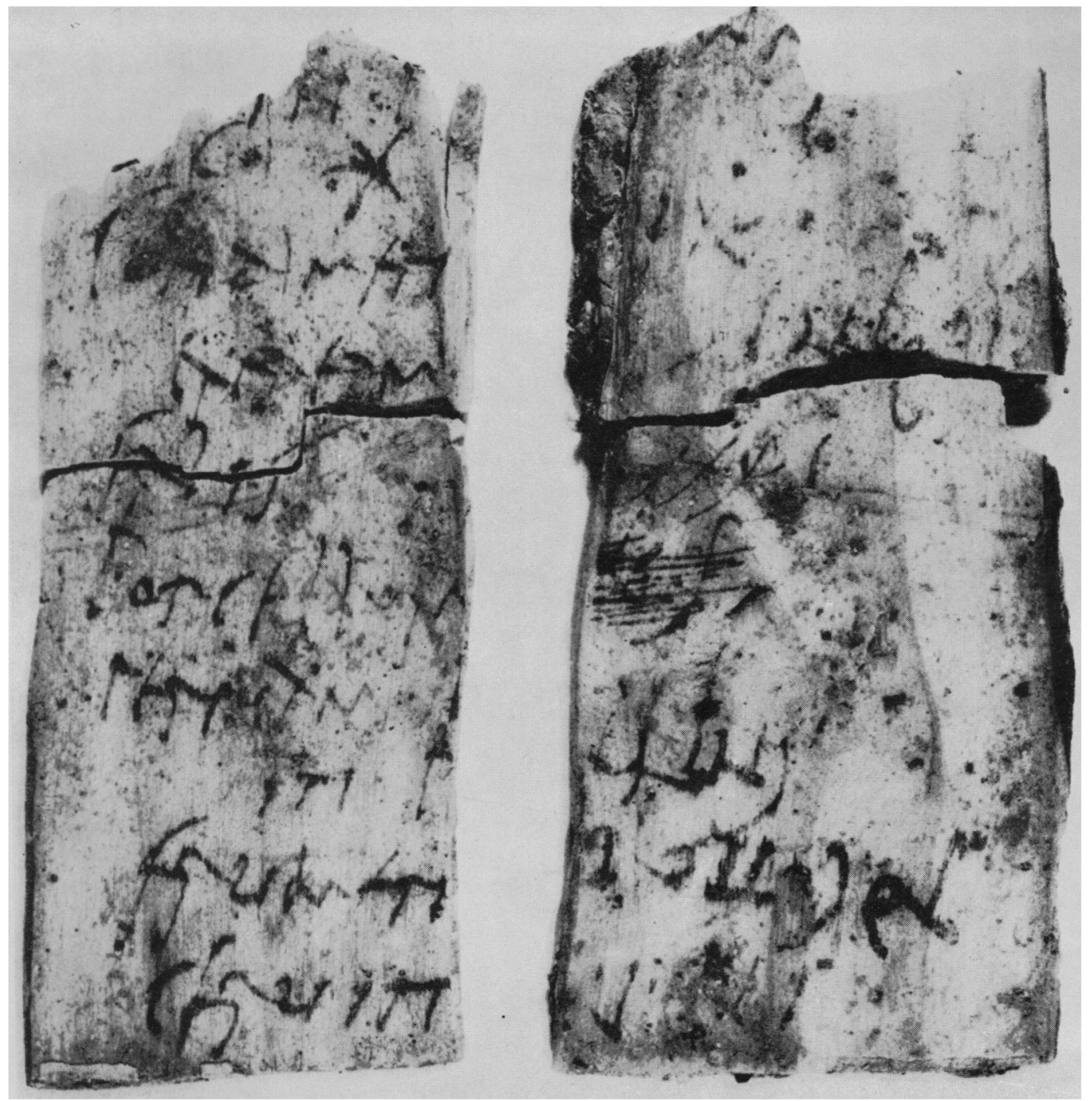

(Photo: Department of Photography, University of Newcastle upon Tyne; copyright reserved)

Wooden tablet No. II from Vindolanda, Northumberland $\left(\frac{2}{1}\right)$ (p. 477). 


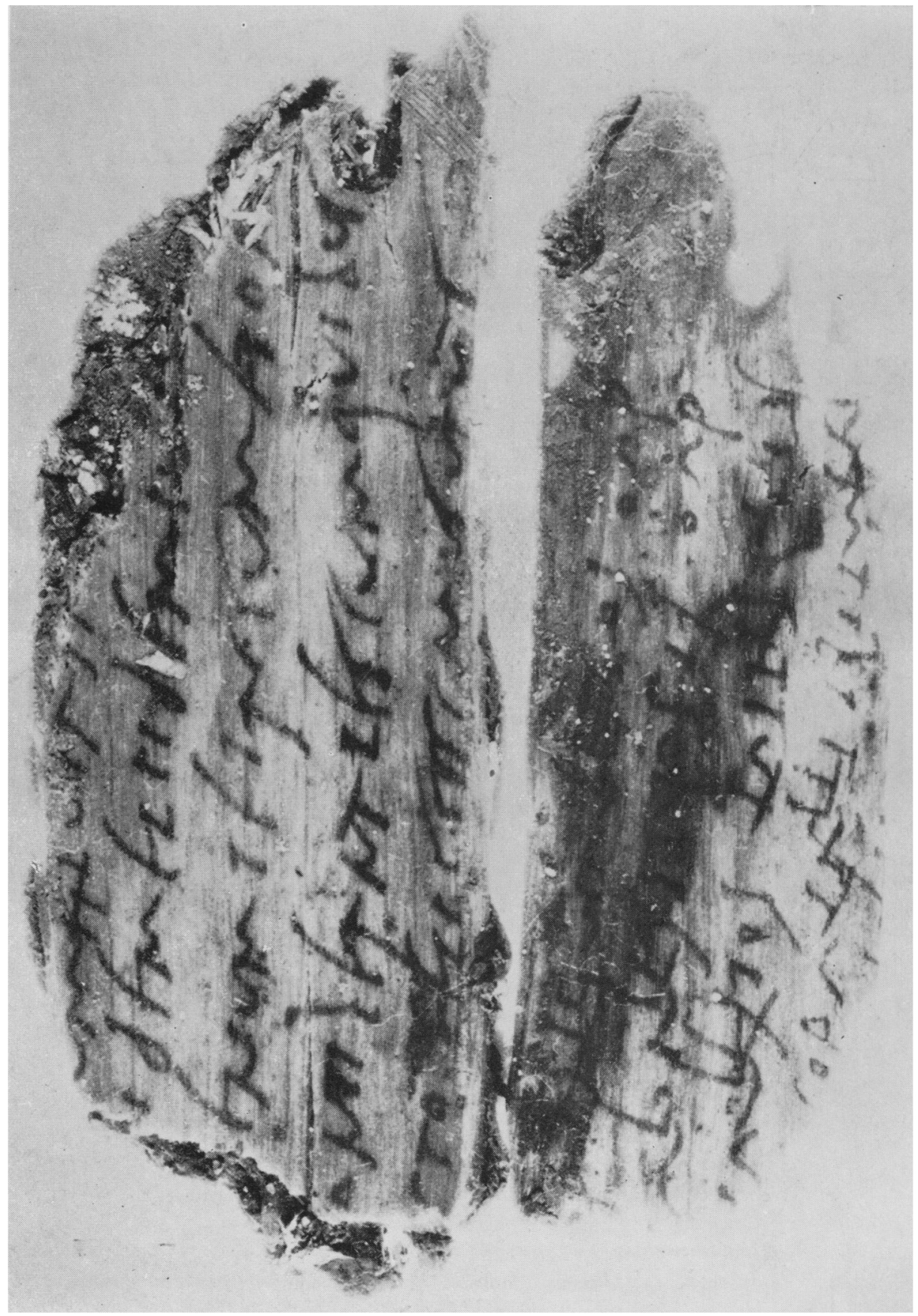

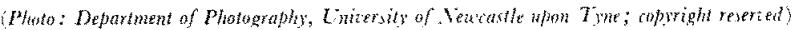
Wooden tablet No. 15 from Vindolanda, Northumberland $\left(\frac{2}{1}\right)(p .474)$. 